\author{
UNIVERSIDADE DE SÃO PAULO \\ FACULDADE DE CIÊNCIAS FARMACÊUTICAS \\ Programa de Pós Graduação em Toxicologia e \\ Análises Toxicológicas \\ Área de Análises Toxicológicas
}

\title{
DETERMINAÇÃO DOS COMPONENTES ALERGÊNICOS DA PROTEÍNA ISOLADA DA SOJA
}

Alvorita Leite Bittencourt

Tese para obtenção do grau de

DOUTOR

Orientadora

Dulcinéia Saes Parra Abdalla

Co-orientadora

Irene Fernandes

São Paulo

2002 
Ficha Catalográfica

Elaborada pela Divisão de Biblioteca e

Documentação do Conjunto das Químicas da USP.

Bittencourt, Alvorita Leite

B624d Determinação dos componentes alergênicos da proteína isolada da soja / Alvorita Leite Bittencourt. -- São Paulo, 2002. $99 p$.

Tese (doutorado) - Faculdade de Ciências Farmacêuticas da Universidade de São Paulo. Departamento de Análises Clínicas e Toxicológicas.

Orientador: Abdalla, Dulcinéia Saes Parra

Co-orientadora: Fernandes, Irene

I. Imunotoxicologia I. T. II. Abdalla, Dulcinéia Saes Parra, orientador III. Fernandes, Irene, co-orientador. 


\title{
DETERMINAÇÃO DOS COMPONENTES ALERGÊNICOS DA PROTEÍNA ISOLADA DA SOJA
}

\author{
Comissão Julgadora \\ Tese para obtenção do grau de \\ DOUTOR \\ Profa. Associada Dra. Dulcinéia Saes Parra Abdalla \\ Orientadora/Presidente \\ Magda Maria Sales Carneiro Sampaio \\ $1^{\circ}$ Examinador \\ Cristina Miuki Abe Jacob \\ $2^{\circ}$ Examinador \\ Sandra Helena Poliselli Farsky \\ $3^{\circ}$ Examinador \\ Silvia Berlanga de Moraes Barros \\ $4^{\circ}$ Examinador
}


"De tudo ficaram três coisas: a certeza de que estamos comę̧ando; a certeza de que é preciso continuar e a certeza de que podemos ser interrompidos antes de terminarmos. Fazer da interrupção um caminho novo; fazer da queda um passo de dança; do medo uma escada; do sonfo uma ponte; da procura um encontro. $\mathscr{E}$, assim, terá valido a pena existir"

Fernando Sabino 
Ao Eduardo, que me acompanfou no percurso, comprecndendo minhas ausências e admirando meu trabalfo. 


\section{AGRADECIMENTOS}

Ao meu marido, pelas palavras de estímulo nas horas difíceis e por me mostrar que os grandes desafios somente são ultrapassados com muita persistência e determinação.

Aos meus filhos Gabriela e Douglas, pelo carinho constante.

À mirıha secretária Sandra, pela tranqüilidade que me proporcionou, cuidando com carinho de minha família.

À minha orientadora Dulcinéia Saes Parra Abdalla, pelo carinho e exemplo de profissionalismo.

À professora Márcia, pela correção ortográfica de meu trabalho e pela grande amizade.

À professora Sílvia Berlanga, pela consideração e pelo exemplo de determinação e entusiasmo diante dos obstáculos a serem ultrapassados.

Às pesquisadoras Irene e Fernanda que me acolheram e estiveram sempre de braços abertos para me ajudar.

Aos colegas de pós-graduação, Patrícia, Eder, Nágila, Isabela, Joelma, Elaine, Simone, Emerson, Edimar, Ednéia, Alessandra e Noeli, que contribuiram de alguma forma com a realização deste trabalho.

Às estagiárias Márcia, Cristina e Flávia pela grande colaboração.

Aos animais, que mesmo involuntariamente, doaram suas vidas, permitindo-nos avançar cientificamente na àrea de Imunotoxicologia.

À CAPES, pelo apoio financeiro. 


\section{ÍNDICE}

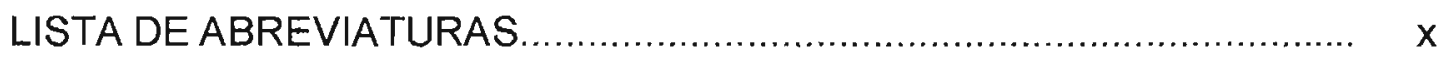

LISTA DE FIGURAS.......................................................................

LISTA DE TABELAS ................................................................ xiv

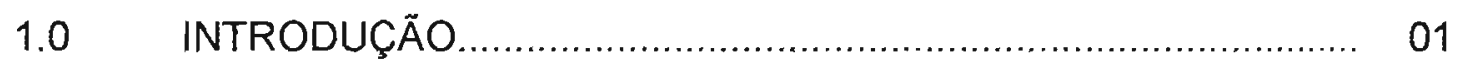

2.0 REVISÃO DA LITERATURA ......................................... 06

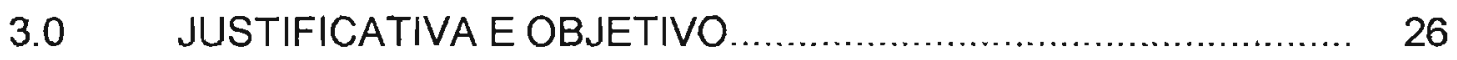

4.0 MATERIAL E MÉTODOS ................................................ 28

4.1 Isolamento das frações protéicas $2 \mathrm{~S}, 7 \mathrm{~S}$ e $11 \mathrm{~S}$ da soja.............. 28

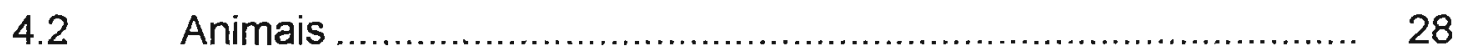

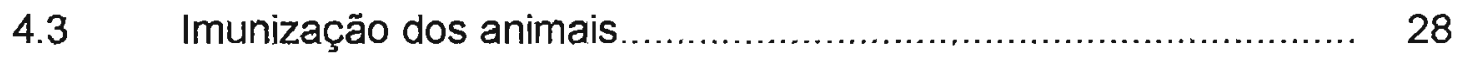

Soros de pacientes....................................................... 30

4.4.1 Extração e purificação da fração 7S da soja............................... 31

4.4.2 Extração e purificação das frações 2S e 11S da soja................. 32

4.5 Avaliação da produção de anticorpos das classes $\operatorname{lgM}$ e $\lg G$ dirigidos contra as frações protéicas $2 S, 7 S$ e $11 S$ da soja, em camundongos

4.6 Teste de Anafilaxia Cutânea Passiva, em ratos......................... 34

4.7 Análise da presença de anticorpos lgE e lgG, reativos às frações protéicas $2 S, 7 S$ e $11 S$, no soro de pacientes alérgicos à soja.

4.8 Produção de Anticorpos Monoclonais................................... 36

4.8.1 Descongelamento e expansão de células de mieloma SP2-O..... 37

4.8.2 Preparo de monocamada de fibroblastos e macrófagos.............. 38

4.8.3 Protocolo de fusão celular ............................................ 38 
4.8.4 Triagem dos clones.................................................. 39

5.8.5 Diluição limitante............................................................. 40

4.8.6 Clonagem e sub-clonagem.dos hibridomas.......................... 40

4.8.7 Isotipagem dos anticorpos monoclonais............................ 41

4.8.8 Produção de ascite em camundongos.................................. 41

4.8.9 Purificação dos anticorpos monoclonais............................... 42

4.8.10 Análise da especificidade dos anticorpos monoclonais.............. 43

4.9 Detecção de proteínas da soja, em produtos comercializados..... 44

4.10 Análise estatística..................................................... 45

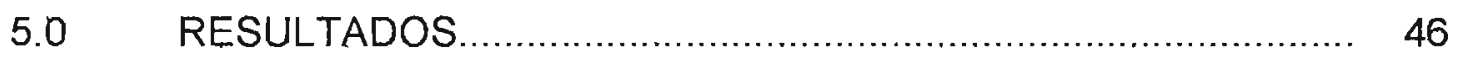

5.1 Avaliação da cinética da produção de anticorpos $\operatorname{lgM}$ e $\lg G$ dirigidos contra as frações protéicas $2 S$, $7 S$ e $11 S$ da soja, em camundongos.

5.2 Avaliação do potencial alergênico das fraçōes protéicas 2S, $7 \mathrm{~S}$ e $11 \mathrm{~S}$ da soja, pelo teste de Anafilaxia Cutânea Passiva.

5.3 Avaliaçăo da presença de anticorpos $\operatorname{lgE}$ e $\lg G$ reativos às frações protéicas $2 S, 7 S$ e $11 S$, no soro de pacientes alérgicos à soja.

5.4 Obtenção de anticorpos monoclonais dirigidos contra as frações protéicas $7 \mathrm{~S}$ e $11 \mathrm{~S}$ da soja.

5.4.1 Clonagem dos anticorpos monocionais direcionados às fraçōes protéicas 75 e 115 da soja.

5.4.2 Isotipagem dos anticorpos monoclonais reativos às frações protéicas $7 \mathrm{~S}$ e $11 \mathrm{~S}$ da soja.

5.4.3 Purificação dos anticorpos monoclonais dirigidos contra as frações protéicas $7 \mathrm{~S}$ e $11 \mathrm{~S}$ da soja.

5.4.4 Avaliação da especificidade dos anticorpos monoclonais, por imunotransferência.

5.4.5 Detecção de proteinas de soja em produtos comercializados. 


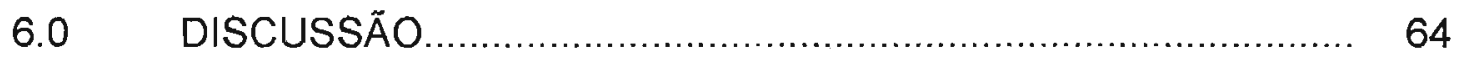

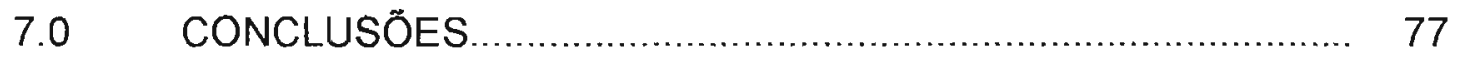

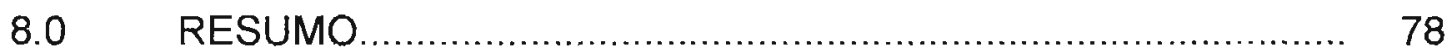

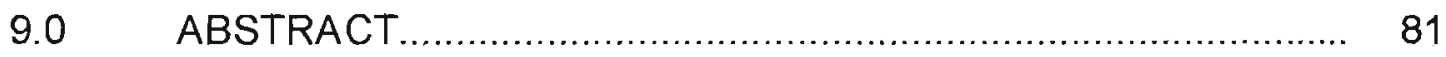

10.0 REFERÊNCIAS BIBLIOGRÁFICAS ...................................... 83

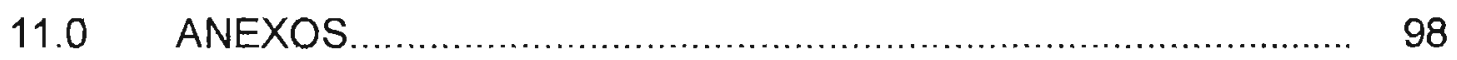

11.1 Tabela de dados clínicos dos pacientes alérgicos à soja e controles.

11.2 Tabela de dados do teste de ELISA, investigando anticorpos IgG, reativos às frações $2 S, 7 S$ e 11 da soja, em pacientes alérgicos e controles

11.3 Tabela de dados do teste de ELISA, investigando anticorpos $\lg \mathrm{E}$, reativos às frações $2 S, 7 S$ e $11 \mathrm{~S}$ da soja, em pacientes alérgicos e controles.

11.4 Soluções e reagentes utilizados................................................ 101

a) Eletroforese em gel de poliacrilamida........................................ 101

b) Ensaio imunoenzimático (ELISA) ........................................... 102

c) Análise por Imunotransferência........................................... 103

d) Produção de anticorpos monoclonais......................................... 103

e) Extração e purificação da fração 7S da soja.................................. 104 


\section{LISTA DE ABREVIATURAS}

\begin{tabular}{|c|c|}
\hline $11 \mathrm{~S}$ & glicinina \\
\hline $2 S$ & $\alpha$ conglicinina \\
\hline $7 S$ & $\gamma$ e $\beta$ conglicinina \\
\hline ACP & anafilaxia cutânea passiva \\
\hline$A E$ & azul de evans \\
\hline CD 154 (CD40L) & receptor de célula T CD4 ${ }^{+}$ \\
\hline CD4 & $\begin{array}{l}\text { marcador de superfície de célula } \mathrm{T} \text { helper, timócito, } \\
\text { monócito e macrófago }\end{array}$ \\
\hline CD40 & $\begin{array}{l}\text { receptor de células } B \text {, macrófagos, células dendríticas e } \\
\text { endoteliais }\end{array}$ \\
\hline CD8 & marcador de superfície de célula T citotóxica e timócito \\
\hline CD80 (B7-1) & $\begin{array}{l}\text { receptor de células dendríticas, células } B \text { ativadas e } \\
\text { macrófagos }\end{array}$ \\
\hline CD86 (B7-2) & $\begin{array}{l}\text { receptor de células } B \text {, monócitos, células dendríticas e } \\
\text { algumas células } T\end{array}$ \\
\hline e.p.m. & erro padrão da média \\
\hline ELISA & ensaio imunoenzimático \\
\hline FCERI & receptor de alta afinidade para $\lg E$ \\
\hline $\mathrm{FC} \varepsilon \mathrm{R} I \mathrm{l}(\mathrm{CD} 23)$ & receptor de baixa afinidade para lgE \\
\hline HAT & histidina, aminopterina e timidina \\
\hline HT & Histidina e timidina \\
\hline i.p. & intraperitoneal \\
\hline IL & interleucina \\
\hline IL4R $\alpha$ & cadeia $\alpha$ do receptor de IL-4 \\
\hline INF- $\gamma$ & interferon $\gamma$ \\
\hline $\mathrm{KDa}$ & quilodaltons \\
\hline $\mathrm{MHC}$ & complexo de histocompatibilidade principal \\
\hline MM & Massa molecular \\
\hline$N F-k B$ & fator nuclear kappa B \\
\hline PBS & tampão fosfato salina \\
\hline PCBs & Bifenilas policlorinatadas \\
\hline
\end{tabular}




$\begin{array}{ll}\text { PEG } & \text { polietilenoglicol } \\ \text { rads } & \text { radiações } \\ \text { RAST } & \text { Teste de radioalergoabsorção } \\ \text { SDS } & \text { dodecil sulfato de sódio } \\ \text { SDS-PAGE } & \text { eletroforese em gel de poliacrilamida } \\ \text { Stat } 6 & \text { transdutor de sinal e ativador de transcrição } \\ \text { TCDD } & 2,3,7,8 \text { tetraclorodibenzo-p-dioxina } \\ \text { Th1 } & \text { célula T helper } 1 \\ \text { Th2 } & \text { célula T helper } 2 \\ \text { TNF- } \alpha & \text { fator de necrose tumoral } \alpha\end{array}$




\section{LISTA DE FIGURAS}

Figura 1 Estrutura quaternária das seis subunidades da glicinina........... 10

Figura 2 Relação entre as diferentes $\beta$ conglicininas e suas subunidades.

Figura 3 Extração e purificação da fração $7 \mathrm{~S}$, a partir do isolado protéico da soja.

Figura 4 Extração e purificação das frações protéicas 2S e 11S, a partir da farinha desengordurada da soja...

Figura 5 Esquema de produção de anticorpos monoclonais.

Figura 6 Avaliação da cinética da produção de anticorpos das classes IgM e IgG dirigidos contra a fração protéica $2 S$ da soja...

Figura 7 Avaliação da cinética da produção de anticorpos das classes $\operatorname{lgM}$ e IgG dirigidos contra a fração protéica 7S da soja.

Figura 8 Avaliação da cinética da produção de anticorpos das classes IgM e IgG dirigidos contra a fração protéica 11 S da soja...

Figura 9 Anafilaxia cutânea passiva induzida pela fração protéica $7 S$, em ratos Wistar.

Figura 10 Avaliação da cinética da produção de anticorpos da classe IgE dirigidos contra a fração $7 \$$ da soja.

Figura 11 Análise sérica de anticorpos da classe IgE dirigidos contra as frações protéicas $2 S$, $7 S$ e $11 S$ da soja, em pacientes alérgicos.

Figura 12 Representação gráfica da curva padrão lgE

Figura 13 Produção de anticorpos da classe IgG reativos às frações protéicas $2 \mathrm{~S}, 7 \mathrm{~S}$ e $11 \mathrm{~S}$ da soja, em pacientes alérgicos.

Figura 14 Clonagem dos anticorpos monoclonais direcionados à fração protéica 7S da soja.

Figura 15 Clonagem do anticorpo monoclonal reativo à fração protéica $11 S$ da soja. 
Figura 16 Avaliação do limiar de reatividade dos anticorpos monoclonais direcionados às frações $7 \mathrm{~S}$ e $11 \mathrm{~S}$ da soja...

Figura 17 Isotipagem dos anticorpos monoclonais reativos às frações protéicas 75 e $11 \mathrm{~S}$ da soja.

Figura 18 Perfil cromatográfico da purificação dos anticorpos monoclonais dirigidos contra as fraçōes protéicas 75 e $115 \mathrm{da}$ soja.

Figura 19 Análise da especificidade dos anticorpos monoclonais reativos às fraçōes $7 \mathrm{~S}$ e 11S, por imunotransferência..............................

Figura 20 Identificação das proteinas de soja em produtos comercializados. 


\section{LISTA DE TABELAS}

Tabela 1 Composição estrutural das frações protéicas 7 e 11 da soja...... 12

Tabela 2 Produtos comercializados à base de soja... 45 


\subsection{INTRODUÇÃO}

A Imunotoxicologia é uma área nova dentro da Toxicologia, surgida no final de 1960 e início de 1970, com a iniciativa de alguns pesquisadores os quais acreditavam que as substâncias químicas pudessem interferir com o sistema imune, trazendo inúmeras conseqüências ao organismo (KOLLER, 2001).

Em 1966, foi descoberto que uma única dose intravenosa de acetato de chumbo aumentou a sensibilidade de ratos às endotoxinas de bactérias gram negativas (SELYE et al., 1966). A confirmação desses dados foi obtida em estudos com galinhas (TRUSCOTT, 1970) e camundongos (RIPPE \& BERRY, 1973) expostos a uma combinação de acetato de chumbo e endotoxinas bacterianas, além de outro trabalho que utilizou acetato de cádmio em ratos expostos à endotoxina da Salmonella enteritidis (COOK et al., 1974). Subseqüentemente, alguns experimentos mostraram que as doses de 10 ou 1000 ppm de acetato de chumbo pode suprimir a resposta imune humoral e que esse xenobiótico reduz os títulos de anticorpos devido ao dano causado em sua síntese (KOLLER et al., 1976).

Outros estudos demonstraram que coelhos alimentados com DDT e Carbaril, individualmente $(4,0 ; 20,0 ; 45,0$ e 150,0 ppm); Aroclor $1254(3,7 ; 20,0$; 45,8 e 170,0 ppm); Carbofuran (0,5;2,5; 9,0 e 20,0 ppm) e Metilparation (0,6; 2,6; 8,5 e 23,0 ) tiveram atrofia do timo (STREET \& SHARMA, 1975) e que $1 \mu \mathrm{g} / \mathrm{kg}$ de 2,3,7,8-tetraclorodibenzo-p-dioxina (TCDD) aumentou a susceptibilidade de camundongos à infecção por Salmonella bern (THIGPEN et al., 1975). Esse estudo foi reconduzido por outros pesquisadores demonstrando que o TCDD 
reduziu a resposta imune secundária em cobaias e induziu uma severa atrofia do timo (MOORE \& FAITH, 1976), concluindo-se que essa substância química pode prejudicar a imunidade mediada por células.

No final da década de 70 , novos investigadores iniciaram pesquisas nessa área (KERKVLIET \& KIMELDORF, 1977; LUSTER et al., 1978; SILKWORTH \& LOOSE, 1978; LAWRENCE et al., 1978; DEAN et al., 1979; HINTON et al., 1979). A partir desses e de outros estudos realizados durante esse período, tornou-se evidente que substâncias químicas, presentes no meio ambiente, podem comprometer a imunidade dos animais. Esses estudos contribuíram para o estabelecimento da disciplina conhecida como Imunotoxicologia.

A Imunotoxicologia ganhou credibilidade quando substâncias químicas, tais como o toxafeno (10, 100 e 200 ppm) (ALLEN et al., 1982), o pentaclorofenol (KERKVLIET et al., 1982), os sais de chumbo e os PCBs (KOLLER et al., 1982) induziram imunossupressão em doses menores do que as que alteram outros índices toxicológicos. Esse perfil revelou que o sistema imune foi realmente um indicador sensivel para detectar efeitos induzidos por substâncias químicas. Entretanto, tornou-se evidente que a imunossupressão pode ser responsável não somente por um aumento na susceptibilidade aos agentes infecciosos, mas, também, por um aumento no risco de desenvolvimento de câncer (TALCOTT et al., 1984; PARNELL et al., 1986; TALCOTT et al., 1990).

O campo da Imunotoxicologia explodiu no final da década de 1980. Muitos novos pesquisadores definiram essa área como sua linha de pesquisa, foram criados programas para treinar imunotoxicologistas, inúmeros ensaios foram desenvolvidos, várias metodologias foram validadas e a pesquisa básica foi 
desenvolvida visando um melhor conhecimento dos mecanismos responsáveis pelo desenvolvimento da imunotoxicologia. Durante esse período, os investigadores descobriram que substâncias químicas podem comprometer uma ou mais vias do sistema imunológico, identificando alterações em estruturas celulares, membranas, superfície de moléculas e/ou uma variedade de receptores (KOLLER, 2001).

Uma das ferramentas mais importantes utilizadas em imunotoxicologia é a análise de citocinas, moléculas responsáveis pela regulação de inúmeros processos, incluindo imunidade, inflamação, apoptose e hematopoiese. O perfil da produção de citocinas pode fornecer uma informação importante sobre a resposta imunológica, tais como as fases de indução e elicitação de várias hipersensibilidades, incluindo alergia. Nesse contexto, sabe-se que o tipo de ensaio utilizado depende da estrutura do laboratório de pesquisa e do tipo de informação desejada. Os melhores ensaios, atualmente em uso, incluem os bioensaios (células, tecidos isolados ou animais), imunoensaios (ensaio imunoenzimático $[E L I S A]$ e radioimunoensaio $[R \mid A]$ ), técnicas de biologia molecular (reação da cadeia de polimerase [PCR], transcrição reversa competitiva [RT-PCR], ensaio de proteção da RNase etc.) e citometria de fluxo. Cada um desses ensaios mostram vantagens e desvantagens e nenhum deles é ideal para todas as aplicações (HOUSE, 2001).

Desde que muitas substâncias químicas têm sido avaliadas em ratos para propósitos farmacêuticos e toxicológicos, em um determinado período utilizou-se esse animal como modelo para imunotoxicologia. No entanto, a imunologia foi rapidamente avançando, usando camundongos como o animal de escolha e, 
posteriormente, foram sendo realizados inúmeros estudos na espécie humana. Os dados coletados de seres humanos, foram obtidos por intermédio de investigações onde os indivíduos foram expostos ocupacionalmente aos xenobióticos, ambientalmente ou por acidente, e via células humanas e tecidos expostos às substâncias químicas in vitro. Por outro lado, há necessidade em se delinear estudos epidemiológicos, retrospectivos ou prospectivos para melhor entender o potencial imunotóxico dos xenobióticos na espécie humana (KOLLER, 2001).

Com base nos dados acima relacionados, fica evidente a importância do estudo do sistema imunológico como órgão alvo de toxicidade dos xenobióticos. Esses agentes podem ser ingeridos acidentalmente ou não e podem estar presentes no ambiente de trabalho, no meio ambiente e em alimentos, causando vários efeitos adversos, tais como imunodepressão, imunoestimulação, hipersensibilidade e autoimunidade.

Com relação à hipersensibilidade, a imunotoxicologia da alergia às proteínas, tem assumido uma grande importância, com a expansão do uso de enzimas na indústria de alimentos e com o desenvolvimento de plantas transgênicas que são compostas de proteínas diferentes, provenientes de outras origens, aumentando o risco de alergenicidade a esses produtos. Por exemplo, a albumina 2S, que é um alérgeno presente na castanha do Brasil, foi geneticamente introduzida na soja. Sabe-se entretanto, que essa proteína causa reações alérgicas em indivíduos sensíveis e que o soro de oito, entre 9 pacientes alérgicos à castanha, têm os testes de RAST (Teste de radioalergoabsorção) e Imunotransferência positivos à soja geneticamente modificada (KIMBER et al., 1997; NORDLEE et al., 1998). Nesse contexto, inúmeros estudos têm sido 
desenvolvidos para identificar e caracterizar o potencial alergênico das proteínas, por intermédio das análises séricas das imunoglobulinas $\lg G$ e $\lg E$, como marcadores de hipersensibilidade alimentar, Imunotransferência, Prick test etc. (DEARMAN \& KIMBER, 2001; ZAR et al., 2001; CHATCHATEE et al., 2001).

Sabendo-se que as leguminosas são constituídas de grande quantidade de proteínas, as quais estão implicadas como responsáveis pelo desenvolvimento de reaçōes alérgicas (SICHERER et al., 2000), o presente estudo foi direcionado para investigar a alergenicidade das proteínas da soja, tentando esclarecer qual das frações protéicas é a mais alergênica. Para tanto, foram padronizadas diferentes metodologias in vitro e realizados experimentos em roedores. Em virtude da expectativa dos consumidores, com relação à segurança na obtenção de alimentos isentos de alérgenos, foram produzidos anticorpos monoclonais com o propósito de padronizar um ensaio imunoenzimático para detectar as proteínas da soja em produtos industrializados, que poderá servir como controle de qualidade na indústria de alimentos. 


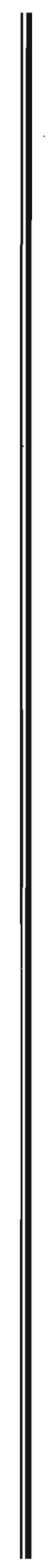

2.0 Revisão da Literatura 


\subsection{REVISÃO DA LITERATURA}

\subsection{Proteínas da soja}

A soja é um vegetal de cor amarela, proveniente da China, que pertence à família das leguminosas. Ela constitui a base da dieta de humanos e animais em muitos países orientais, devido a seu alto valor nutricional e baixo custo.

Além do valor protéico (48 a 50\%), a soja também contém lipídeos (20\%); água (4-10\%); minerais, tais como: ferro, cobre, manganês, cálcio e potássio; vitaminas, assim como: tiamina (B1) e riboflavina (B2); fósforo e outros componentes denominados de fatores antinutricionais, tais como: inibidores de protease, compostos fenólicos, lecitina, saponinas, fitato e outros (GARCIA et al., 1997).

Entre as diferentes formas de aproveitamento da soja, cita-se a obtenção do óleo, que pode ser por prensagem ou extração, com a utilização de solventes. Como resultado desse processo, obtém-se, além do óleo, uma mistura de cascas e flocos de soja desengordurados, contendo em média $44 \%$ de proteína. Após a extração do óleo, tem-se o alimento desengordurado e o processamento dessa mistura pode ser feito por tamizações sucessivas e controladas, resultando em outros produtos intermediários como a farinha desengordurada de soja e farelo, que podem ser aplicados com diferentes finalidades alimentícias. A partir dos flocos de soja desengordurados, pode-se aumentar a concentração protéica ao se remover a porção de carboidratos solúveis, como a rafinose e estaquiose, melhorando a qualidade do produto, antes de disponibilizá-lo para consumo. Após essa remoção, o produto passa a ser denominado de concentrado protéico de soja que deve possuir no mínimo $70 \%$ de proteína do seu peso seco. Os denominados 
isolados protéicos, são obtidos a partir dos flocos desengordurados de soja, que tratados com solventes alcalinos $(\mathrm{pH} 9,0)$, aquecidos a $50-55^{\circ} \mathrm{C}$ e acidificados em $\mathrm{pH} 4,5$, produzirão o soro de soja e o precipitado protéico com $90 \%$ de proteína. $\mathrm{A}$ proteina texturizada de soja ( $20 \%$ de proteína) pode ser conseguida por extrusão, sendo este o produto freqüentemente utilizado em mistura com proteína de origem animal para produção de alimentos cárneos (SNYDER \& KNOW, 1987).

A utilização da soja, como fonte alimentar no mundo ocidental, passou a ter grande importância a partir dos relatos das análises físicas e químicas da soja e de seus componentes, na década de 60 . Com os trabalhos de vários autores, o interesse por esse vegetal aumentou consideravelmente, pois passou a ser mais conhecido e utilizado, uma vez que a soja era uma fonte de proteínas vegetais com baixo teor de gorduras e de cultivo relativamente fácil e preço baixo. Além dessas qualidades, o interesse pela soja aumentou quando, mais recentemente, foram publicados trabalhos sobre o uso da soja na prevenção de diversas doenças como obesidade, diabetes, hipercolesterolemia, câncer, osteoporose, doenças cardíacas e renais e muitas outras (KEETON, 1991; HENLEY et al., 1992; ISHII \& YAMAGUCHO, 1992). Foi, também, relatado um componente da soja que tem ação inibidora de uma enzima conversora da angiotensina I, com uma importante função reguladora da pressão sangüínea e controle do balanço hídrico (GARCIA et al., 1997).

Embora os atributos nutricionais da soja sejam reconhecidos e aproveitados em vários alimentos, o interesse industrial na sua utilização está mais ligado às notáveis propriedades funcionais de suas proteínas. Essas propriedades funcionais (solubilidade, viscosidade, adesividade, capacidade de formação de 
fibras, de formação e estabilização de emulsões, de promoção ou controle da absorção de gorduras, de absorção e retenção de água, de geleificação, de retenção de aromas, de formação de massa, de aeração e controle de cor), podem ser definidas como as propriedades físico-químicas das proteínas responsáveis por seu comportamento durante o preparo, processamento e armazenamento de alimentos, de forma a conferir-lhe algumas características desejáveis. É graças à esta gama de propriedades funcionais que os derivados de soja, tais como a farinha, os concentrados e os isolados protéicos, encontram aplicação em inúmeros alimentos (SAMPSON \& MCCASKILL, 1985; BISHOP et al., 1990).

As fórmulas de soja comercializadas, contêm proteína de soja purificada. A gordura é uma mistura de óleos vegetais e os carboidratos são representados por maltodextrinas, amido de milho ou sacarose. Todas as fórmulas da proteína de soja são livres de lactose, reforçadas com L-metionina e adicionadas de taurina, carnitina e ferro. Muitos alimentos como cucas, biscoitos, sorvetes, sobremesas e bebidas podem ser feitos com fórmulas de soja, oferecendo assim, uma dieta variada às crianças que utilizam esse alimento (BUSINCO et al., 1992).

Foi observado que crianças nascidas a termo e que utilizam em sua alimentação fórmulas de soja, têm um crescimento normal, status nutricional protéico e mineralização óssea normais (JUTO \& WINBERG, 1978; NAIDOO et al., 1981; KOHLER et al., 1984; STEICHEN \& TSANG, 1987), além de não apresentarem nenhuma anormalidade imunológica ou aumento da morbidade devido à infecções (ZOPPI et al., 1983; BUSINCO et al., 1990). Entretanto, há registros na literatura que a prevalência de concomitante hipersensibilidade à soja 
na alergia ao leite de vaca está entre $0 \%$ e $63 \%$, com altos niveis nas síndromes de enterocolite/enteropatia não associadas à IgE (VAN SICKLE et al., 1985; CANTANI et al., 1990; BOCK \& ATKINS, 1990; RAGNO et al., 1993; BURKS et al., 1994; HARIKUL et al., 1995). Sabe-se no entanto, que a verdadeira prevalência da alergia à soja, em documentada alergia ao leite de vaca, não está ainda estabelecida (ZEIGER et al., 1999).

Com base nesses dados da literatura é possivel sugerir que os produtos de soja, que contêm grandes quantidades de proteínas, como por exemplo a farinha, o concentrado e o isolado protéico de soja, podem causar reações alérgicas em indivíduos sensiveis (KNITUNEM et al., 1975; JAKOBSSON \& LINDBERG, 1979; SHIBASAKI et al, 1980; SAMPSON \& MCCASKILL, 1985; BISHOP et al., 1990; HERIAN et al., 1990).

É bem conhecido que a soja é constituída de grande quantidade de proteínas, em torno de $50 \%$, sendo classificadas em três tipos: proteínas envolvidas no metabolismo (fosfodiesterases, $\beta$ amilase, lactato desidrogenase, etc.), proteinas estruturais e glicoproteínas (proteínas de membrana, cromossomais e ribossomais) e proteínas de estoque, que embora estejam em alta concentração, não possuem atividade biológica (GARCIA et al., 1997).

As proteínas de estoque correspondem a $85 \%$ do total de proteínas da soja e são todas globulinas. Baseado em seus coeficientes de sedimentação, por ultracentrifugação, essas proteínas são denominadas de 11S (glicinina), 7S ( $\beta$ e $\gamma$ conglicinina), 2S ( $\alpha$ conglicinina) e globulinas 9S e $15 \mathrm{~S}$. 
A proteína que está em maior quantidade na soja é a 11S, com peso molecular entre 300 e $350 \mathrm{KDa}$, formada por cadeias polipeptídicas ácidas e básicas, representando $40 \%$ do total de proteínas de estoque.

A estrutura quaternária da $11 S$ é composta de doze subunidades, formando dois hexâmeros idênticos (YAMAUCHI et al., 1991). Três das subunidades do hexâmero têm uma natureza ácida (MM 37 a $40 \mathrm{KDa}$ ) e estão presentes em 40 a $50 \%$, enquanto os outros três são componentes básicos (MM 19,9 a $20 \mathrm{KDa}$ ) representando 50 a 60\% (ARRESE et al., 1991; YAMAUCHI et al., 1991).

As cadeias polipeptídicas são unidas por pontes dissulfeto e de hidrogênio, as quais podem ser quebradas pela uréia, por ácidos ou bases fortes, pelo calor e pelo dodecil sulfato de sódio (SDS) (SNYDER \& KNOW, 1987).
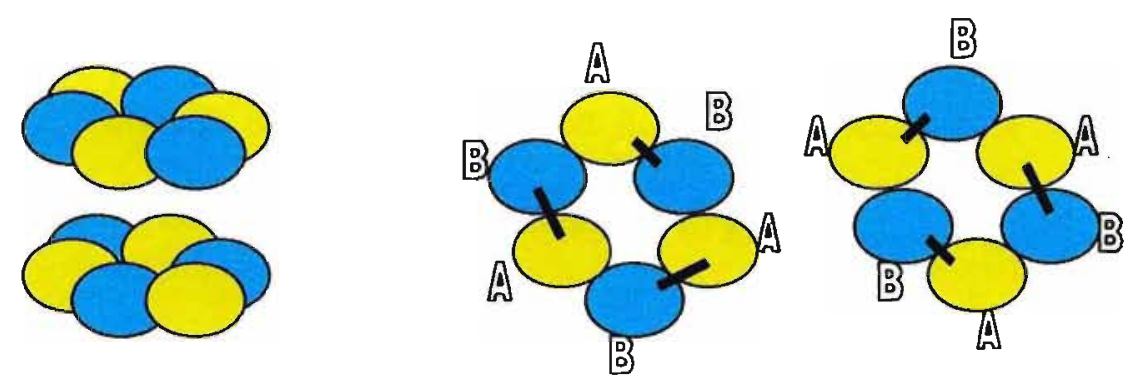

Figura 1 - Estrutura quaternária das seis subunidades da fração protéica $11 \mathrm{~S}$ da soja.

A e B - Cadeias polipetídicas ácidas e básicas, respectivamente (SNYDER \& KNOW, 1987).

A $\beta$ e a $\gamma$ conglicinina (MM 180-210 KDa e 105-150 KDa) representam, respectivamente, $28 \%$ e $3 \%$ do total das proteínas de estoque. A proteína $7 \mathrm{~S}$ é 
uma glicoproteína trimérica que compreende três subunidades: $\alpha$ (PM 57 a 76 KDa), $\alpha^{\prime}(P M 57$ a 83 KDa) e $\beta$ (PM 42 a 53 KDa) presentes na soja em 39,4 $44,6,24,6$ - 31,6 e $28,7-33,5 \%$, respectivamente.

Alguns estudos têm registrado que a $\beta$ conglicinina possue em torno de nove suburidades (KOSHIYAMA, 1968), porém é geralmente aceito que há, apenas, três subunidades $\left(\alpha, \alpha^{\prime}\right.$ e $\beta$ ) combinadas ao acaso, formando diferentes tipos de $\beta$ conglicinina (Figura 2).
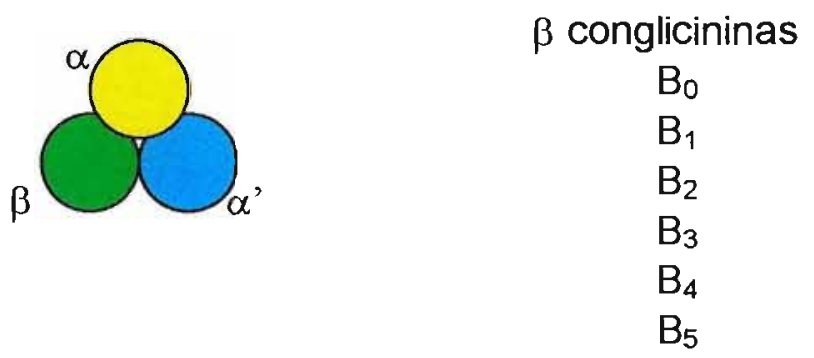

$$
\begin{aligned}
& \text { Subunidades } \\
& \qquad \begin{array}{l}
3 \beta \\
1 \alpha^{\prime} \text { e } 2 \beta \\
1 \alpha \text { e } 2 \beta \\
1 \alpha, 1 \alpha^{\prime}, 1 \beta \\
2 \alpha, 1 \beta \\
2 \alpha, 1 \alpha^{\prime}
\end{array}
\end{aligned}
$$

Figura 2 - Relação entre as diferentes $\beta$ conglicininas e suas subunidades ou estrutura quaternária (SNYDER \& KNOW, 1987).

Por outro lado, a 2S é uma proteína monomérica, com um PM em torno de $21 \mathrm{KDa}$ e representa apenas $13,8 \%$ das globulinas da soja. Na Eletroforese em gel de poliacrilamida (SDS-PAGE), a $2 S$ migra de forma semelhante aos inibidores de tripsina, entretarito estes podem ser distinguidos imunoquimicamente (CATSIMPOLAS \& EKENSTAM, 1969). Além disso, é citado na literatura que a maioria desses inibidores são removidos por germinação (SAVELKOUL et al., 1992; LIENER, 1994) ou tratamento térmico durante o processamento (HUGUES et al., 1994). 
Quando a força iônica é ao redor de $0,1 \mathrm{M}$, a $\beta$ conglicinina, que é o principal componente da fração $7 S$, dimeriza, aumentando o pico correpondente à $9 S$ na ultracentrifugação. De forma semelhante, a fração $11 \mathrm{~S}$ é capaz de formar polímeros com ligações dissulfeto, havendo indícios de que a globulina 155 seja um polímero da globulina 11S, devido a dificuldade em separar essas duas proteínas (SNYDER \& KNOW, 1987; GARCIA et al., 1997). A Tabela 1 mostra a composição de aminoácidos das principais frações protéicas da soja.

Tabela 1 - Composição de aminoácidos (\% por $100 \mathrm{~g}$ de proteínas) das principais globulinas da soja (GARCIA et al., 1997).

\begin{tabular}{|c|c|c|c|c|c|c|c|c|c|c|c|c|c|c|c|c|c|c|c|c|c|}
\hline \multicolumn{2}{|c|}{$\begin{array}{l}\text { Prote- } \\
\text { inas }\end{array}$} & Trp & Lys & His & Arg & Asp & Thr & Ser & Glu & Pro & Gly & Ala & Cys & Val & Met & lle & Leu & Tyт & Phe & $\begin{array}{c}\text { Amô } \\
\text { nia }\end{array}$ & $\begin{array}{l}\text { Açú } \\
\text { car }\end{array}$ \\
\hline \multirow{2}{*}{$7 S$} & $\beta$ & 0.3 & 7.0 & 1.7 & 8.8 & 14.1 & 2.8 & 6.8 & 20.5 & 4.3 & 2.9 & 3.7 & 0.3 & 5.1 & 0.3 & 6.4 & 10.3 & 3.6 & 7.4 & 1.7 & 4.6 \\
\hline & $\gamma$ & 0.7 & 6.8 & 2.8 & 6.3 & 10.0 & 4.2 & 6.5 & 17.5 & 5.9 & 6.1 & 4.7 & 1.1 & 6.4 & 1.4 & 4.4 & 7.6 & 2.1 & 5.5 & - & 2.9 \\
\hline
\end{tabular}

\begin{tabular}{|c|l|l|l|l|l|l|l|l|l|l|l|l|l|l|l|l|l|l|l|l|}
\hline $11 S$ & 1.5 & 5.7 & 2.6 & 8.9 & 13.9 & 4.1 & 6.5 & 25.1 & 6.9 & 5.0 & 4.0 & 1.7 & 4.9 & 1.3 & 4.9 & 8.1 & 4.5 & 5.5 & 1.6 & 0.8 \\
\hline
\end{tabular}

Os métodos mais comuns, empregados para fracionar as principais globulinas, são os de WOLF et al., 1962; KOSHIYAMA, 1965 e THANH et al., 1975. Esses procedimentos são baseados nas diferentes solubilidades das globulinas em certas condições. Desses três métodos, o de THANH et al., 1975 é o mais utilizado porque é o mais rápido e permite um isolamento simultâneo das principais proteínas presentes na soja (fração do soro, 11S e $\beta$ e $\gamma$ conglicinina) (GARCIA et al., 1997). 


\subsection{Alergias Alimentares}

Aproximadamente entre 5 e $10 \%$ das crianças sofrem de alergia a um ou mais alimentos (SAMPSON, 1998) e tanto mecanismos imunológicos, quanto não imunológicos contribuem para o aparecimento de reações adversas. Em termos gerais, há três tipos de mecanismos que podem provocar sintomas, depois da ingestão de alguns alimentos: reações imunológicas, como por exemplo as do tipo I (mediadas por lgE); reações bioquímicas, tais como deficiências enzimáticas; e reações adversas a contaminantes alimentares, tais como drogas, corantes, conservantes etc. (CARVALHO, 1998).

As reações alérgicas aos alimentos podem ser mediadas por lgE, ou, resultar de mecanismos imunológicos não dependentes de $\lg E$. A função do anticorpo IgE na alergia alimentar está bem estabelecida (SAMPSON, 1999) e os sintomas típicos envolvem a pele, trato respiratório e/ou gastrointestinal (BOCK, 1990). Por outro lado, a patogênese das reações não mediadas por lgE ainda não está totalmente esclarecida, porém, sugere-se que as células $T$, macrófagos e outras classes de anticorpos estejam provavelmente envolvidos (SICHERER, 1999).

Inúmeros fatores afetam o desenvolvimento da alergia alimentar. Um deles é a freqüência de exposição a um alimento em particular, que é influenciado pela dieta e cultura de um país. Isso pode ter um efeito significante sobre a prevalência de uma alergia alimentar específica em uma determinada região, como por exemplo a alergia ao bacalhau na Noruega, arroz e soja no Japão e amendoim nos Estados Unidos da América. A via de exposição é outro fator importante no desenvolvimento da alergia alimentar. A permeabilidade do trato gastrointestinal é considerada o grande fator no desenvolvimento da sensibilização aos alimentos 
entretanto, poucos estudos têm sido desenvolvidos para investigar esse fenômeno. O processamento também é outro fator que pode, substancialmente, alterar o conteúdo do alérgeno no alimento. Além disso, fatores intrínsecos estão presentes: alguns alimentos, aparentemente, são muito alergênicos, enquanto que outros raramente provocam alergias (LEHRER, et al., 1996).

Apesar dos alimentos conterem uma grande variedade de proteínas, poucos alérgenos protéicos são conhecidos. Nos vegetais como soja e amendoim, os alérgenos parecem ser proteínas de estoque, as quais estão em grande quantidade nesses alimentos (HERIAN et al., 1990; BURKS et al., 1991a,b; BURKS et al., 1992). Contudo, as proteínas que estão em pequenas quantidades podem ter alto potencial alergênico, como por exemplo, a proteína Gad c 1 do bacalhau, que é altamente alergênica, mas que não é uma proteína predominante nesse peixe (AAS \& ELSAYED, 1969). Por outro lado, proteínas que estão em grande quantidade nos alimentos como actina e miosina, presentes na carne de gado, porco e galinha, não são alergênicas. Então, fica claro que, enquanto a dose de exposição é um fator crítico, a imunogenicidade, inerente de cada proteína, é muito mais importante (LEHRER, et al., 1996).

Os fatores que determinam a alergenicidade das proteínas ainda não estão totalmente esclarecidos. De uma maneira geral, os alérgenos alimentares são glicoproteínas com ponto isoelétrico ácido e massa molecular entre 10 e $40 \mathrm{KDa}$. Todavia, muitas proteínas não alergênicas possuem essas características. Por outro lado, proteínas com massa molecular acima de $70 \mathrm{KDa}$ podem ser alergênicas, como por exemplo o principal alérgeno do amendoim, Ara h 1, que é uma proteína de massa molecular entre 150 e 200 KDa (KING et al., 1995). 
Apesar de existirem exceções, muitos alérgenos alimentares potentes são moléculas estáveis que resistem ao processamento, cozimento e às enzimas digestivas. Por exemplo, a caseina e $\beta$ lactoglobulina, estáveis ao calor, são os principais alérgenos do leite de vaca, enquanto que a $\alpha$ lactoalbumina tem menor estabilidade térmica (RING et al., 2001).

Embora alguns alérgenos tenham sido estabelecidos, as características bioquímicas, funcionais e estruturais comuns nessas moléculas, que poderiam explicar a indução de anticorpos $\lg E$, ainda não estão esclarecidas. Recentemente, estudou-se uma possivel homologia dos aminoácidos, adjacentes ao resíduo catalítico da cisteína (Cys34), existente em uma proteína no ácaro da poeira (Der $p$ 1), com outros alérgenos, visto que a atividade proteásica desta está associada com a produção de lgE. Demonstrou-se que os alérgenos de diferentes origens têm similaridades estruturais, apresentando um tipo de fenda localizada entre as cadeias $\alpha$ e $\beta$, que poderia servir como local de ligação específica para a IgE (FURMONAVICIENE \& SHAKIB, 2001). Outra observação importante é que os grandes alérgenos devem ser polivalentes, isto é, devem ter vários epítopos que se ligam às moléculas de lgE, fixadas na superfície dos mastócitos, para ocorrer a desgranulação dessas células (LEHRER, 1996; FURMONAVICIENE \& SHAKIB, 2001).

Como comentado anteriormente, a alergia alimentar afeta de 1,5 a $2,5 \%$ dos adultos (YOUNG, 1994) e de 5 a 10\% das crianças (FURMONAVICIENE \& SHAKIB, 2001) envolvendo, em muitos casos de alergia em adultos, mecanismos mediados por IgE, enquanto que em crianças, há evidências de que varias delas 
sofram de alergia alimentar devido a eventos não dependentes de lgE (doença celíaca, gastroenterite eosinofilica, proctocolite e enterocolite) (METCALFE \& SAMPSON, 1990, SICHERER, 1999).

É citado na literatura que os principais alérgenos alimentares são o leite de vaca, ovo de galinha, peixe, frutos do mar, nozes, amendoin, frutas, soja, vegetais e trigo, os quais representam mais de $90 \%$ das alergias alimentares descritas mundialmente (SAMPSON \& ALBERGO, 1984; METCALFE et al., 1998).

Com relação à soja, sabe-se que ela tem sido utilizada por muitos séculos para a nutrição infantil por chineses e japoneses. Nos países ocidentais, as fórmulas contendo proteína de soja foram usadas, inicialmente, para alimentar crianças com alergia ao leite de vaca (HILL \& STUART, 1929), cuja freqüência está entre 0,3 a $7,5 \%$. Entretanto, as proteínas da soja são também utilizadas em casos de intolerância à lactose e galactose e na gastroenterite infantil grave (BUSINCO et al., 1992).

O quadro clínico na alergia à soja inclui vômitos, fezes aquosas com presença de muco, sangue e leucócitos, predominando os eosinófilos, além de aumento de glóbulos brancos acima de $4.000 / \mathrm{mm}^{3}$ e abcessos nos folículos intestinais, evidenciados por biópsia retal (POWELL, 1978).

A prevalência da alergia à soja ainda não foi especificamente estudada, porém vários pesquisadores têm obtido dados interessantes, tais como o estudo de alergia alimentar e intolerância, realizado por BOCK, 1987, em um grupo de 480 neonatos, dos quais dois $(0,4 \%)$ desenvolveram alergia à soja na infância. Em um outro estudo em crianças com dermatite atópica, avaliadas para hipersensibilidade alimentar, $5 / 113(4,4 \%)$ e $3 / 165(1,8 \%)$ reagiram à soja 
(SAMPSON \& MCCASKILL, 1985). Da mesma forma, em um estudo na Itália, as reações à soja apareceram em $6 / 505$ (1,2\%) das crianças com uma história sugestiva de alergia alimentar e em 1/243 $(0,4 \%)$ das crianças em risco de atopia, alimentadas com fórmulas à base de soja para profilaxia da alergia (BRUNO et al., 1997). Por outro lado, em um estudo realizado com o teste de provocação oral, em crianças com alergia ao leite de vaca, mediada por IgE, 13/93 (14\%) reagiram à soja (ZEIGER et al., 1999).

Enquanto esses estudos são especificamente direcionados às reações ao leite de vaca e soja, mediadas por $\operatorname{lgE}$, não se tem estudado as reações gastrointestinais à soja, mediadas por outros mecanismos imunológicos sem envolvimento da $\operatorname{lgE}$, como por exemplo a síndrome de enterocolite induzida por proteína alimentar, que é caracterizada por vômitos e diarréia tardia e com a elevação de leucócitos no sangue após a ingestão da proteína causal (BURKS, et al., 1994; SICHERER, et al., 1998). Entretanto, alguns pacientes têm desidratação severa, retardo de desenvolvimento e choque (MURRAY \& CHRISTIE, 1993; SICHERER, 2000), enquanto que outros, desenvolvem uma forma menos severa dessa enteropatia. Em crianças com essas reações à proteína do leite de vaca, 50\% também reagem à soja (BURKS, et al., 1994; SICHERER, et al., 1998).

Alguns modelos animais têm sido usados para avaliar a antigenicidade e alergenicidade das proteínas alimentares, principalmente as proteínas do leite de vaca, soja e ovos. Com base na titulação de anticorpos, no teste de Anafilaxia Cutânea Passiva (ACP), PAHUD et al., 1988, observaram que as proteínas da fração do soro e do extrato bruto de soja causaram menos sensibilização do que as proteínas do ovo e do leite de vaca. PIACENTINI et al.,1991, demonstraram 
que animais sensibilizados com proteína de soja não desenvolveram reação anafilática fatal, enquanto que essa reação foi desencadeada em animais sensibilizados com as proteínas do leite de vaca.

As fórmulas à base de soja são utilizadas para alimentar recém nascidos com alergia ao leite de vaca e pacientes geneticamente atópicos, quando o leite materno não está disponível, com o propósito de prevenir o aparecimento de doença atópica (BRUNO et al., 1993; BARDARE et al., 1993; BUSINCO et al., 1993). Sabe-se que as proteínas de soja são imunogênicas, mas com base em estudos experimentais e clínicos observou-se que são menos imunogênicas e alergênicas que as proteínas do leite de vaca (MAY et al., 1980; SAMPSON, 1988; PIACENTINI et al., 1991; GIAMPIETRO et al., 1992)

Mais recentemente, outras fórmulas especiais, provenientes da hidrólise das proteínas do leite de vaca, estão disponíveis no mercado, como alternativa alimentar às crianças alérgicas ao leite de vaca. Todavia, há evidências na literatura, de que as fórmulas parcialmente hidrolisadas e mais raramente, as altamente hidrolisadas, podem desencadear reações anafiláticas, que aumentam - risco de óbito das crianças com alergia ao leite de vaca, mediada por lgE (BUSINCO \& CANTANI, 1990; CANTANI \& BUSINCO, 1991; BUSINCO, 1994).

Vários estudos têm sido desenvolvidos para determinar qual é a fração protéica da soja mais alergênica, porém os resultados obtidos são contraditórios e não conseguiram, ainda, esclarecer essa questão. Sabe-se, entretanto, que a alergia à soja está associada às suas proteínas de estoque, constituídas principalmente pelas frações protéicas $2 S$, $7 S$ e $11 S$ da soja (BESLER et al., 2000). 


\subsection{Mecanismo imunológico das reações alérgicas}

Considerando as reações imunológicas do tipo lgE aos alimentos, sabe-se que há o envolvimento de várias células e citocinas que são fundamentais para direcionar a resposta imune à produção de anticorpos lgE.

Entre as várias células que participam diretamente da resposta imune, a célula $\mathrm{T}$ helper $\left(\mathrm{CD} 4^{+}\right)$é considerada a coordenadora fundamental dos eventos celular e humoral. Dependendo do estímulo antigênico, essas células são diferenciadas em dois subtipos de células efetoras, com funções distintas e mutualmente antagônicas, denominadas de Th1 e Th2 (CORRY \& KHERADMAND, 1999).

As células Th1 secretam interleucina 2 (IL-2), interferon $\gamma$ (IFN- $\gamma$ ), fator de necrose tumoral $\alpha(T N F-\alpha)$, linfotoxina e outras citocinas que, juntos, mobilizam os mecanismos de defesa celular e humoral contra patógenos. Além disso, a IL-2 e o IFN- $\gamma$ suprimem a síntese de anticorpos IgE, atuando indiretamente sobre as células Th2 (COFFMAN \& CARTY, 1986; PENE et al., 1988; LACK et al., 1994; NAKANISHI et al., 1995).

As células Th2 estimulam as células B a produzirem anticorpos com um desvio do isotipo IgM para IgE, bem como para IgG2 e $\lg G 4$ de humanos ou $\lg G 1$ e IgG3 de camundongos. Os antígenos que seletivamente estimulam essas células, as quais direcionam uma resposta lgE, são conhecidos como alérgenos. (ABBAS, 2000). As células Th2 secretam várias interleucinas, incluindo IL-4, IL-5, IL-6, IL-9 e IL-13. Acredita-se que essas citocinas coordenem a defesa do hospedeiro contra grandes patógenos extracelulares, assim como os helmintos 
(LOCKSLEY, 1994), além de estarem associadas à síntese de anticorpos lgE (PARRONCHI et al., 1991; ROBINSON, 1992).

O reconhecimento de antígenos pelas células $T$ é restrito ao complexo de histocompatibilidade principal $(\mathrm{MHC})$, porém nem todas as células $\mathrm{T}$ reconhecem o mesmo antígeno. Em geral, as células $\mathrm{T}$ helper expressam o marcador de superfície CD4 e reconhecem antígenos em associação com moléculas do MHC da classe II, enquanto que a maioria das células T citotóxicas expressam CD8 na sua superfície e reconhecem antígenos em associação com moléculas da classe I. Assim sendo, as células T citotóxicas, que são necessárias para destruir alvos infectados por vírus em qualquer tecido, reconhecem principalmente antígenos de moléculas da classe I, que são expressas em todas as células nucleadas. Por outro lado, as células $\mathrm{T}$ helper, que regulam e amplificam a resposta imune, reconhecem, principalmente, antígenos associados às moléculas da classe II, que estão presentes nas células apresentadoras de antígenos e células B (ROMAGNANI, 1994, 1998; ABBAS et al., 1996).

Vários estudos recentes têm enfatizado a importância da IL-4 e IL-13 na ativação do mecanismo intracelular envolvido no controle da resposta IgE. Após a ligação dessas citocinas (IL-4 e IL-13) com a cadeia $\alpha$ do receptor de IL-4 (IL4R $\alpha$ ), inicia-se uma cascata de sinalização que resulta na translocação do Stat 6 (transdutor de sinal e ativador da transcrição) para o núcleo da célula, culminando na produção de uma fita de RNA mensageiro do tipo epsilon (precursor do RNA mensageiro para $\operatorname{lgE}$ ) e a transcrição e início da produção da classe epsilon. Posteriormente, ocorre a recombinação onde o DNA codifica o domínio do 
anticorpo que é específico ao antígeno, além da região não ligante que é específica aos anticorpos IgE (HOU et al., 1994).

Além do IL4R $\alpha$, outros receptores e reguladores da transcrição também modulam a resposta IgE. Após o reconhecimento do antígeno, o receptor CD40 é expresso na superfície da célula B, o qual possui afinidade com seu ligante CD154 (CD40L), presente na superfície da célula T. Essa interação estimula principalmente o início da produção da classe $\operatorname{lgE}$ e o crescimento da célula $B$ (KAWABE et al., 1994). Somente a reação cruzada do CD40 com seu ligante é suficiente para estimular uma resposta IgE policlonal, mas quando combinada com os sinais provenientes do receptor de antígeno da célula $B$ (CD23), a resposta se torna específica ao antígeno (FERLIN, et al., 1996).

O provável fator iniciador da transcrição da cadeia epsilon, dependente de CD40, é o fator de transcrição NF-kappa $B(N F-k B)$, que interage de forma sinergística com o Stat-6 para se obter uma produção máxima de IgE (ICIEK et al., 1997; LINEHAN et al., 1998; WARREN et al., 1999).

Além dessas moléculas, outras também são expressas sobre a superfície da célula B, após a ligação com o alérgeno. As moléculas CD80 e CD86 (denominadas de B7-1 e B7-2) são ligantes co-estimulatórias que interagem com o receptor CD28 presente nas células $T$, produzindo um sinal de ativação adicional que é crucial à sobrevivência da célula $T$ e à secreção de citocinas. Embora muitas citocinas estimulem a produção de $\operatorname{lgE}, \quad$ INF- $\gamma$ é provavelmente o regulador negativo mais importante (SCHWARTZ, 1992). 
Entre os vários receptores associados ao anticorpo IgE, os receptores CD23 e o de alta afinidade para IgE (FcєRI) são os mais importantes. O Fc\&RI, presente na superfície de mastócitos, basófilos e eosinófilos ativados, se liga ao anticorpo IgE em baixas concentrações $\left(K_{a}=10^{9} \mathrm{M}^{-1}\right)$ prolongando, dessa forma, a meia vida da $\lg E$ in vivo. A ligação do anticorpo lgE com esse receptor, estimula a sua expressão, aumentando os efeitos biológicos da $\operatorname{lgE}$ quando o antígeno está presente (TADA et al., 1975). O receptor CD23 está presente em células B, células $\mathrm{T}$ ativadas, monócitos, eosinófilos, plaquetas, células dendríticas foliculares e algumas células epiteliais do timo. Pelo fato desse receptor ter de 100 a 1000 vezes menos afinidade para $\operatorname{lgE}$ do que o FCERI, ele foi denominado de receptor de baixa afinidade para $\operatorname{lgE}(\mathrm{FCERII})\left(\mathrm{K}_{\mathrm{a}}=10^{6}-10^{7} \mathrm{M}^{-1}\right)$. Embora controverso, o receptor CD23 parece ser um regulador negativo da síntese de lgE, porém pode aumentar a produção desse anticorpo em algumas condições. Há dois mecanismos propostos sobre a regulação do anticorpo lgE pelo receptor CD23: a) em uma fase intermediária da resposta imune alérgica, quando os níveis de IgE são suficientemente altos para se ligar ao receptor CD23, esses anticorpos podem ser capturados pelas células $B ;$ b) na fase seguinte, quando o alérgeno interage com as moléculas $\lg E$, fixadas nas células $B$, essas células apresentarão o antígeno às células $T$, que em resposta a esse estímulo, produzirão IL-4 e IL-13, sendo essas citocinas importantes em vários processos, assim como na expressão do próprio receptor CD23. Sabe-se, entretanto, que em situações onde ocorre excesso de $\operatorname{lgE}$ e antígeno, interagindo demasiadamente com o receptor 
CD23, ocorre um sinal inibitório que antagoniza os efeitos positivos da apresentação do antígeno (YOKOTA et al., 1988; CORY \& KHERADMAND, 1999).

É fato conhecido que os mastócitos desencadeiam uma indesejável reação alérgica em resposta a antígenos inócuos, os quais não estão associados com patógenos invasivos que necessitam ser eliminados do organismo. Essas células são provenientes de uma linhagem mielóide, diferente da associada aos basófilos e eosinófilos. Os mastócitos estão localizados em tecidos, na proximidade dos vasos sangüíneos e vênulas pós-capilares e possuem vários grânulos os quais contêm mediadores pré-formados e, recentemente, sintetizados no momento da ativação, provenientes tanto da via da lipoxigenase quanto da via da ciclooxigenase.

Os eosinófilos são leucócitos granulocíticos derivados da medula óssea. Essa denominação se dá porque seus grânulos, que contêm proteínas básicas ricas em arginina, são corados de cor laranja pelo corante acídico eosina. As funções efetoras dos eosinófilos são de dois tipos: a) liberação de proteínas altamente tóxicas e radicais livres dos grânulos que podem matar microorganismos e parasitas, mas que podem, também, causar dano tecidual significante em pessoas alérgicas; b) produção de prostaglandinas, leucotrienos e citocinas que amplificam a resposta inflamatória pelo recrutamento e ativação de eosinófilos, leucócitos e células epiteliais. Nesse contexto, um dado interessante é que, após a chegada dos eosinófilos ao sítio de contato com o antígeno essas células secretam IL-4 em quantidades suficientes para direcionar a resposta das células Th2, estabelecendo, dessa forma, um elo importante entre a imunidade inata (lisozima, complemento, proteínas de fase aguda, células exterminadoras 
naturais e fagócitos) e a resposta IgE (SABIN, et al., 1996). Sendo assim, os eosinófilos ativados têm um papel muito importante em vários processos patológicos nas doenças alérgicas e no combate aos parasitas

A ativação inapropriada e a degranulação de eosinófilos, que seria muito prejudicial ao organismo, é controlada por mecanismos regulatórios importantes. O primeiro mecanismo regula a produção de eosinófilos na medula óssea, onde permanece baixa na ausência de infecção ou de outra estimulação imune. Quando as células Th2 são ativadas, a IL-5 que é liberada estimula a produção de eosinófilos na medula óssea e promove sua liberação na circulação, mas não nos tecidos, demonstrando que há um segundo mecanismo, que regula a migração de eosinófilos da circulação aos tecidos. Sugere-se que essa resposta seja mediada pela eotaxina, que induz a quimiotaxia de eosinófilos. O terceiro mecanismo de regulação é controlado por seu estado de ativação. No estado basal, os eosinófilos não expressam FcєRI e têm um limiar alto para a liberação de seus grânulos. Após a ativação por citocinas e quimoquinas, esse limiar diminui, o FCERI é expresso e vários complementos de superfície e receptores Fcy aumentam. Em uma reação alérgica local, a ativação de células Th2 e degranulação de mastócitos causam acúmulo de eosinófilos ativados na região. A permanência dessas células no local é característica da inflamação alérgica crônica e da lesão tecidual (JANEWAY et al., 1999).

Os basófilos expressam receptores FceRI de superfície e sob ativação, liberam mediadores tóxicos de seus grânulos basofílicos. Essas células estão, normalmente, presentes em baixo número na circulação sangüínea e parecem 
desempenhar uma função similar a dos eosinófilos, na defesa contra os parasitas (JANEWAY, 1999).

Com relação ao desenvolvimento de uma reação alérgica, sabe-se que ela inicia quando o mesmo alérgeno de uma primeira exposição interage, cruzadamente, com duas moléculas de lgE, fixadas ao receptor Fc\&RI, presente na superfície dos mastócitos e basóf!los, desencadeando, conseqüentemente, uma cascata de sinalização nessas células, envolvendo várias proteína quinases, com posterior liberação de substâncias farmacologicamente ativas.

A resposta inflamatória, seguida da ativação dos mastócitos pela lgE, ocorre como uma reação imediata, iniciando dentro de segundos, que é proveniente da atividade das substâncias liberadas dos mastócitos/basófilos tais como a histamina, prostaglandinas e outros mediadores pré-formados ou rapidamente sintetizados, os quais causam um aumento instantâneo na permeabilidade vascular e contração da musculatura lisa. Por outro lado, a reação tardia demora de 4 a 8 horas para se desenvolver e é causada pela indução da síntese e liberação de mediadores como leucotrienos, quimoquinas e citocinas. Embora a reação tardia seja menos dramática do que a resposta imediata, ela está associada com uma segunda fase de contração da musculatura lisa e edema. Essa reação induz o recrutamento de leucócitos inflamatórios, incluindo especialmente eosinófilos e células Th2, para o sítio alvo do alérgeno. Dessa forma, pode haver o desenvolvimento de uma resposta inflamatória crônica, se o alérgeno estiver constantemente presente, com conseqüente promoção de eosinofilia e produção de lgE, pelas células Th2 (SICHERER, 1999). 


\subsection{JUSTIFICATIVA E OBJETIVO}

Sabendo-se que a soja é uma fonte importante de proteínas vegetais e seu valor nutricional comparável às fórmulas do leite de vaca (BUSINCO \& CANTANI, 1991), os produtos à base de soja são recomendados como uma alternativa alimentar às crianças alérgicas ao leite de vaca. Por outro lado, há registros na literatura de que a concomitante intolerância à soja, na alergia ao leite de vaca, está entre $0 \%$ e $63 \%$, entretanto, não há uma definição clara com relação à identificação da(s) fração(ões) mais alergênica(s). Para esclarecer essa questão, é necessário padronizar uma metodologia de extração e purificação das principais frações protéicas da soja para, posteriormente, utilizálas como ferramentas na padronização de ensaios biológicos que caracterizem a imunogenicidade e alergenicidade dessas proteínas, bem como, detectar a presença destas frações nos produtos derivados da soja e, possivelmente, fomecer às indústrias de alimentos uma alternativa de obtenção de produtos derivados da soja, isentos da fração alergênica.

Portanto, para se alcançar os objetivos gerais deste trabalho, pretendese:

- Avaliar a imunogenicidade e o potencial alergênico das frações protéicas 2S, 7S e 11S da soja, em camundongos;

- Verificar a presença de anticorpos lgE e lgG, dirigidos contra às frações 2S, $7 S$ e 11S da soja, em pacientes alérgicos; 
- Produzir anticorpos monoclonais dirigidos contra as frações protéicas 7S e 11S da soja;

- Padronizar um teste imunoenzimático para detectar proteínas da soja em produtos industrializados, utilizando-se os anticorpos monoclonais obtidos neste estudo. 


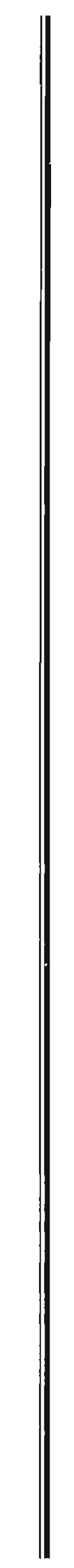

4.0 Material e Métodos 


\subsection{MATERIAL E MÉTODOS}

\subsection{Isolamento das frações protéicas $2 S, 7 S$ e $11 S$ da soja}

A fração 75 foi purificada a partir do isolado protéico da soja e as frações $2 S$ e $11 S$, a partir da farinha desengordurada da soja. Padronizou-se uma metodologia eficiente para a obtenção da fração 75 purificada, a partir da modificação da técnica de BURKS, et al., 1988 (Figura 3). As frações 2 S e 11 S foram obtidas pela modificação da técnica de THANH e SHIBASAKI, 1976a (Figura 4).

\subsection{Animais}

Utilizou-se camundongos albinos BALB/c machos e ratos Wistar machos, todos com aproximadamente 3 meses de idade, pesando entre 30 e 40 gramas e 150 e 200 g, respectivamente, provenientes do biotério do Instituto de Ciências Biomédicas, da Universidade de São Paulo (ICB-USP).

Os animais foram mantidos no biotério da Bioquímica Clínica do Departamento de Análises Clínicas e Toxicológicas da USP, sem restrição de água e alimento, constituído de ração comercializada Purina (Labina) específica para a alimentação de ratos e camundongos.

\subsection{Imunização dos animais}

\section{-Avaliação da produção de anticorpos IgM e IgG}

Grupos de 10 camundongos foram imunizados com as frações protéicas 2S, $7 S$ e 11S da soja, separadamente, em duas etapas. Inicialmente, esses animais receberam $50 \mu \mathrm{g}$ de antígeno emulsificado em adjuvante completo de Freund 
(1/2), administrando-se $200 \mu \mathrm{l} /$ animal via i.p. (intraperitoneal). Decorrido o período de 15 dias, esses animais receberam $100 \mu \mathrm{g}$ do mesmo antígeno, emulsificado em adjuvante incompleto de Freund (1/2), injetando-se a mesma quantidade de antígeno/animal via i.p.. Periodicamente, realizou-se sangrias pelo plexo oftálmico, visando a obtenção do soro (pool), utilizado para a avaliação da produção de anticorpos dirigidos contra as frações protéicas $2 S, 7 S$ e $11 S$ da soja.

\section{- Avaliação da produção de anticorpos IgE}

Grupos de sete camundongos BALB/c foram imunizados com $50 \mu \mathrm{g}$ (i.p.) das frações protéicas $2 S, 7 S$ e $11 S$ da soja, separadamente, acrescido com $7,5 \mathrm{mg}$ de hidróxido de alumínio, contidos em $0,5 \mathrm{~mL}$ de solução. Vinte e oito dias após a imunização, os animais receberam um reforço de $5 \mu \mathrm{g}$ do antígeno em 0,5 mL de salina, também por via i.p.. Os animais foram sangrados semanalmente $\left(7^{\circ}, 14^{\circ}\right.$, $21^{\circ}, 28^{\circ}$ e $35^{\circ}$ dias após a imunização) pelo plexo orbital e o soro de cada animal foi separado por centrifugação ( $800 \mathrm{~g}$, por $10 \mathrm{~min}$ ), e mantido à $-20^{\circ} \mathrm{C}$ até o dia da realização do teste.

Para a avaliação do potencial alergênico de cada uma das frações protéicas da soja, três ratos Wistar foram submetidos ao teste de Anafilaxia Cutânea Passiva (ACP) (item 4.6). 
- Produção de anticorpos monoclonais

Três camundongos BALB/c foram imunizados com as frações protéicas $7 S$ e $11 \mathrm{~S}$ da soja, separadamente (10 $\mu \mathrm{g}$ de proteína/pata), emulsificadas em adjuvante completo de Freund (1:2) e veiculado através do coxim plantar.

Em intervalos de 15 dias, os animais receberam reforços com a mesma concentração de antígeno (7S e 11S), emulsificado em adjuvante incompleto de Freund (1:2). Quatro dias antes da fusão, um animal do grupo recebeu um reforço de antígeno (10 $\mu \mathrm{g}$ de proteína/pata, diluído em salina estéril 1:2).

\subsection{Soros de pacientes}

$\mathrm{Na}$ avaliação da presença de anticorpos lgE e IgG, reativos às frações protéicas $2 \mathrm{~S}, 7 \mathrm{~S}$ e $11 \mathrm{~S}$, utilizou-se o soro de pacientes alérgicos à soja e controles (item 11.1), selecionados no Instituto da Criança do Hospital das Clínicas de São Paulo, cumprindo os requisitos da Res. 196/96 de 10 de outubro de 1996 e suas complementares. 


\subsubsection{Extração e purificação da fração 7S, a partir do isolado protéico da soja}

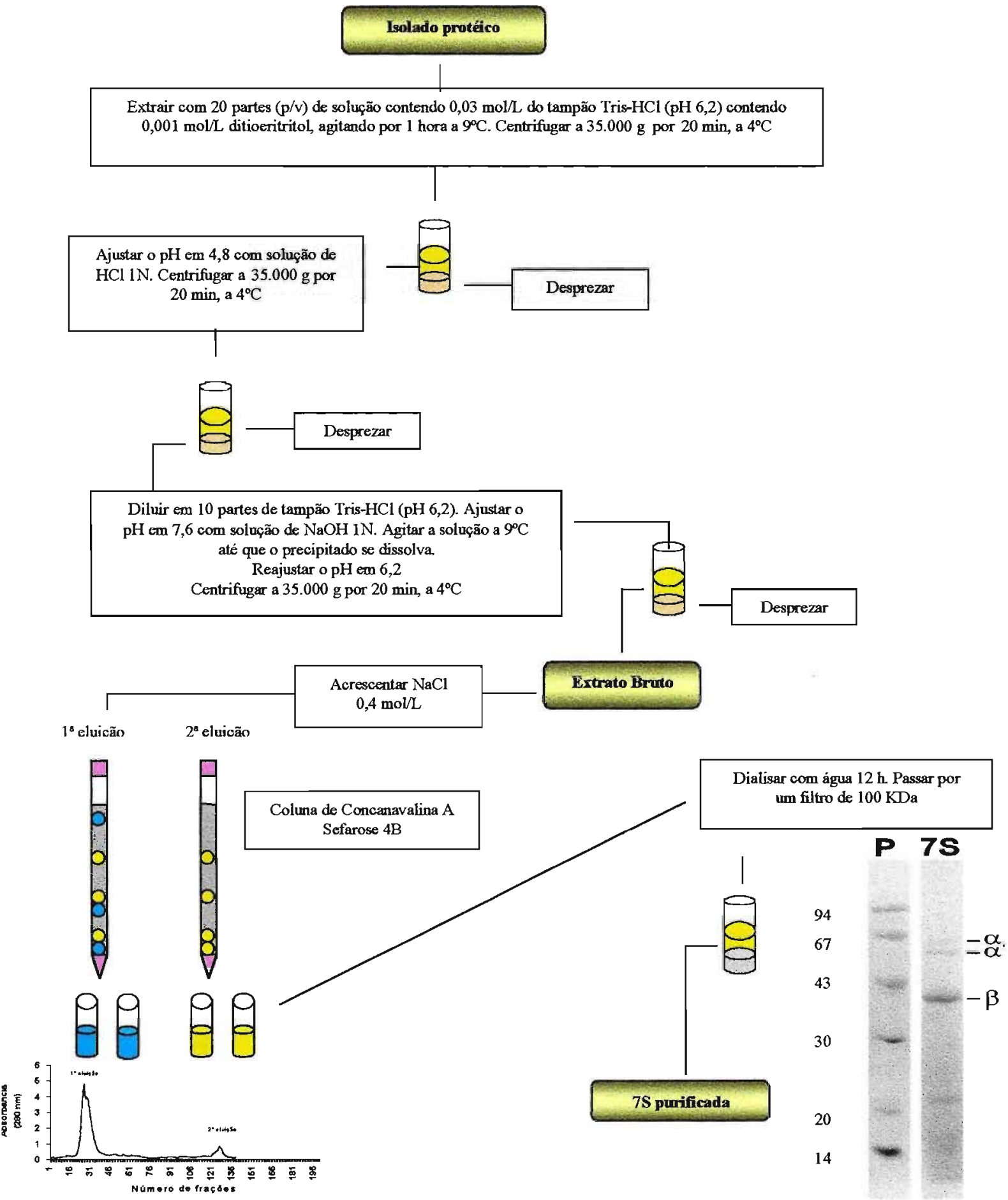

Figura 3 - Extração e purificação da fração protéica $7 S$ da soja com a respectiva caracterização por Eletroforese em gel de poliacrilanida. 
4.4.2 Extração e purificação das frações $2 S$ e 11S, a partir da farinha desengordurada de soja

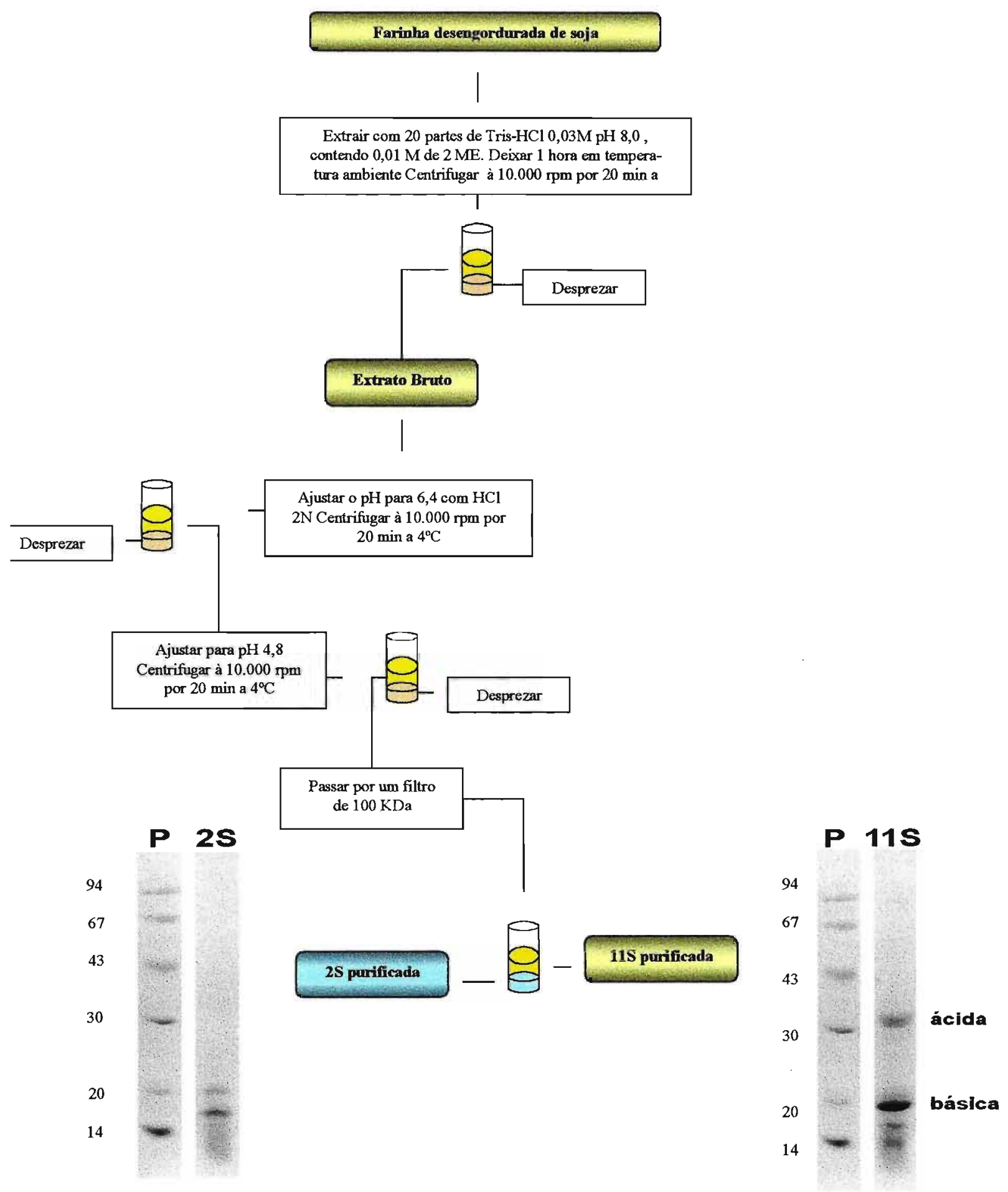

Figura 4 - Extração e purificação das frações protéicas $2 S$ e $11 \mathrm{~S}$ da soja com as respectivas caracterizações por Eletroforese em gel de poliacrilamida. 


\subsection{Avaliação da produção de anticorpos das classes IgM e IgG dirigidos contra as frações protéicas $25,7 S$ e 115 da soja, em camundongos}

Placas de poliestireno de 96 poços [ELISA (EIA/RAI, Costar, Cambridge, MA, USA)] foram acopladas com $50 \mu$ das frações protéicas $2 S, 7 S$ e 11 S da soja, separadamente $\left(1 \mu \mathrm{g} /\right.$ poço) e, posteriormente, incubadas por 12 horas a $37^{\circ} \mathrm{C}$. Após a sensibilização, as placas foram bloqueadas com leite desnatado a $5 \%$ em PBS (tampão fosfato salina), $\mathrm{pH} 7,2$ e incubadas por $2 \mathrm{~h}$ a $37^{\circ} \mathrm{C}$. Após o bloqueio, as placas foram lavadas com PBS + Tween $20(0,05 \% \mathrm{v} / \mathrm{v})$ e incubadas por $2 \mathrm{~h}$ a $37^{\circ} \mathrm{C}$ com $50 \mu \mathrm{l}$ do soro teste em cada cavidade. As etapas seguintes incluíram a lavagem das placas de ELISA como descrito acima, adição de $50 \mu$ de conjugado anti IgG ou IgM de camundongo marcado com fosfatase alcalina [Alkaline Phosphatase Conjugated Affinity Purified Anti-Mouse IgG (sheep), IgM (Heavy Chain Specific, Goat), Rockland] e diluído a 1:1000 em leite desnatado a 1\% em PBS, $\mathrm{pH} 7.2$, incubando-se em seguida, a $37^{\circ} \mathrm{C}$ por 2 horas. Após a lavagem das placas, adicionou-se a solução contendo substrato e cromógeno específicos para fosfatase alcalina (item 11.4b) deixando-se por 30 min à temperatura ambiente, sob a proteção da luz. A reação foi bloqueada com $50 \mu \mathrm{l}$ de $\mathrm{NaOH} 3 \mathrm{M}$ e a absorbância lida em 405 nm. A intensidade de coloração foi proporcional à concentração da enzima fosfatase presente no teste, que por sua vez, reflete a concentração de anticorpos aderidos à placa. 


\subsection{Teste de Anafilaxia Cutânea Passiva (ACP)}

Para a determinação dos títulos de anticorpos anafiláticos da classe lgE em soros de camundongos, utilizou-se a técnica de ACP descrita por MOTA \& WONG, 1969. Ratos depilados no dorso foram sensibilizados, intradermicamente, com $100 \mu$ de diluições seriadas de pools de soros obtidos de grupos de camundongos imunes às frações protéicas $2 S, 7 S$ e 11 da soja, separadamente. Para a composição das amostras, foram agrupados volumes iguais de soro de cada camundongo, de cada sangria realizada $(7,14,21,28$ e 35 dias depois da imunização). Após 18 e $24 \mathrm{~h}$, os ratos foram desafiados, intravenosamente, com $1 \mathrm{~mL}$ de $\mathrm{AE}$ (Azul de Evans) a $0,25 \%$ contendo $0,5 \mathrm{mg}$ do mesmo antígeno utilizado na imunização para a obtenção dos soros. A leitura da reação foi feita 2 h após o desafio, sacrificando-se os animais e observando-se o diâmetro da reação na pele invertida. O título de IgE foi expresso como a recíproca da maior diluição dos soros, que resultou em uma reação positiva com mais de $5 \mathrm{~mm}$ de diâmetro. Os testes foram realizados em triplicata e somente as diferenças superiores a 2 animais foram consideradas significativas.

\subsection{Análise da presença de anticorpos IgE e IgG, reativos às frações protéi-} cas 2S, 75 e 115 da soja, no soro de pacientes alérgicos

A padronização da técnica de ELISA para investigar a presença de anticorpos das classes lgE e lgG no soro de pacientes alérgicos, foi realizada utilizandose placas de poliestireno de 96 poços (EIA/RAI, Costar, Cambridge, MA, USA). A sensibilização foi feita com $50 \mu$ das frações protéicas $2 S, 7 S$ e $11 S$ da soja, se- 
paradamente, na concentração de $1 \mu \mathrm{g}$ de proteína/poço, sendo as placas incubadas por 1 hora a $37^{\circ} \mathrm{C}$. Após o período de sensibilização, as placas foram bloqueadas com leite desnatado a $5 \%$ em PBS, $\mathrm{pH} 7.2$, e incubadas por $2 \mathrm{~h}$ a $37^{\circ} \mathrm{C}$.

Após a lavagem das placas com PBS + Tween $20(0,05 \%$ v/v), a análise de anticorpos lgG consistiu na adição de $100 \mu \mathrm{l}$ dos soros dos pacientes alérgicos e controles, diluídos de 1/20 a 1/2580 com leite desnatado a 1\%, em PBS, pH 7,2, com posterior incubação das placas por $1 \mathrm{~h}$ a $37^{\circ} \mathrm{C}$. Passado o tempo de incubação, as placas foram lavadas como descrito acima e, em seguida, foi adicionado $100 \mu \mathrm{l}$ de conjugado anti IgG humana marcada com peroxidase (Peroxidase Conjugated Affinity Purified Ariti-human IgG (H\&L), Rockland), diluída a 1:1000 com leite desnatado a $1 \%$. As placas foram incubadas por $1 \mathrm{~h}$ a $37^{\circ} \mathrm{C}$, lavadas e adicionadas com $100 \mu \mathrm{l}$ da solução contendo substrato e cromógeno específicos para peroxidase (item 11.4b), incubando-se, em seguida, por 30 min à temperatura ambiente. A absorbância foi monitorada a $405 \mathrm{~nm}$.

Para a análise de anticorpos $\operatorname{lgE}$, os soros foram diluídos 1/21 e previamente absorvidos com RF-Absorbent (Dade Behring), incubando-se, em seguida por 1h a $37^{\circ} \mathrm{C}$. O RF-Absorbent por ser uma IgM direcionada contra os anticorpos da classe IgG, foi utilizado com o objetivo de retirar do soro os anticorpos IgG específicos contra as frações protéicas da soja e, conseqüentemente, de eliminar a probabilidade da ocorrência de competição entre anticorpos lgG e lgE pelos mesmos sítios protéicos da soja. A fase seguinte consistiu da lavagem das placas, adição de $100 \mu$ de anticorpos anti IgE biotinilados (Affinity Purified Antibody Biotin Labeled Goat anti human IgE, KPL), diluidos 1:1000 em leite desnatado a 1\% em PBS, 
pH 7,2 e incubação por $1 \mathrm{~h}$ a $37^{\circ} \mathrm{C}$. Posteriormente, as placas foram lavadas e incubadas com $100 \mu \mathrm{l}$ de avidina peroxidase (Peroxidase Conjugated Avidin, Rockland) (diluida $1: 5000$ em leite desnatado a $1 \%$ ) por $1 \mathrm{~h}$ a $37^{\circ} \mathrm{C}$. Após a lavagem das placas e adição de $100 \mu l$ da solução contendo substrato e cromógeno para peroxidase (item 11.4b), as placas foram incubadas por 30 min à temperatura ambiente e a absorbância monitorada a $405 \mathrm{~nm}$.

\subsection{Produção de Anticorpos monoclonais}

A produção de anticorpos monoclonais, dirigidos contra as frações protéicas $7 \mathrm{~S}$ e $11 \mathrm{~S}$ da soja, visou a padronização de uma metodologia para identificar as proteínas da soja em produtos comercializados.

As diversas etapas utilizadas na produção dos anticorpos monoclonais reativos às frações $7 \mathrm{~S}$ e $11 \mathrm{~S}$ estão representadas, resumidamente, na Figura 5. 


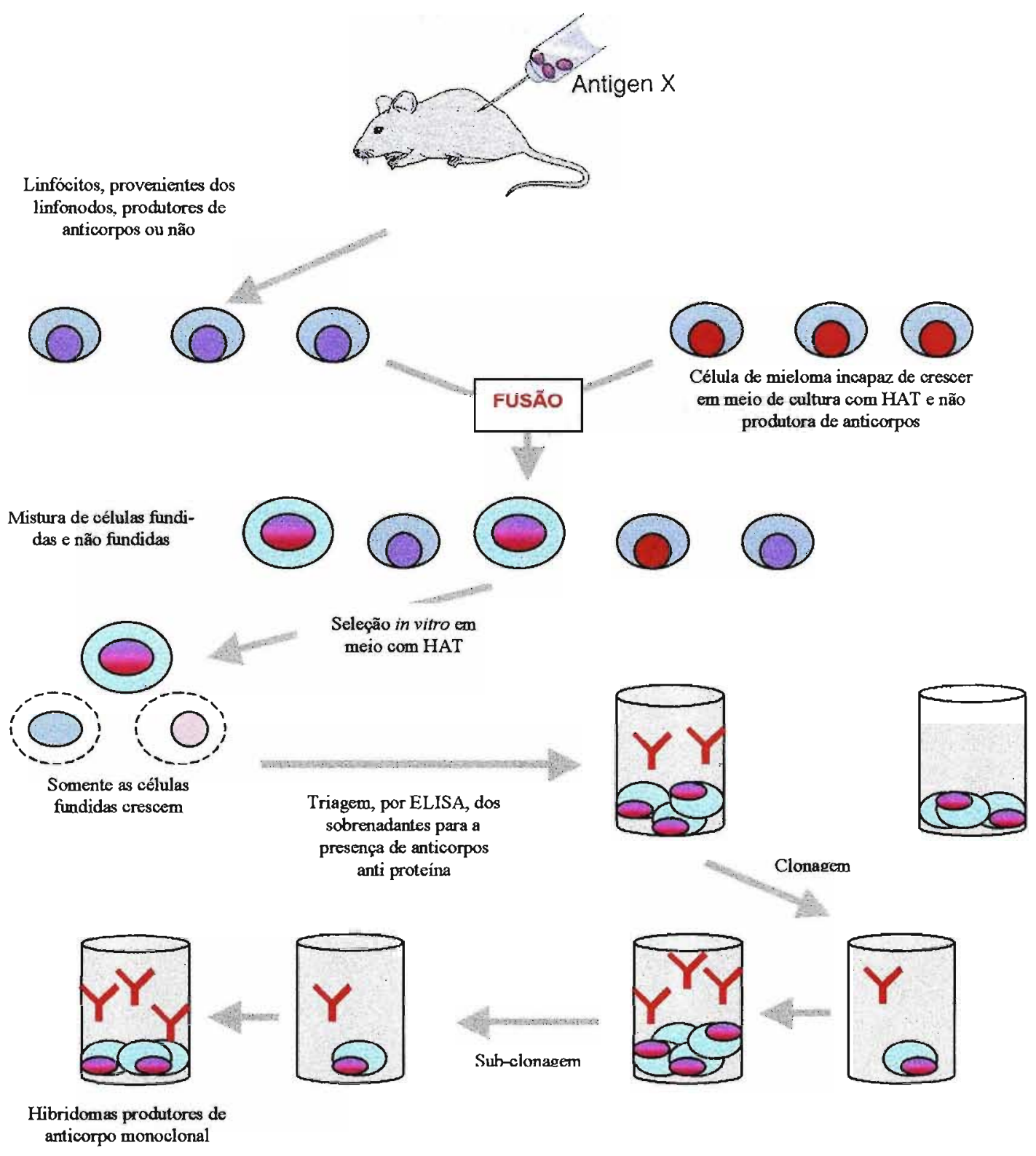

Figura 5 - Esquema simplificado da produção de anticorpos monoclonais

\subsubsection{Descongelamento e expansão de células de mieloma SP2-O}

As ampolas contendo células de mieloma não secretor SP2-O foram retiradas do tanque de nitrogênio líquido e, rapidamente, descongeladas em banhomaria a $37^{\circ} \mathrm{C}$. Após o descongelamento, as células foram transferidas para um 
tubo cônico contendo $20 \mathrm{~mL}$ de meio de cultura RPMl+ (item 11.4d). As células foram lavadas duas vezes, por centrifugação a $500 \mathrm{~g}$ por $5 \mathrm{~min}$, à temperatura ambiente e, em seguida, transferidas para frascos de cultura de células de $75 \mathrm{~cm}^{2}$ com meio de cultura RPMI+ e mantidas em estufa a $37^{\circ} \mathrm{C}$ com $5 \%$ de $\mathrm{CO}_{2}$.

\subsubsection{Preparo de monocamada de fibroblastos e macrófagos}

Para o preparo da monocamada de fibroblastos e macrófagos, obteve-se células do peritônio de camundongos $B A L B / c$, no dia anterior à fusão.

Para tanto, injetou-se $5 \mathrm{~mL}$ de RPMI+ (item 11.4d) na cavidade peritoneal do animal massageando-se o abdômen exposto. Em condições estéreis, o líquido peritoneal foi removido e diluído em aproximadamente $50 \mathrm{rIL}$ de RPMl+. Esta suspensão foi distribuída à razão de $0,2 \mathrm{~mL} /$ poço em placas de cultura de 96 poços (Culture Plate, Costar, Cambridge, MA, USA), que foram mantidas a $37^{\circ} \mathrm{C} \mathrm{em}$ atmosfera úmida contendo $5 \%$ de $\mathrm{CO}_{2}$.

\subsubsection{Protocolo de fusão celular}

Um camundongo BALB/c imunizado (ítem 4.2) e avaliado quanto à capacidade de produzir anticorpos policlonais dirigidos contra as frações protéicas 7 S ou $11 S$ da soja, foi sacrificado em recipiente fechado com éter etílico, sendo os linfonodos popliteais retirados sob condições estéreis. Os linfonodos foram macerados e lavados cuidadosamente com meio RPMI- (item 11.4d) e os linfócitos recuperados. Essa solução foi centrifugada por 5 min a $500 \mathrm{~g}$. A viabilidade dos linfócitos e das células de mieloma SP2-O (previamente cultivadas) foi determinada por coloração com azul de trypan e contagem em câmara de Neubauer. Nessa análise os 
dois grupos de células apresentaram viabilidade superior a 90\%. A concentração das células foi ajustada com meio de cultura para a proporção 1:2 (mieloma/linfócitos) e após, centrifugadas por 5 min a $500 \mathrm{~g}$. O sobrenadante foi descartado, sendo o sedimento ressuspenso, lentamente e gota a gota, com 1,0 mL de polietileno glicol 50\% (PEG) por 60 seg. Em seguida, as células foram incubadas por $90 \mathrm{seg}$ a $37^{\circ} \mathrm{C}$. Ao final dessa etapa, adicionou-se $1,0 \mathrm{~mL}$ de RPMI-, gota a gota, em 60 seg. Posteriormente, adicionou-se $20 \mathrm{~mL}$ de RPMI-, gota a gota, em 4 min e incubou-se as células por igual período a $37^{\circ} \mathrm{C}$. Passado esse tempo, as células foram centrifugadas por $5 \mathrm{~min}$ a $500 \mathrm{~g}$, sendo o sobrenadante descartado. Ao sedimento de células adicionou-se RPMI+ contendo HAT (histidina 200 mM, aminopterina $0,8 \mathrm{M}$ e timidina $32 \mathrm{mM}$ ) até a concentração final de $1,0 \times 10^{6}$ células $/ \mathrm{mL}$. As células fundidas foram mantidas em repouso por três horas a $37^{\circ} \mathrm{C} \mathrm{e}$, depois, distribuídas nas placas, previamente preparadas com a monocamada de fibroblastos e macrófagos (100 $\mu \mathrm{l} / \mathrm{poço})$ e incubadas em estufa a $37^{\circ} \mathrm{C} \mathrm{com} 5 \%$ de $\mathrm{CO}_{2}$. Decorridos três dias, o sobrenadante das células fundidas (híbridas) passou a ser trocado em intervalo de 2 dias, utilizando-se os diferentes meios de cultura: na primeira semana utilizou-se RPMI+ com HAT, nas 3 semanas seguintes RPMI+ com HT (histidina $200 \mathrm{mM}$ e timidina $32 \mathrm{mM}$ ) e posteriormente, manteve-se as células em meio RPMI+.

\subsubsection{Triagem dos clones}

Duas semanas após a fusão, os sobrenadantes de cultura dos clones que ocupavam $50 \%$, ou mais, da cavidade da placa de cultura, foram testados quanto à reatividade contra às frações protéicas $7 \mathrm{~S}$ e $11 \mathrm{~S}$ da soja, pelo teste de ELISA. 
As etapas de sensibilização e bloqueio das placas foram idênticas às descritas no item 4.5. Após o bloqueio e lavagem das placas com PBS + Tween $20(0,05 \%$ $\mathrm{v} / \mathrm{v})$, alíquotas do sobrenadante das culturas $(50 \mu \mathrm{l} / \mathrm{poço})$ foram incubadas a $37^{\circ} \mathrm{C}$ por 1 hora. Transcorrida a incubação, as placas foram lavadas e, em seguida, foi adicionado o conjugado anti-IgG de camundongo marcado com peroxidase (Peroxidase Conjugated Affinity Purified Anti-Mouse IgG (H\&L), Goat, Rockland) diluído 1:1000 em leite desnatado a 1\%, em PBS, $\mathrm{pH} 7,2$. As placas foram incubadas a $37^{\circ} \mathrm{C}$ por 2 horas e, posteriormente, lavadas, conforme descrito acima. A reatividade às proteínas da soja foi revelada utilizando-se $50 \mu \mathrm{l}$ da solução contendo substrato e cromógeno para peroxidase (11.4b). A reação de cor foi estabelecida após incubação das placas por 30 min à temperatura ambiente, sendo a absorbância determinada a $405 \mathrm{~nm}$. Todas as análises foram realizadas em duplicata.

Os hibridomas positivos (absorbância $>0,5$ ) foram selecionados pela capacidade de secretar anticorpos dirigidos contra as frações da soja, determinados pela técnica de ELISA, utilizando-se o sobrenadante de cultura.

\subsubsection{Diluição limitante}

A utilização do protocolo da diluição limitante teve por objetivo obter uma diluição final dos hibridomas selecionados como positivos (produtores de anticorpos contra as frações da soja), contendo, apenas, uma única célula por poço.

\subsubsection{Clonagem e sub-clonagem dos hibridomas}

Após o processo de diluição limitante, todos os poços das placas de cultura foram monitorados, diariamente, quanto ao crescimento celular, sendo excluídos 
aqueles que continham duas ou mais células iniciais. Quando o crescimento do clone atingiu aproximadamente $50 \%$ do poço, este foi novamente testado por ELISA (item 4.8.4) quanto a sua reatividade em relação às proteínas da soja. Aqueles, cuja resposta positiva se manteve específica e estável, foram expandidos, sendo parte congelada. Dessas células clonadas, um clone foi selecionado para ser sub-clonado. Nesta etapa, o mesmo procedimento de diluição limitante foi repetido, visando garantir a monoclonicidade da célula produtora de anticorpos contra as frações protéicas $7 \mathrm{~S}$ ou $11 \mathrm{~S}$ da soja.

\subsubsection{Isotipagem dos anticorpos monoclonais}

A análise dos isotipos dos anticorpos dos sobrenadantes de cultura dos hibridomas, foi realizada pelo teste de ELISA. Utilizou-se o Kit comercial para isotipagem (Mouse Monoclonal Antibody Isotyping Reagent, Sigma Chemical Co., St. Louis, USA), onde avaliou-se a reatividade às classes e aos isotipos de anticorpos de camundongos (IgA, IgM, IgG2a, IgG2b e IgG3).

\subsubsection{Produção de ascite em camundongos}

Os tumores ascíticos foram induzidos em camundongos BALB/c através da administração i.p. de 0,5 mL de adjuvante incompleto de Freund/animal. Depois de três semanas, os animais foram irradiados com raio gama (500 rads). As células produtoras de anticorpos, previamente lavadas com RPMI+, foram ressuspensas em salina estéril $(0,5 \mathrm{~mL} / \mathrm{animal})$ e injetadas na cavidade peritoneal dos camundongos, um dia após a irradiação. Aproximadamente após 10 dias da inoculação das células, o líquido ascítico foi recuperado, por punção intraperitoneal. O objeti- 
vo da produção de líquido ascítico foi o de expandir as células produtoras de anticorpos e, desse modo, obter uma concentração maior de anticorpos monoclonais dirigidos contra as proteínas da soja.

\subsubsection{Purificação dos anticorpos monoclonais}

- Deslipidação do líquido ascítico

Após a recuperação do líquido ascítico, este foi centrifugado, sendo o sobrenadante transferido para um outro tubo e as células descartadas. Ao sobrenadante, adicionou-se $20 \mu \mathrm{L}$ de sulfato de dextran a $10 \%$ e $0,1 \mathrm{~mL}$ da solução de cloreto de cálcio $1 \mathrm{M}$ por $\mathrm{mL}$ de líquido ascítico. Em seguida, a solução foi agitada mecanicamente por 15 min e, posteriormente, centrifugada a $5000 \mathrm{~g}$ por $10 \mathrm{~min}$. O sobrenadante recuperado, que correspondeu à amostra isenta de lipídeos, foi dialisado contra o tampão borato-salina por 24 horas, trocando-se 3 vezes a solução durante esse período.

\section{- Purificação}

Feita a deslipidação, o sobrenadante foi aplicado em uma coluna de Sepharose-Proteína A (Hitrap Protein-A, Pharmacia, Biotech)], utilizando-se 3 tampões, cuja finalidade foi a de separar alguns isotipos das imunoglobulinas. Assim sendo, utilizou-se o tampão borato-salina $\mathrm{pH} \mathrm{8,5}$ (item 11.4d) que tem a função de lavar a coluna e eliminar todas as proteínas não aderidas; tampão citrato pH 5,5 (item 11.4d) cuja função é a de eluir os anticorpos da classe IgG, subtipo IgG1 e, por último, o tampão glicina $\mathrm{pH} 2,8$ (ítem 11.4d) que elui os anticorpos da classe IgG, 
subtipos IgG1, IgG2a, IgG2b e IgG3, Coletou-se todos os 3 picos eluídos da coluna de proteína A para posterior avaliação do grau de eficiência da purificação.

\subsubsection{Análise da especificidade dos anticorpos monoclonais}

\section{- Processo de transferência das proteínas}

Depois da corrida eletroforética, o gel foi colocado em tampão de transferência (ítem 11.4c) por 30 min e transferido para a membrana de nitrocelulose utilizando-se o equipamento de transferência Nova Blot semi-dry (Pharmacia Biotech.), tendo sido a amperagem calculada pela área do gel $x$ 0,8. Deixou-se transferindo por 2 horas e após esse período a membrana foi corada, levemente, com o corante vermelho de Ponceau para se constatar a transferência das proteínas.

\section{- Avaliação dos determinantes antigênicos, reconhecidos pelos anticor- pos monoclonais}

Esta análise nos permitiu detectar a proteína, imobilizada na membrana de nitrocelulose, que é reconhecida pelo anticorpo monocional. Depois da transferência das frações proteícas $7 \mathrm{~S}$ e $11 \mathrm{~S}$ e do extrato bruto da soja, que contém todas as frações protéicas, a membrana de nitrocelulose com as proteínas fixadas e coradas com Ponceau, foram cortadas em tiras finas e incubadas, separadamente, com leite desnatado a 5\%, diluído com Tris salina (item 11.4c) por $2 \mathrm{~h}$ à temperatura ambiente, sob agitação. A etapa seguinte incluiu a lavagem das membranas com Tris salina e, posterior incubação com o sobrenadante de cultura, dos hibridomas produtores de anticorpo monoclonal, ou com o líquido ascítico diluído 1:100 com salina, contendo o anticorpo monoclonal $(1 \mathrm{H} 4=1,57 \mathrm{mg} / \mathrm{mL} ; 2 \mathrm{~A} 8=1,62$ 
$\mathrm{mg} / \mathrm{mL} ; 1 \mathrm{~F} 9=1,66 \mathrm{mg} / \mathrm{mL}$ e $3 \mathrm{~F} 2=2,04 \mathrm{mg} / \mathrm{mL})$, por $2 \mathrm{~h}$ à temperatura ambiente, sob agitação. Efetuada a lavagem das membranas, adicionou-se o conjugado anti-lgG de camundongo marcado com peroxidase [Peroxidase Conjugated Affinity Purified Anti-Mouse IgG (H\&L), Goat, Rockland], diluído 1:500 em leite desnatado a 1\% com Tris salina, incubando-se por 2 h à temperatura ambiente, sob agitação. A próxima etapa consistiu da lavagem das membranas e posterior adição da solução contendo substrato e cromógeno para peroxidase (item 11.4c). Esperou-se alguns minutos até o aparecimento da banda de cor preta, que caracterizou a proteína reconhecida pelo anticorpo monoclonal. A reação foi interrompida pela lavagem das membranas com água corrente.

\subsection{Deteç̧ão de proteínas da soja, em produtos comercializados}

Para padronizar a técnica de ELISA com o propósito de detectar as proteínas da soja em produtos comercializados (Tabela 2), utilizou-se placas de 96 poços (EIA/RAI, Costar, Cambridge, MA, USA). A sensibilização foi feita com $50 \mu$ I dos produtos comercializados "in natura" na concentração de $1 \mu \mathrm{g}$ proteína/poço em tampão carbonato-bicarbonato $\mathrm{pH} 9,6$ incubando-se em seguida por $12 \mathrm{~h}$ a $37^{\circ} \mathrm{C}$, em câmara úmida. Decorrido o período de sensibilização, as placas de ELISA foram bloqueadas com leite desnatado a 5\% em PBS, $\mathrm{pH} 7,2$, e incubadas por $2 \mathrm{~h}$ a $37^{\circ} \mathrm{C}$. A etapa posterior consistiu da lavagem das placas com PBS + Tween $20(0,05 \% v / v)$, adição de $100 \mu$ do sobrenadante de cultura dos hibridomas produtores de anticorpo monoclonal e incubação por $1 \mathrm{~h}$ a $37^{\circ} \mathrm{C}$. Após novo ciclo de lavagens, as placas foram incubadas por $1 \mathrm{~h}$ a $37^{\circ} \mathrm{C}$ com $100 \mu \mathrm{l}$ do conjugado anti IgG de camundongo marcado com peroxidase [Peroxidase Conjugated Affinity 
Purified Anti-Mouse IgG (H\&L), Goat, Rockland]. Após a incubação, as placas foram lavadas e, em seguida, adicionadas de $100 \mu \mathrm{l}$ da solução contendo substrato e cromógeno para peroxidase (item 11.4b), incubando-se por 30 min à temperatura ambiente. A absorbância foi monitorada a $450 \mathrm{~nm}$.

Tabela 2 - Produtos comercializados à base de soja.

$\begin{array}{cc}\begin{array}{c}\text { Concentração protéica total } \\ \text { (mg/ml) } \\ 11,6\end{array} & \text { Produto comercializado } \\ 7,98 & \text { Suco de frutas Ades } \\ 15,8 & \text { Suco de fruta Soy fruit } \\ 8,0 & \text { Mupi, alimento à base de soja } \\ 16,0 & \text { logurte Tonyu } \\ \text { 4.10 Análise estatística } & \\ \text { Utilizou-se o teste de ANOVA univariada para analisar os resultados do teste } \\ \text { imunoenzimático, que investigou a presença de anticorpos séricos das classes IgE } \\ \text { e IgG, dirigidos contra as frações protéicas } 2 S, 75 \text { e 11S da soja, em pacientes } \\ \text { alérgicos e controles. }\end{array}$




\section{RESULTADOS}

\subsection{Avaliação da cinética da produção de anticorpos lgM e lgG dirigidos} contra as frações protéicas 25,75 e 115 da soja

Para se investigar a imunogenicidade das frações protéicas $2 S, 7 S$ e $11 \mathrm{~S}$ da soja, em roedores, dez camundongos BALB/C foram imunizados, separadamente, com essas frações (ítem 4.2) e, periodicamente, sangrados pelo plexo orbital. O pool dos soros, obtido por centrifugação a $800 \mathrm{~g}$ por $10 \mathrm{~min}$, foi analisado por ELISA, investigando-se a presença de anticorpos das classes IgM e IgG dirigidos contra às referidas frações protéicas da soja.

Com relação à fração protéica $2 S$ da soja, não foi detectado a produção de anticorpos da classe IgM pelo método utilizado, em nenhum dos tempos pósimunização testados. Por outro lado, observou-se uma pequena produção de anticorpos IgG contra essa fração, principalmente, 30 dias após a imunização (Figura 6).

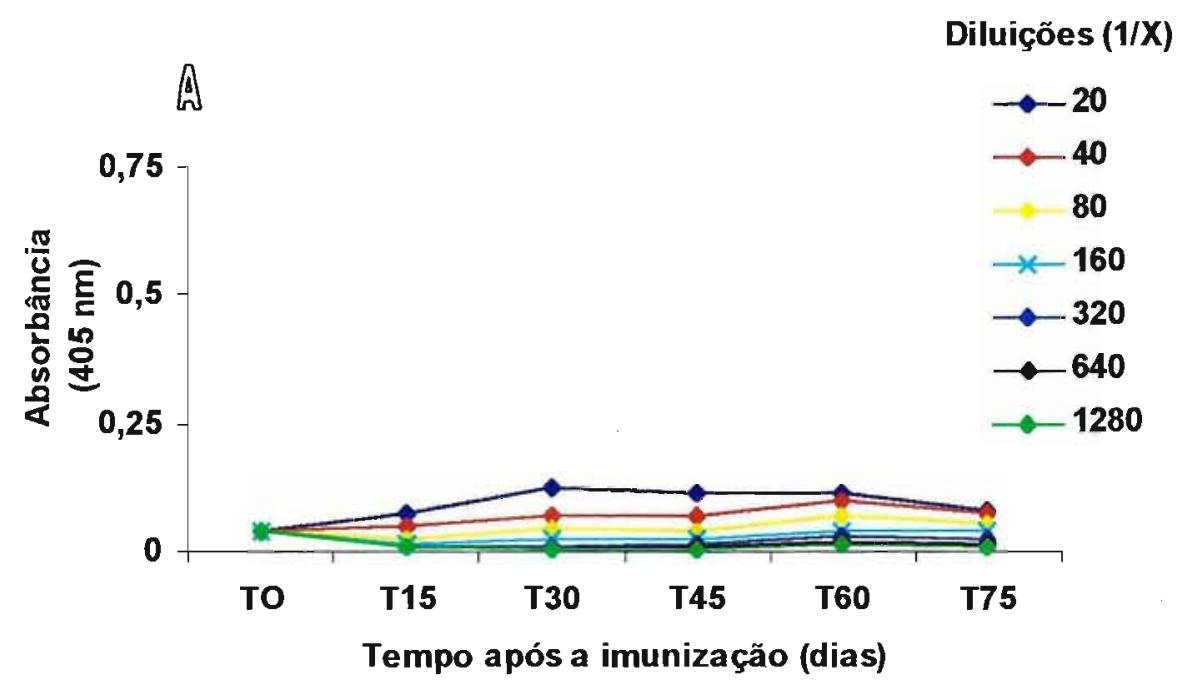




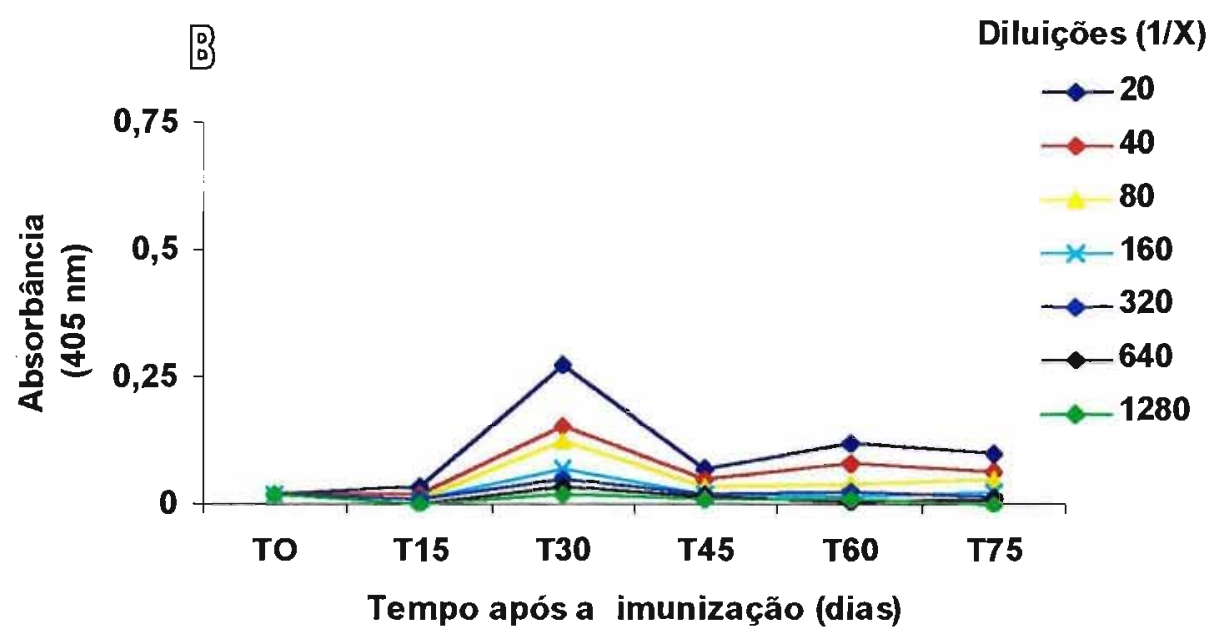

Figura 6 - Avaliação da cinética da produção de anticorpos das classes $\operatorname{lgM}(A)$ e IgG (B) direcionados à fração protéica $2 S$ da soja, após a imunização de camundongos $\mathrm{BALB} / \mathrm{C}$.

TO - Tempo de coleta do sangue anterior à imunização.

Os dados são expressos como a média das análises em duplicata.

Quando avaliamos a cinética da produção de anticorpos IgM contra à fração $7 S$ da soja, observou-se a presença de uma grande resposta humoral entre o $21^{\circ}$ e $87^{\circ}$ dia após a imunização dos camundongos. Evidenciou-se um pico no $54^{\circ}$ dia e a intensidade da reação, no teste de ELISA, foi indiretamente proporcional à diluição. A fração $7 S$ também induziu uma resposta imunogênica com a formação de anticorpos IgG do $21^{\circ}$ ao $114^{\circ}$ dia, após a imunização. O pico de produção de anticorpos ocorreu entre o $54^{\circ}$ e $87^{\circ}$ dia e as absorbâncias foram decrescentes de acordo com o aumento das diluições das amostras (Figura 7). 

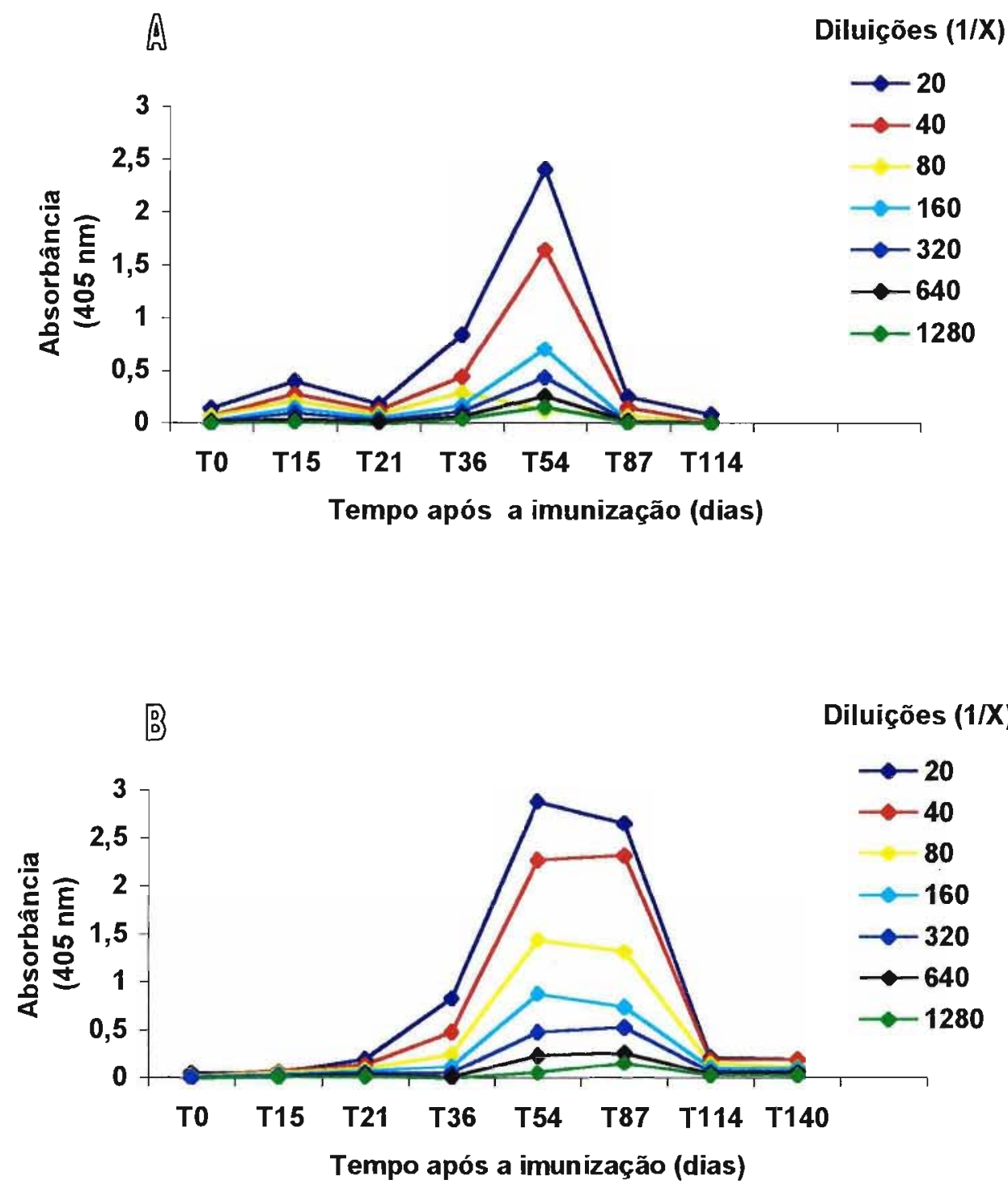

Figura 7 - Avaliação da cinética da produção de anticorpos das classes $\operatorname{lgM}(\mathrm{A})$ e IgG (B) dirigidos contra a fração protéica $7 S$ da soja, após a imunização de camundongos BALB/C.

TO - Tempo de coleta do sangue anterior à imunização.

Os dados são expressos como a média das análises em duplicata. 
A produção de anticorpos dirigidos contra a fração $11 S$ da soja mostrou uma resposta inicial de pequena intensidade, caracterizada pela presença de IgM no soro de camundongos, que ocorreu entre o $18^{\circ}$ e $43^{\circ}$ dia após a imunização dos animais. Entretanto, a produção de anticorpos $\lg G$ ocorreu do $18^{\circ}$ ao $90^{\circ}$ dia após a imunização, apresentando dois picos protéicos de grande intensidade, no $27^{\circ} \mathrm{e}$ $57^{\circ}$ dia (Figura 8 ).

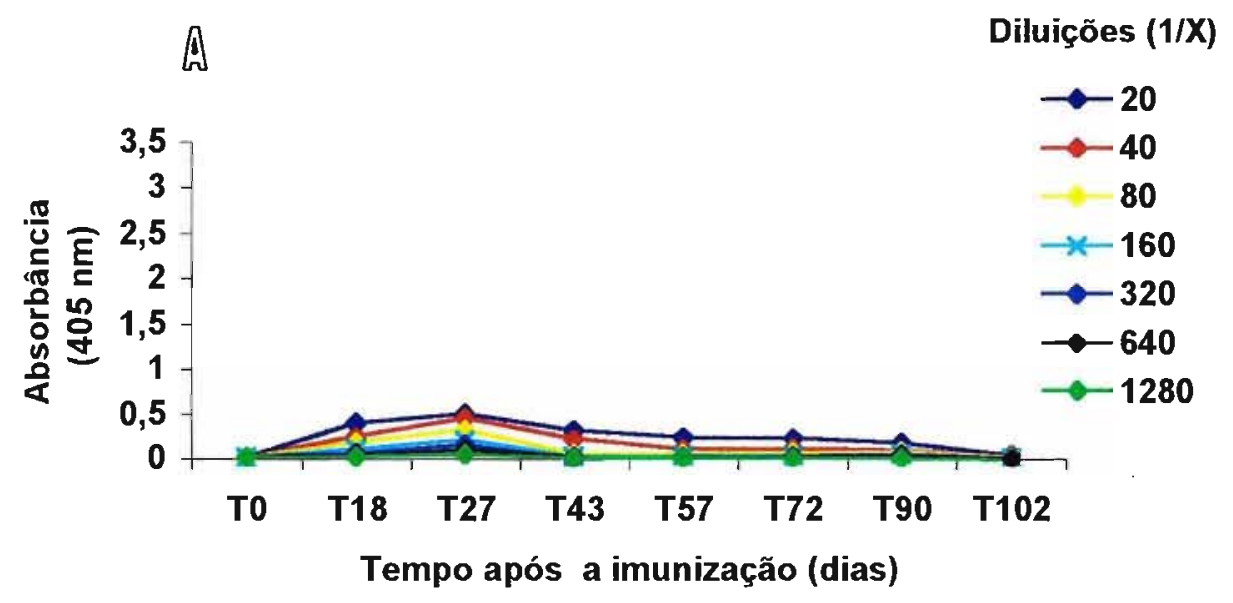




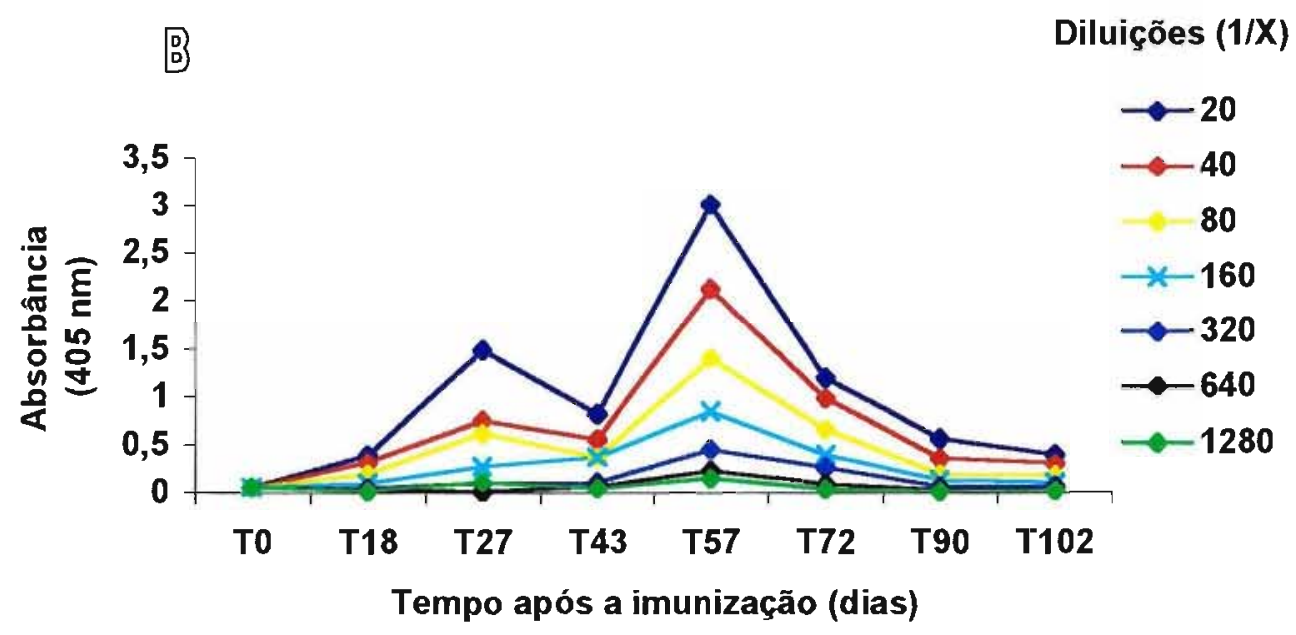

Figura 8 - Avaliação da cinética da produção de anticorpos das classes $\operatorname{lgM}(A)$ e $\lg$ (B) direcionados à fração protéica 11S da soja, após a imunização de camundongos BALB/C.

TO - Tempo de coleta do sangue anterior à imunização.

Os dados são expressos como a média das análises em duplicata.

\subsection{Avaliação do potencial alergênico das frações protéicas 2S, $7 S$ e 115 da} soja, pelo teste de Anafilaxia Cutânea Passiva (ACP)

Este experimento teve por objetivo investigar a capacidade das frações protéicas 2S, 7S e 11S da soja de induzirem a produção de anticorpos da classe IgE, em camundongos BALB/c imunizados, separadamente, (item 4.2) com essas proteínas. Após a imunização, esses animais foram sangrados, semanalmente, pelo plexo orbital e o sangue centrifugado a $800 \mathrm{~g}$ por $10 \mathrm{~min}$. O soro obtido de cada camundongo foi conservado a $-20^{\circ} \mathrm{C}$ até o dia do teste de ACP (item 4.6), quando se avaliou a presença de anticorpos IgE no soro desses animais, por intermédio da capacidade desses anticorpos de se ligarem aos mastócitos da derme de ratos Wistar. 
Os resultados obtidos com o teste de ACP demonstraram que os camundongos imunizados com as frações $2 S$ e $11 S$ da soja não produziram anticorpos IgE contra essas frações, uma vez que o diâmetro da lesão rıo dorso do rato foi inferior a $5 \mathrm{~mm}$, mesmo na menor diluição testada (1/5) e após uma semana do reforço (resultados não mostrados).

Com relação à fração protéica $7 \mathrm{~S}$ da soja, foi observado positividade ao teste de ACP somente na resposta secundária ( $\left.35^{\circ} \mathrm{dia}\right)$, isto é, fase de intensa produção de anticorpos $\operatorname{lgE}$, devido ao reforço administrado no $28^{\circ}$ dia após a imunização inicial. A reação positiva é evidenciada por uma mancha azulada no dorso dos ratos, com um diâmetro maior de $5 \mathrm{~mm}$.

A Figura 9 mostra o teste de ACP positivo induzido pela fração protéica 75 da soja, rıa resposta secundária. O diâmetro das reações foram $16 \mathrm{~mm}$ (soro puro), $15 \mathrm{~mm}(1 / 5), 14 \mathrm{~mm}(1 / 10), 12 \mathrm{~mm}(1 / 20), 9 \mathrm{~mm}(1 / 40)$ e $5 \mathrm{~mm}(1 / 80)$, estabelecendo-se 80 como título do teste, que correspondeu ao inverso da maior diluição que resultou em uma reação positiva, com mais de $5 \mathrm{~mm}$ de diâmetro (Figura 10). 


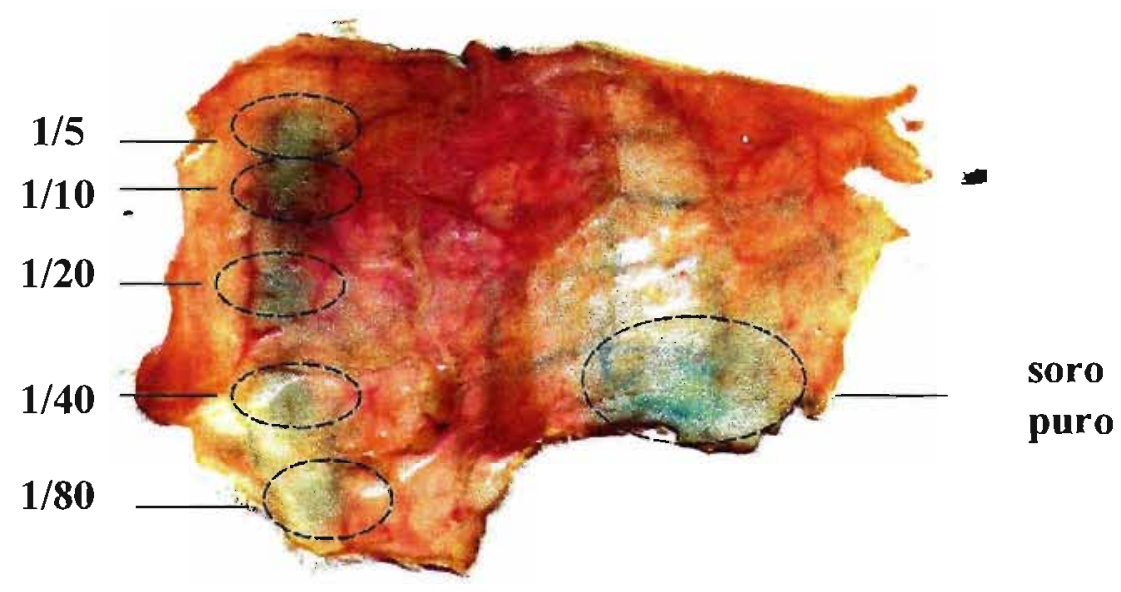

Figura 9 - Anafilaxia cutânea passiva induzida pela fração protéica $7 S$ da soja, em ratos Wistar, na resposta secundária ( $35^{\circ}$ dia após a imunização)

A reação dérmica de cor azul, com diâmetro acima de $5 \mathrm{~mm}$, representa positividade no teste de Anafilaxia Cutânea Passiva.

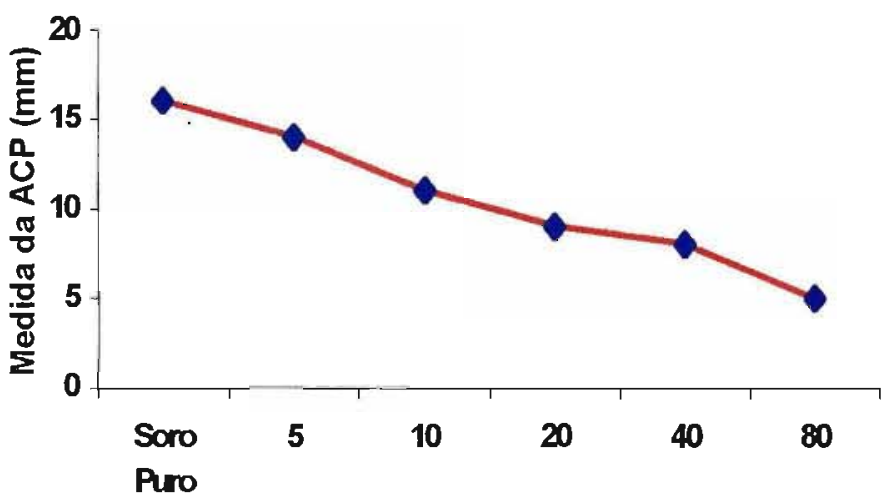

Diüçöes -1

Figura 10 - Avaliação da cinética da produção de anticorpos da classe IgE dirigidos contra a fração $7 S$ da soja, após imunização de camundongos BALB/c, no teste de Anafilaxia Cutânea Passiva.

Cada dado representa a média do diâmetro de três reações dérmicas, observadas em ratos Wistar. 


\subsection{Avaliação da presença de anticorpos $\operatorname{lgE}$ e IgG, reativos às frações} protéicas 2S, 7 e 11S, no soro de pacientes alérgicos à soja

Com o objetivo de avaliar a imunogenicidade e o potencial alergêrico das frações protéicas 2S, 7S e 11S da soja, na espécie humana, padronizou-se uma técnica de ELISA (item 4.7), investigando-se a presença de anticorpos das classes lgE e IgG no soro de pacientes alérgicos à soja.

Os resultados dessas análises demonstraram que o conteúdo de $\lg E$ anti frações protéicas, no soro dos pacientes alérgicos à soja, não diferiram do conteúdo de IgE encontradas no soro dos pacientes controles $\left[F_{2,24}=2.541 ; p>\right.$ 0,05]. Quando se analisou o soro dos pacientes alérgicos e controles, com seu respectivo branco, pelo teste de ANOVA univariada, não foi evidenciado significância estatística: $2 S\left[F_{2,9}=1.930 ; p>0,05\right], 7 S\left[F_{2,9}=2.826 ; p>0,05\right], 11 S$ $\left[F_{2,9}=0,3798 ; p>0,05\right] . A$ análise estatística entre as frações protéicas $2 \mathrm{~S}, 7 \mathrm{~S}$ e $11 \mathrm{~S}$ da soja, utilizando-se o soro de pacientes alérgicos, não mostrou diferença significante. As Figuras 11 e 12 mostram os resultados da análise de IgE no soro de pacientes alérgicos à soja e pacientes controles e da padronização da curva $\lg E$, respectivamente. 


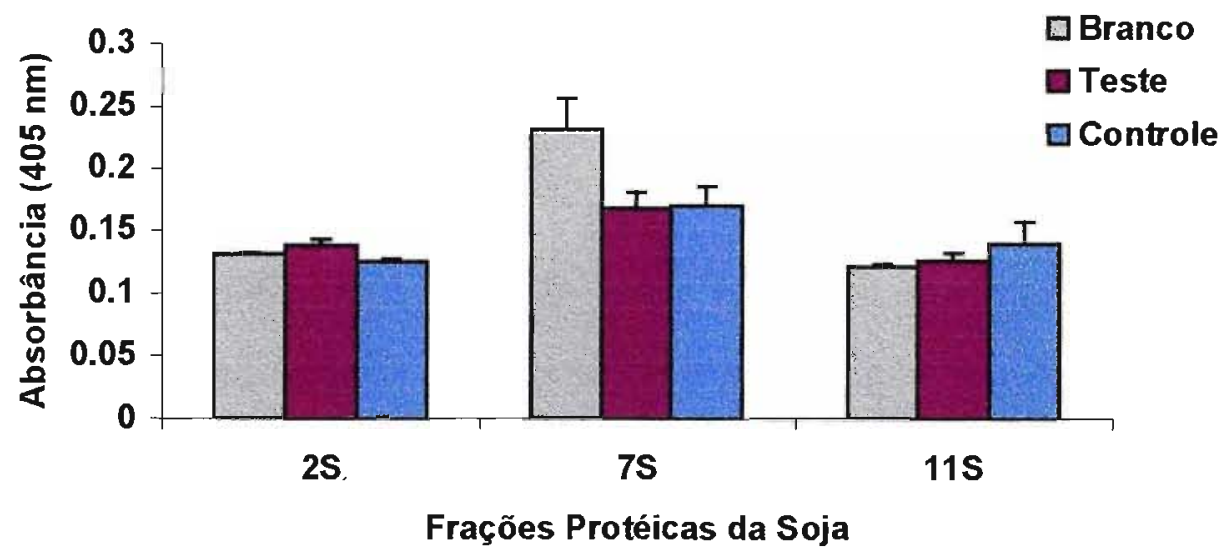

Figura 11 - Análise sérica de anticorpos IgE dirigidos contra as frações protéicas $2 S, 7 S$ e $11 \mathrm{~S}$, em pacientes alérgicos à soja e controles.

Os dados são expressos como a média \pm e.p.m. de 5 indivíduos (ANOVA univariada).

Teste e controle $=$ pacientes alérgicos e não alérgicos à soja, respectivamente

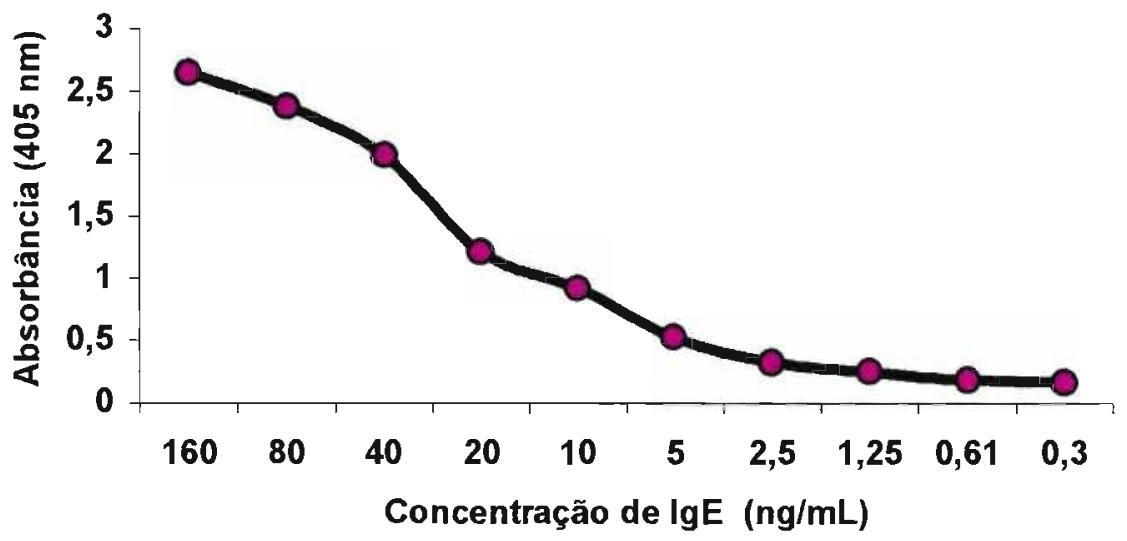

Figura 12 - Representação gráfica da curva padrão lgE, no teste de ELISA. Os valores são expressos como a média das análises em duplicata.

Valor de $\mathrm{R}^{2}=0,9797$. 
Com relação à análise sérica de anticorpos IgG, foi evidenciado significância estatística quando comparou-se o soro dos pacientes alérgicos e controles com o seu branco respectivo: $2 S\left[F_{2,15}=22.496 ; p<0,01\right], 7 S\left[F_{2,15}=25.466 ; p<0,01\right]$ (ANOVA univariada). Como era de se esperar, na análise posterior, teste de Dunnett, constatou-se que as frações protéicas $2 S$ e $7 S$ da soja possuem a capacidade de induzir a produção de anticorpos da classe lgG, na espécie humana. Por outro lado, quando se analisou a imunogenicidade da fração protéica $11 \mathrm{~S}$ da soja e, comparou-se os resultados dos grupos teste e controle com seu respectivo branco, observou-se que não houve diferença estatisticamente significante $\left[F_{2,15}=3.119 ; p>0,05\right]$. Da mesma forma, quando os resultados dos pacientes alérgicos à soja foram comparados com os dos pacientes controles, não houve diferença estatisticamente significante $\left[F_{5,24}=2.152 ; p>0.05\right]$ no teste ANOVA. A análise entre as frações protéicas 2S, 7S e 11S da soja, utilizando-se o soro de pacientes alérgicos, também não mostrou diferença estatística (Figura 13). 


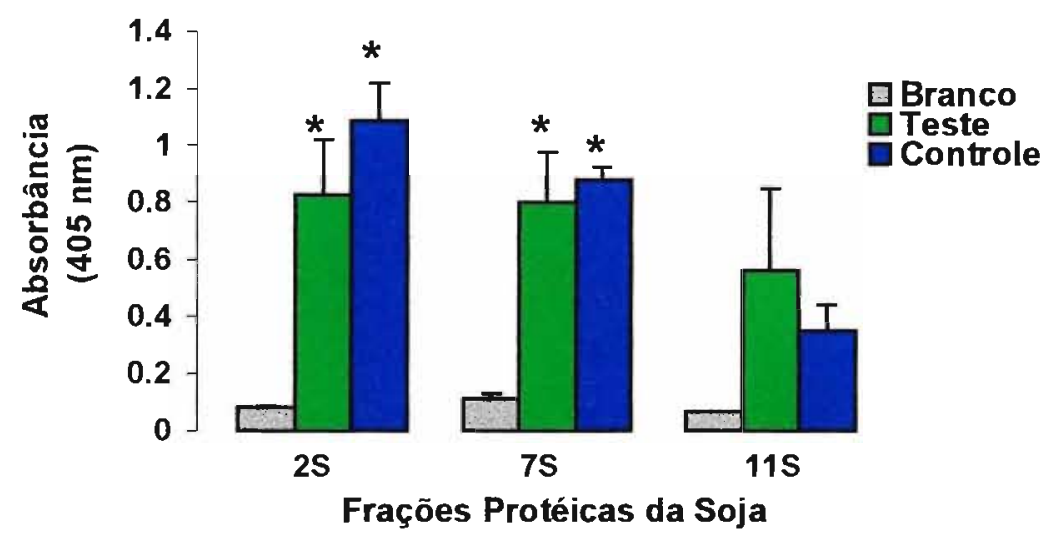

Figura 13 - Produção de anticorpos da classe IgG reativos às frações protéicas $2 S, 7 S$ e $11 S$ da soja, em pacientes alérgicos à soja.

Os dados são expressos como a média \pm e.p.m. de 5 indivíduos (ANOVA univariada).

${ }^{*} p<0,01$ em relação ao branco.

Teste e controle $=$ pacientes alérgicos e não alérgicos à soja, respectivamente. 


\subsection{Obtenção de anticorpos monoclonais dirigidos contra as frações} protéicas 7 e $11 S$ da soja

Quatro anticorpos monoclonais reativos às proteinas da soja foram obtidos e denominados de 1H4, 1F9, $2 \mathrm{~A} 8$ (7S) e 3F2 (11S) (Figuras 14 e 15).

\subsubsection{Clonagem dos anticorpos monoclonais direcionados às frações} protéicas 75 e 115 da soja

Os hibridomas foram clonados por diluição limitante. A reatividade dos anticorpos monoclonais dirigidos contra as frações protéicas 7S e 11S da soja foi analisada por ELISA. O título do sobrenadante dos hibridomas $1 \mathrm{H} 4$ e $2 \mathrm{~A} 8$ foi de 8000 , enquanto que o título do 3F2 foi de 12000 e do 1F9 de 10000 (Figura 16).

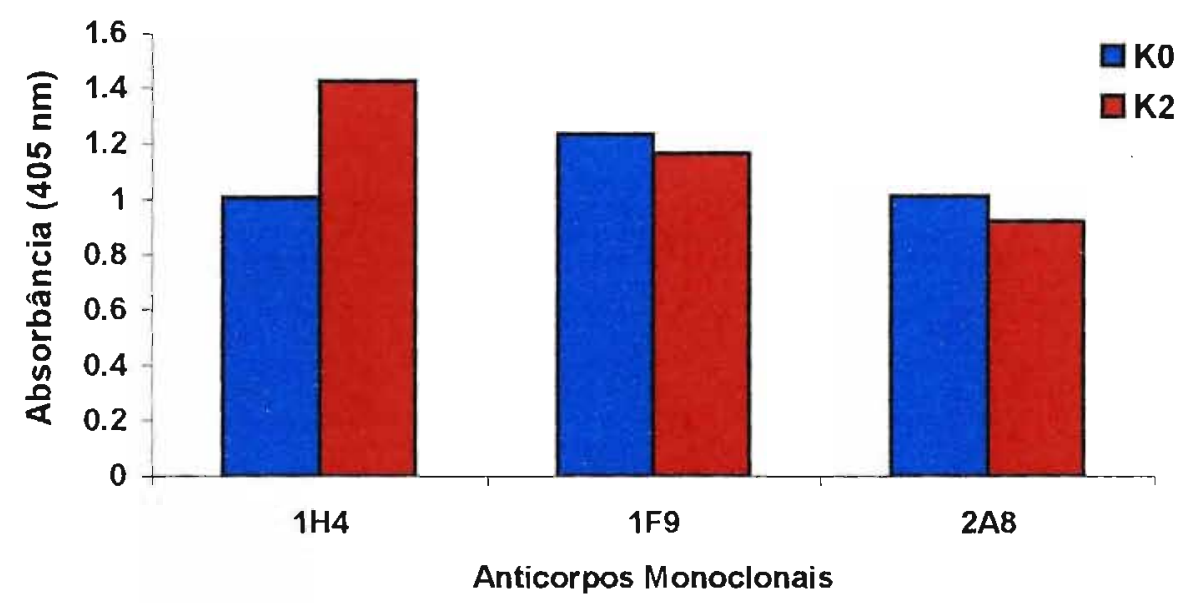

Figura 14 - Obtenção de anticorpos monoclonais dirigidos contra a fração protéica $7 S$ da soja.

Os dados são expressos como a média das análises em duplicata.

KO - hibridoma inicial

K2 - após clonagem e subclonagem 


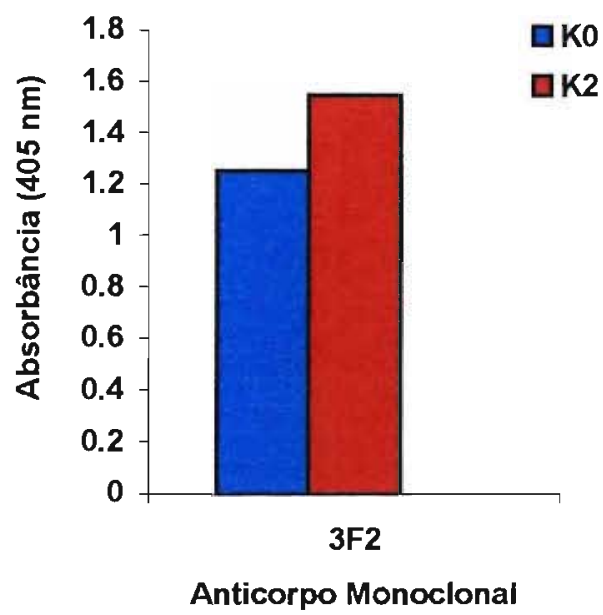

Figura 15 - Obtenção de anticorpo monoclonal dirigido contra a fração protéica $11 \mathrm{~S}$ da soja.

Os dados são expressos como a média das análises em duplicata.

$\mathrm{KO}$ - hibridoma inicial

K2 - após clonagem e subclonagem

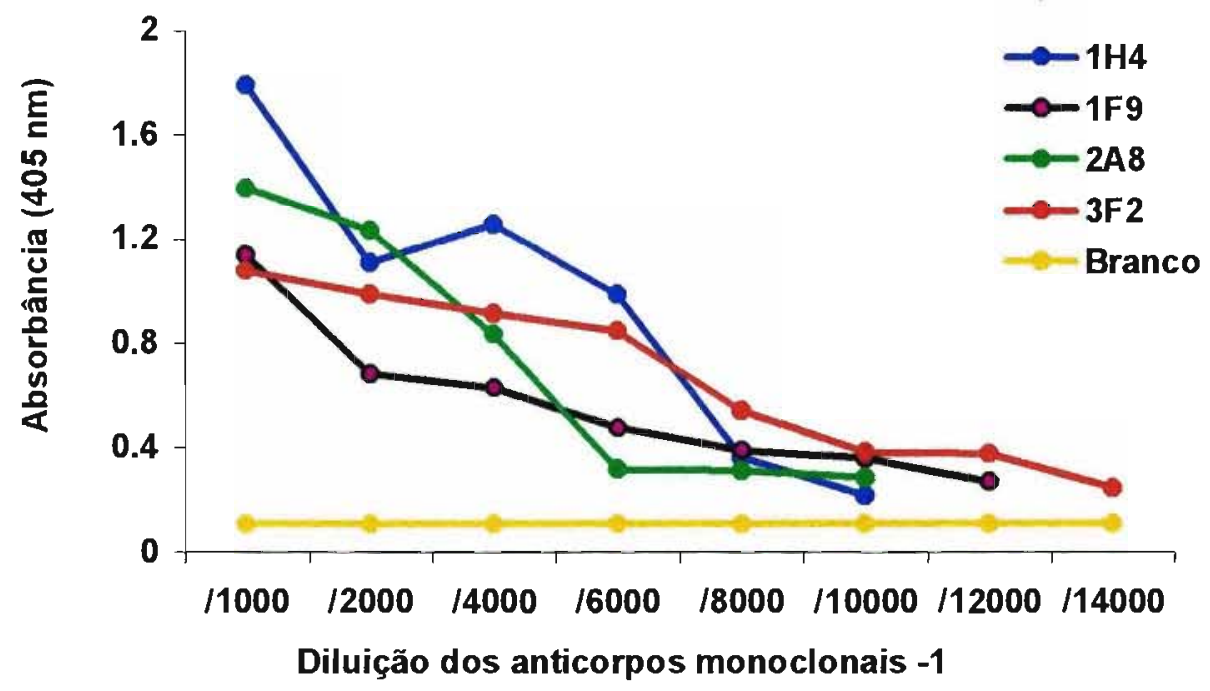

Figura 16 - Avaliação do limiar de reatividade dos anticorpos monoclonais direcionados às frações protéicas $7 S$ e 11 da soja, por ELISA.

Os dados são expressos como a média das análises em duplicata. 


\subsubsection{Isotipagem dos anticorpos monoclonais reativos às frações protéicas}

\section{$7 S$ e $11 S$ da soja}

Visando identificar os isotipos dos anticorpos monocionais reativos às frações protéicas $7 \mathrm{~S}$ e $11 \mathrm{~S}$ da soja, os sobrenadantes dos hibridomas produtores de anticorpos monoclonais foram analisados por ELISA (item 4.8.4), investigandose os isotipos de anticorpos IgG de camundongos lgG1, IgG2a, IgG2b, IgG3, além de $\lg A$ e $\lg M$.

Os resultados obtidos mostraram que os anticorpos monoclonais dirigidos à fração protéica $7 \mathrm{~S}$ da soja (1H4, $1 \mathrm{Fg}$ e 2A8), pertencem à classe de anticorpos $\lg G$, isotipo $\lg G 2 b$, enquanto que o monoclonal dirigido contra a fração $11 \mathrm{~S}$ da soja (3F2) pertence à classe IgG, isotipo IgG1 (Figura 17).

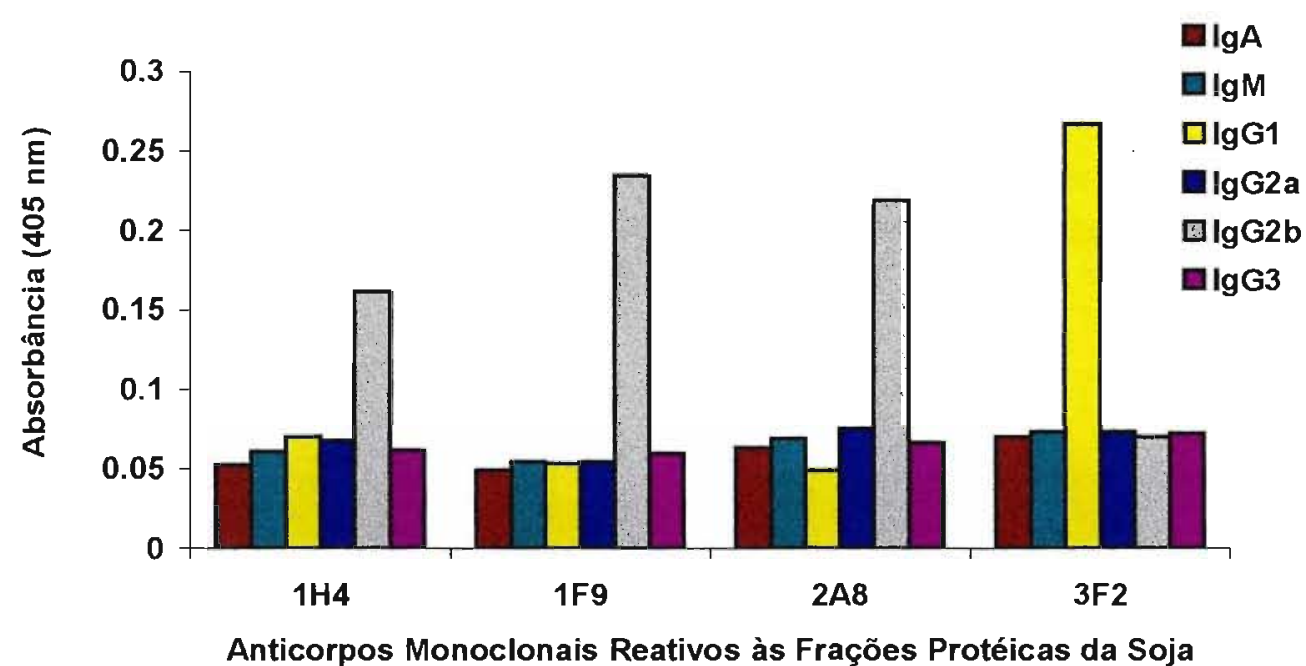

Figura 17 - Isotipagem dos anticorpos monoclonais reativos às frações protéicas $7 S$ e $11 S$ da soja, analisados por ELISA.

Os dados são expressos como a média das análises em duplicata. 


\subsubsection{Purificação dos anticorpos monoclonais dirigidos contra as frações} protéicas 7S e 11S da soja

O líquido ascítico, rico em anticorpos monoclonais, foi purificado em coluna de afinidade (Hitrap Protein A, Pharmacia Biotech). O perfil cromatográfico obtido desta purificação se encontra na Figura 18. Os anticorpos monoclonais 1F9, $1 \mathrm{H} 4 \mathrm{e}$ $2 \mathrm{~A} 8$ foram eluídos com o tampão glicina, $\mathrm{pH} 2,8$ enquanto que a eluição do anticorpo monoclonal 3F2 ocorreu com o tampão citrato, pH 5,5.

$1 F 9$

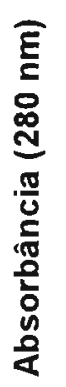

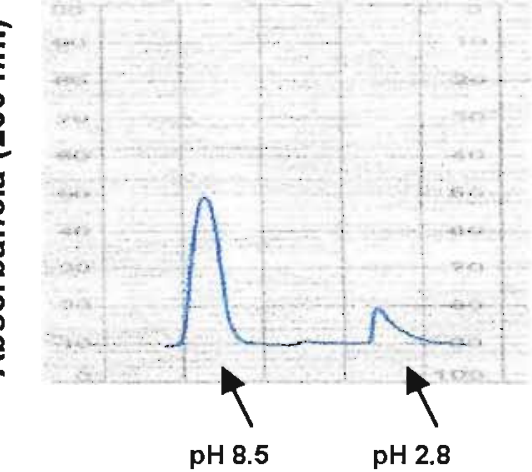

$1 \mathrm{H} 4$

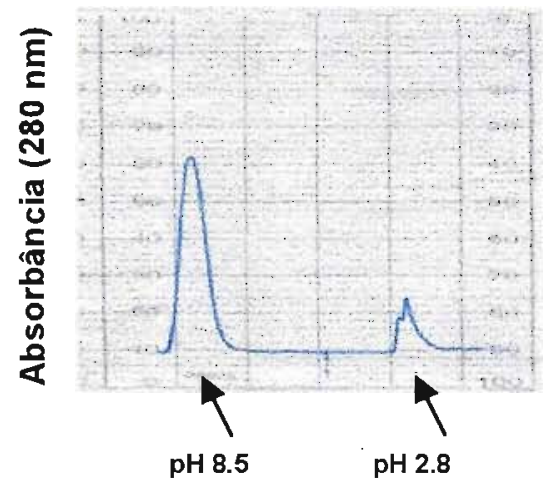

pH dos tampões utilizados na purificação dos anticorpos monoclonais

$2 \mathrm{AB}$

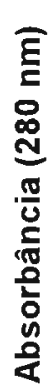

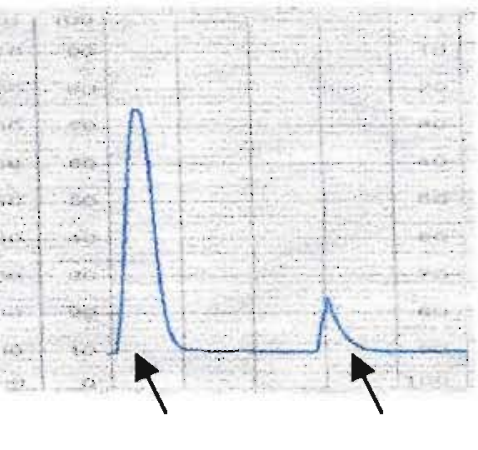

pH 8.5

$\mathrm{pH} 2.8$
3F2

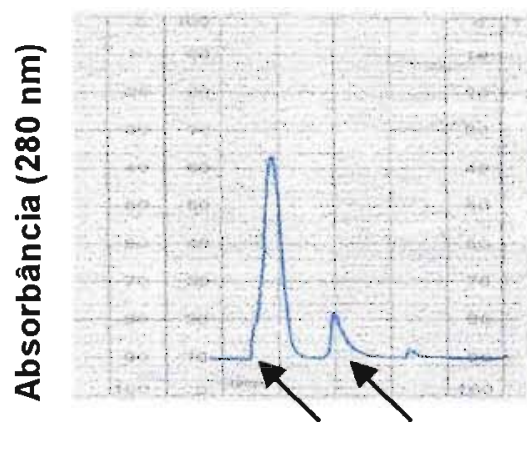

pH $8.5 \quad$ pH 5.5

pH dos tampões utilizados na purificação dos anticorpos monoclonais

Figura 18 - Purificação dos anticorpos monoclonais dirigidos contra as frações protéicas $7 \mathrm{~S}$ e $11 \mathrm{~S}$ da soja, após eluição pela coluna de proteína $\mathrm{A}$. 


\subsubsection{Análise da especificidade dos anticorpos monoclonais por} Imunotransferência

A especificidade dos anticorpos monoclonais foi analisada por Imunotransferência (item 4.8.10). Os resultados obtidos demonstraram que o anticorpo monoclonal reativo à fração protéica $11 \mathrm{~S}$ da soja reconheceu a banda protéica de peso molecular de $19 \mathrm{KDa}$, correspondente à subunidade básica da fração protéica $11 \mathrm{~S}$ da soja. Entretanto, os anticorpos monoclonais, reativos à fração protéica $7 S$ da soja, reconheceram diferentes determinantes antigênicos do extrato bruto da soja. Com relação à fração $7 S$ da soja, o anticorpo monoclonal $2 \mathrm{~A} 8$ reconheceu a subunidade $\beta$, correspondente ao peso molecular de $52,8 \mathrm{KDa}$, o anticorpo monoclonal $1 \mathrm{H} 4$ reconheceu a subunidade $\alpha^{\prime}$ e $\beta$, com pesos moleculares correspondentes a 77,57 e 52,8 KDa, enquanto que o anticorpo monoclonal 1F9 reconheceu as três subunidades $\alpha, \alpha^{\prime}$ e $\beta$ da fração protéica 7S da soja, com pesos moleculares de $80,4,77,57$ e 52,8 KDa, respectivamente. Todos os anticorpos monoclonais aqui descritos reconheceram epítopos lineares, visto que, na análise de Imunotransferência, reagiram apenas com as amostras de proteínas reduzidas com 2 mercaptoetanol. A Figura 19 mostra os resultados desse experimento. 


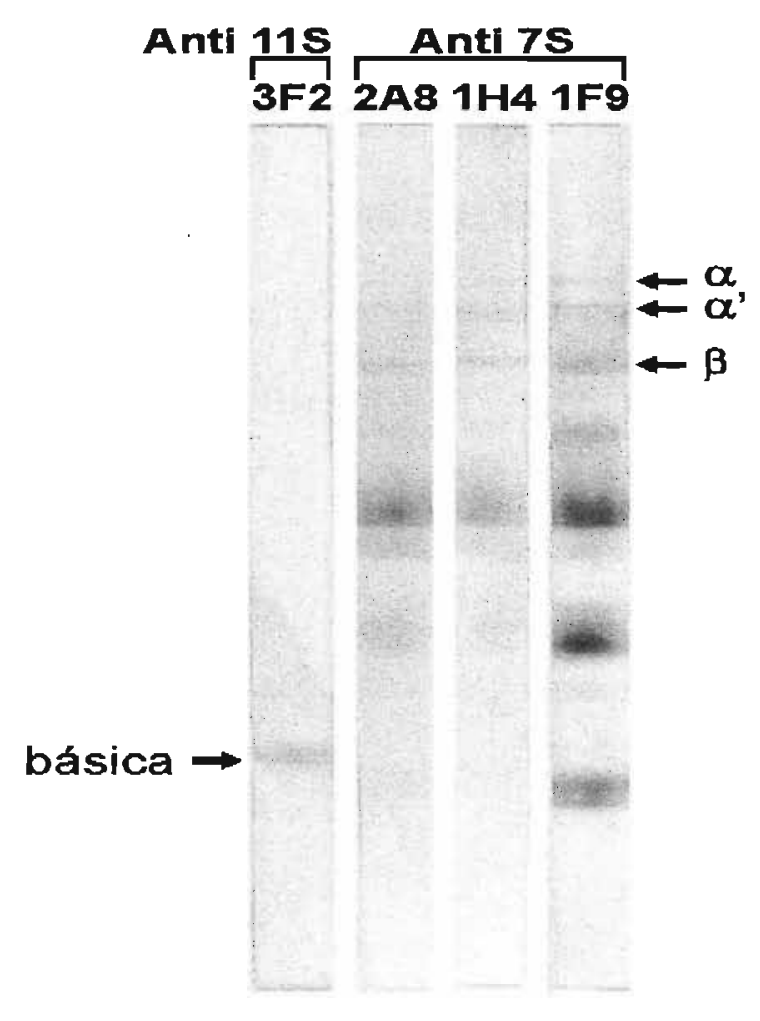

Figura 19 - Identificação dos determinantes antigênicos das frações protéicas da soja, reconhecidos pelos anticorpos monoclonais reativos às frações 7S (2A8, $1 \mathrm{H} 4,1 \mathrm{~F} 9$ ) e 11S (3F2), por Imunotransferência. 


\subsubsection{Deteç̧ão das proteínas da soja em produtos comercializados}

A realização deste protocolo experimental teve o propósito de investigar se os anticorpos monoclonais dirigidos contra as frações protéicas 7S e 11S da soja, reconhecem as proteínas de soja, presentes em alguns produtos comercializados, utilizando-se o ensaio ELISA. Como pode-se observar, os anticorpos monoclonais reconheceram proteínas presentes em diferentes produtos à base de soja tais como, iogurte Tonyu, extrato de soja Mupi, Nestogeno com $5 \%$ de soja, suco Ades e suco de laranja Soy Fruit, nas alíquotas contendo $1 \mu \mathrm{g}$ de proteína/poço (Figura 20). Esses mesmos anticorpos monoclonais, não reagiram com os produtos isentos de soja nas alíquotas contendo até $5 \mu \mathrm{g}$ de proteína/poço (dados não mostrados).

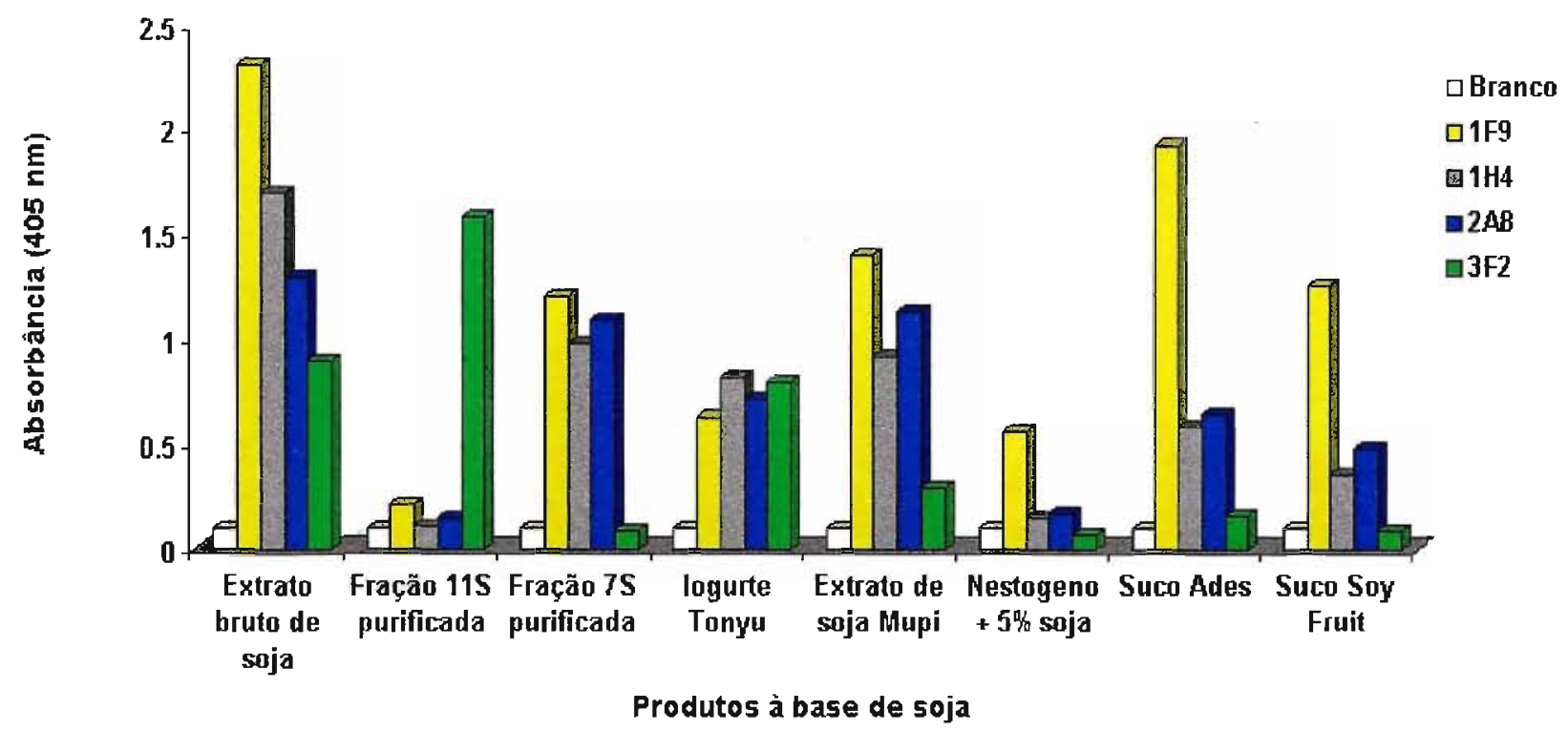

Figura 20 - Identificação das proteínas de soja, presentes em produtos comercializados, pelos anticorpos monoclonais $1 \mathrm{H} 4,2 \mathrm{~A} 8$, $1 \mathrm{~F} 9$ e $3 \mathrm{~F} 2$, no teste de ELISA.

Os dados são expressos como a média das análises em duplicata. 


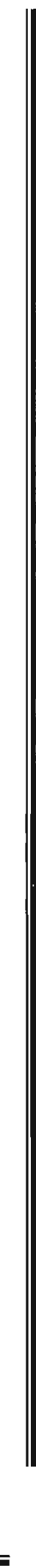




\subsection{DISCUSSÃO}

A seguir serão discutidas as possiveis implicações dos resultados, conforme a seqüência do delineamento experimental efetuado: extração e purificação das frações protéicas $2 S, 7 S$ e $11 S$ da soja; produção de anticorpos policlonais das classes $\lg M$, IgG e lgE, direcionados à essas frações, em camundongos BALB/c; avaliação da presença de anticorpos lgE e $\lg G$ reativos às frações protéicas da soja, no soro de pacientes alérgicos à essa leguminosa; produção de anticorpos monoclonais dirigidos contra as frações 7S e 11S da soja; detecção de proteínas de soja em produtos comercializados, utilizando-se os anticorpos monoclonais obtidos neste estudo.

A partir do isolado protéico da soja, a fração $7 S$ foi extraída com base nas diferentes solubilidades, em pHs distintos, e purificada utilizando-se cormatografia de afinidade. O monitoramento do procedimento de purificação foi feito por SDSPAGE, constatando-se o isolamento das subunidades $\alpha, \alpha^{\prime}$ e $\beta$, cujas massas moleculares corresponderam a $63,17,58,06$ e $42,09 \mathrm{KDa}$, respectivamente (Figura 3). Esses resultados estão de acordo com GARCIA et al., 1997, que descreveram as massas moleculares dessas subunidades como: $\alpha(57-76 \mathrm{KDa})$, $\alpha^{\prime}(57-83 \mathrm{KDa})$ e $\beta(42-53 \mathrm{KDa})$.

As frações protéicas $2 S$ e $11 S$ foram isoladas a partir da farinha desengordurada de soja. Após as diversas etapas de purificação, constatou-se por SDS-PAGE a presença de duas grandes bandas protéicas, cujas massas moleculares foram de $38,8 \mathrm{KDa}$ e $21,04 \mathrm{KDa}$, correspondentes às subunidades ácida e básica da fração 11 da soja, respectivamente (Figura 4). Conseguiu-se 
também purificar a fração $2 S$, obtendo uma fração única com massa molecular de 20 kDa Esses resultados estão de acordo com dados da literatura, que indicam massas moleculares das subunidades ácida e básica da fração 11 S entre 34 - 45 KDa e 19 - 22 KDa, respectivamente. Da mesma forma, é relatado que a fração $2 S$ da soja possui uma massa molecular de 20 KDa (BROOKS \& MORR, 1985; GARCIA et al., 1997). Após a purificação dessas três frações protéicas da soja, utilizou-se essas amostras nos ensaios in vivo e in vitro para se investigar a alergenicidade e imunogenicidade dessas frações protéicas.

Um dos aspectos mais interessantes e relevantes observados neste estudo, foi a obtenção da cinética de produção de anticorpos das classes $\lg M$ e $\lg G$, induzidos pelas proteínas da soja, em camundongos (Figuras 6-8). Não há dados na literatura sobre a imunização de camundongos com esse propósito, embora haja alguns estudos demonstrando a presença de anticorpos $\lg G$ e $\lg E$ dirigidos contra as frações protéicas da soja, em soros de pacientes alérgicos à essa leguminosa (SHIBASAKI et al., 1980; BURKS et al., 1988; BURKS et al., 1991).

Os resultados mostraram que a fração protéica $7 S$ da soja induziu uma resposta de grande intensidade com relação à produção de anticorpos IgM (pico protéico no $54^{\circ}$ dia) e lgG (pico protéico entre o $54^{\circ}$ e $87^{\circ}$ dia) (Figura 7 ), enquanto que a fração protéica $11 \mathrm{~S}$ da soja apresentou esse tipo de resposta apenas com relação à produção de anticorpos IgG (pico protéico entre $018^{\circ}$ e $90^{\circ}$ dia), visto que na análise da resposta humoral $\lg M$, observou-se um pico de pequena intensidade do $18^{\circ}$ ao $43^{\circ}$ dia, após a imunização dos camundongos (Figuras 8 ).

Por outro lado, quando se avaliou a produção de anticorpos $\lg M$ e $\lg G$ dirigidos contra a fração protéica $2 S$ da soja, não foi evidenciada nenhuma 
resposta IgM na fase precoce da resposta imuológica, porém, na fase tardia, houve uma pequena produção de anticorpos, principalmente no $30^{\circ}$ dia após a imunização dos animais (Figura 6). Com base nos dados acima relatados, é possivel sugerir que as frações protéicas $7 S$ e $11 S$ da soja são imunogênicas em camundongos BALB/c, enquanto que a fração $2 S$ da soja parece não possuir a capacidade de estimular o sistema imunológico dos animais para produzir anticorpos da classe IgM.

A imunogenicidade e alergenicidade das proteínas da soja é um tema discutido por muitos pesquisadores, entretanto não se conseguiu, ainda, estabelecer qual a fração protéica da soja é a mais alergênica.

SHIBASAKI et al., 1980, usando os testes RAST e inibição do RAST, em pacientes atópicos, observaram que as frações $2 S$, 7 S e 11 S reagiram com a IgE específica, porém a fração $2 S$ apresentou alto potencial alergênico para inibir o RAST, quando comparada às outras frações. Contudo, em um estudo posterior desenvolvido por OGAWA et al., 1991, foi demonstrado que a fração 7 S contém o prinicpal componente alergênico.

BURKS et al., 1988, investigaram em oito pacientes com dermatite atópica e teste de intolerância oral positivo, a especificidade alergênica dos anticorpos lgE e IgG à fração bruta das proteinas da soja e às frações 7 e 11S, utilizando o teste imunoenzimático (ELISA). Os resultados indicaram que tanto a IgE quanto a IgG, específicas à fração bruta da soja, estão elevadas em pacientes com teste de provocação oral positivo, mas não foi possível identificar, claramente, qual a fração protéica mais alergênica. 
BURKS et al., 1989, avaliaram a resposta dos anticorpos lgE e lgG específicos à soja e às suas frações, em pacientes intolerantes à soja, utilizando as técnicas de ELISA e Imunotransferência. Os dados obtidos não mostraram diferença estatisticamente significante entre o grupo challenge positivo (suspeitos de intolerância à soja, confirmados com a administração oral) e o grupo challenge negativo, não sustentando a hipótese de que crianças intolerantes possam ser sensibilizadas sistemicamente. Da mesma forma, os experimentos realizados por Imunotransferência não demonstraram diferenças de imunogenicidade entre as frações protéicas da soja.

PASCHKE et al., 2001, investigaram a capacidade dos anticorpos $\lg E$ de humanos, específicos ao extrato de soja, de se ligarem à lecitina de soja e óleo de soja bruto e refinado. Nesse estudo constatou-se que o conteúdo protéico do óleo refinado, óleo bruto e lecitina de soja foi em torno de $33,2 \mu \mathrm{g} / \mathrm{kg}, 100 \mu \mathrm{g} / \mathrm{kg}$ e 2,5 $\mathrm{mg} / \mathrm{kg}$, respectivamente. Na análise por Imunotransferência não se observou a ligação da IgE com as proteínas do óleo refinado, enquanto que essa resposta foi evidenciada, levemente, com o óleo não refinado, caracterizando as bandas protéicas de, aproximadamente, 53 e $58 \mathrm{KDa}$. Por outro lado, com a lecitina de soja, ocorreu a ligação da IgE com uma proteína de massa molecular de 16 KDa, confirmando os resultados obtidos por CODINA et al., 1998, que encontraram alérgenos com massas moleculares de 14 e $16 \mathrm{KDa}$.

BURKS et al., 1991 avaliaram os alérgenos protéicos da soja, utilizando o extrato bruto, frações do soro e frações protéicas $7 S$ e $11 S$ da soja, em oito pacientes com dermatite atópica e teste de intolerância oral positivo. Também 
investigaram as possíveis alterações dessas proteínas, com relação à imunogenicidade, após o processo de aquecimento e desnaturação. Os resultados demonstraram que as crianças com dermatite atópica e teste de intolerância oral positivo possuem níveis elevados de $\lg E$ e $\lg G$, que reagem com o extrato bruto protéico e com as frações protéicas da soja. Os dados obtidos também evidenciaram a presença de IgE anti-fração $7 S$, enquanto que os anticorpos IgG reagiram com a fração $11 \mathrm{~S}$ da soja, no teste de ELISA. O processo de aquecimento $\left(120^{\circ} \mathrm{C}\right)$ das proteínas diminuiu, significativamente, a ligação dos anticorpos lgE e IgG com o extrato bruto, frações do soro e frações protéicas 7S e 11 da soja, da mesma forma que o tratamento enzimático reduziu a ligação de IgE com essas proteínas.

No presente estudo, tentou-se definir, claramente, qual seria a fração mais alergênica da proteína da soja, investigando-se a capacidade das frações $2 S, 7 S$ e 11S de estimular a produção de anticorpos $\lg E$ em camundongos BALB/C, por intermédio do teste de ACP e na espécie humana, avaliando-se a presença desses anticorpos no soro de pacientes alérgicos à soja.

Os resultados obtidos no teste de ACP demonstraram que a fração protéica $7 S$ da soja induziu a produção de anticorpos da classe $\operatorname{lgE}$, visto que houve desgranulação de mastócitos, visualizado pela reação de cor azul acima de $5 \mathrm{~mm}$ de diâmetro, na pele invertida de ratos Wistar (Figura 9). A resposta foi evidenciada na fase secundária ( $35^{\circ}$ dia após a imunização), onde há grande produção de anticorpos, devido ao reforço administrado no $28^{\circ}$ dia após a imunização, obtendo-se valores de $15,14,12,9,8$ e $5 \mathrm{~mm}$ de diâmetro, correspondentes ao soro puro e às diluições entre 1/5 e 1/80 (Figura 10). Assim 
sendo, os resultados alcançados indicam que a fração $7 S$ da soja é alergênica, nesse modelo experimental.

Curiosamente, quando os camundongos BALB/c foram imunizados com as frações protéicas $2 S$ e $11 \mathrm{~S}$ da soja, não foi observada nenhuma reação de cor na pele invertida de ratos. Como já está bem estabelecido, que para ocorrer a sensibilização dos mastócitos na pele desses animais, é necessário que o soro administrado, intradermicamente, possua anticorpos da classe lgE, os resultados obtidos sugerem que as frações $2 S$ e $11 S$ da soja não possuem a capacidade de estimular o sistema imunológico de camundongos a produzir essa classe de anticorpos (dados não mostrados).

O estudo realizado por SHIBASAKI et al., 1980, utilizando o teste de ACP para avaliar a alergenicidade das proteínas da soja, mostrou resultados conflitantes com os dados obtidos neste estudo. Neste trabalho, foi observado que a fração $2 S$ da soja induziu a produção de anticorpos lgE (título ACP 160), enquanto que a fração $7 \mathrm{~S}, 11 \mathrm{~S}$ e a fração globulina total não promoveram esse tipo de resposta. Sabendo-se que a fração globulina total possui todas as frações protéicas da soja, seria de se esperar que essa amostra também estimulasse o sistema imunológico de camundongos a produzir anticorpos $\operatorname{lgE}$. No entanto, os autores argumentam que essa ausência de resposta pode ser devido à competição antigênica ou à presença de fatores inibitórios nessa amostra. Por outro lado, OGAWA et al., 1991, mostraram uma baixa imunogenicidade da fração do soro da soja, onde a fração $2 S$ está presente. Entretanto, vale a pena ressaltar que as doses utilizadas em nosso estudo [50 $\mu \mathrm{g}$ e $5 \mu \mathrm{g}$ (reforço)] foram distintas 
das usadas por SHIBASAKI et al., $1980(10 \mu \mathrm{g}$ e $1 \mu \mathrm{g})$ e, sendo assim, é possível sugerir que essa diferença metodológica possa ter grande relevância na obtenção dos resultados obtidos em nosso estudo.

$A$ avaliação da presença de anticorpos $\lg E$ e $\lg G$, reativos às frações $2 S, 7 S$ e 11S, no soro de pacientes alérgicos à soja foi realizada por um ensaio imunoenzimático, com as frações protéicas purificadas, adsorvidas na placa de ELISA. Nessa avaliação, utilizou-se cinco soros de pacientes alérgicos ao leite de vaca, sendo três deles alérgicos, simultaneamente, ao leite de vaca e à soja (grupo verdadeiramente positivo), comprovados com história clínica de intolerância a esses alimentos e RAST, Prick Test ou Teste de provocação oral positivos à soja. Dos cinco pacientes controles, quatro são indivíduos com quadro clínico de asma e rinite e sem nerıhuma história de alergia alimentar e Prick Test negativo ao leite de vaca e soja, e um paciente não tem história de nenhum tipo de alergia (item 11.1).

Os resultados da análise do potencial alergênico das frações $2 S, 7 S$ e $11 S$ da soja, na espécie humana, sugerem que os soros dos pacientes alérgicos à soja não apresentavam anticorpos IgE específicos a essas frações protéicas (Figura 11). Esses dados parecem refletir uma resposta consistente, visto que a curva IgE mostrou um resultado satisfatório, utilizando-se os mesmos parâmetros metodológicos $\left(R^{2}=0,9797\right)$ (Figura 12).

Por outro lado, quando se investigou a capacidade das frações protéicas $2 S$, $7 S$ e $11 S$ da soja reagirem com anticorpos da classe IgG do soro de pacientes alérgicos, observou-se reatividade com todos os individuos alérgicos e controles 
para as frações $2 S$ e $7 S$ da soja, indicando que essas frações protéicas são imunogênicas na espécie humana (Figura 13). Entretanto, os resultados obtidos com a fração $11 \mathrm{~S}$ da soja não mostraram significância estatística, quando comparou-se os dados dos pacientes alérgicos e controles com o branco. Isso, pode ser o reflexo dos resultados individuais discrepantes obtidos com a fração $11 \mathrm{~S}$ da soja, no teste de ELISA. Nesse caso, observou-se resultados negativos com dois pacientes alérgicos e dois controles, enquanto, que o soro de dois indivíduos do grupo teste e um do controle mostraram a presença de um alto conteúdo de IgG específico à essa fração protéica. Vale a pena ressaltar que na análise da presença de anticorpos lgG no soro de pacientes alérgicos, um deles mostrou grande reatividade às frações protéicas $2 S, 7 S$ e $11 S$ da soja, simultâneamente (ítem 11.2).

Para excluir a possibilidade de adsorção de $\lg E$ não específica à proteína alimentar em estudo, é comum a utilização de um grupo controle com alergia a outros componentes alergênicos (SHIBASAKI et al., 1980; AWAZUHARA et al., 1997). Nesse contexto, o presente estudo não evidenciou esse tipo de resposta, devido à negatividade dos resultados obtidos com o soro de pacientes controle.

Com relação à análise de IgE, específica às frações protéicas $2 S, 7 S$ e $11 S$ da soja, em pacientes alérgicos e controles, há dados na literatura relatando inúmeras discrepâncias entre os resultados de diferentes testes de alergia. GIAMPIETRO et al., 1992, investigaram a sensibilização humoral (IgE específica) e clínica (teste positivo de intolerância oral à soja) em 317 crianças com dermatite atópica, além de história e sintomas sugestivos de alergia alimentar. Nesse estudo, os autores evidenciaram a prevalência de $22 \%$ para a sensibilização 
humoral e de $3 \%$ para a sensibilização clínica, confirmando os dados obtidos por SAMPSON et. al, 1985, que registraram uma prevalência de alergia à soja de $5 \%$, em crianças com dermatite atópica. No desenvolvimento do trabalho de GIAMPIETRO, observou-se que apenas 69 crianças tiveram um RAST positivo à soja, porém, somente cinco delas apresentaram positividade ao teste de intolerância oral. Por outro lado, cinco crianças com RAST negativo à soja, mostraram resposta positiva ao teste de intolerância oral. Observou-se, também, que houve uma significante correlação entre altos niveis de IgE total e RAST positivo à soja.

Sabendo-se que o RAST 'a soja tem uma sensibilidade de $66 \%$, especificidade de $80 \%$, valor preditivo negativo de $79 \%$ e valor preditivo positivo de $10 \%$, acredita-se que os resultados falso positivos para IgE podem ser devido às impurezas no extrato alergênico, ligações não específicas de $\lg E$, altos níveis de IgE e à presença de lgE sem relevância clínica (GIAMPIETRO et al., 1992). Também foi relatado que a presença de anticorpos IgG, com a mesma especificidade ao alérgeno, que estimulou a produção de anticorpos $\lg E$, podem interferir na análise, favorecendo uma falsa ligação à $\lg E$ por intermédio da formação do imunocomplexos IgE-lgG (BUSINCO et al., 1992). No entanto, esse processo não afetou os nossos resultados, visto que os dez soros testados (5 testes e 5 controles) deram resultados negativos para a IgE específica às frações $2 S, 7 S$ e $11 S$ da soja, após a reabsorção de $\lg G$ do soro pelo Rf-Absorbent. Considerando o pequeno número de pacientes estudados, há uma grande possibilidade de obtenção de resultados contraditórios nos diferentes testes, 
anteriormente citados (RAST negativo com teste de intolerância oral positivo), não excluindo-se portanto, a alergenicidade à soja nesses indivíduos.

Com relação aos resultados obtidos nas análises de IgG dirigidas contra as frações protéicas $2 S, 7 S$ e $11 S$ da soja, há relatos na literatura que citam a importância do subtipo lgG4 nas doenças alérgicas. Alguns pesquisadores registraram que a IgG4 atua como um anticorpo anafilático (PARISH, 1981), enquanto que outros o descrevem como um anticorpo bloqueador (VAN DER ZEE et al., 1986; NAKAGAWA, 1991), evidenciando-se um pico de produção entre 4 e 5 anos de idade (MOROI, 1988). Dessa forma, acredita-se que a produção de IgG4 é suprimida em torno das últimas fases da infância, quando a quantidade de antígeno, entrando no trato intestinal, é reduzida com a maturação da função do trato digestivo. Além disso, foi demonstrado nesse trabalho que há um aumento na produção de IgG4 após a terapia de dessensibilização. Em um estudo realizado por AWAZUHARA et al., 1997, analisando o soro de sete pacientes alérgicos à soja, observou-se que os anticorpos $\lg G 4$ e $\lg E$ não foram produzidos em resposta aos mesmos alérgenos protéicos, sendo assim, difícil de considerar que o anticorpo lgG4 atua como um anticorpo bloqueador, pelo menos nas reações alérgicas mediadas por lgE. Outra observação interessante, evidenciada nesse estudo, foi a presença de uma elevada reação para IgG4 com cinco pacientes (teste de intolerância oral positiva), dentre eles, três mostrando uma reação lgE muito fraca, sugerindo um envolvimento pequeno de $\operatorname{lgE}$ em seus sintomas alérgicos. Os autores descrevem que esses achados podem indicar a possibilidade de o anticorpo lgG4, específico à soja, atuar como um anticorpo anafilático. 
Da mesma forma, STANWORTH \& SMITH, 1970 observaram que os anticorpos lgG4 possuem a capacidade de inibir a reação de ACP, mediada por $\operatorname{lgE}$, por um tempo relativamente curto (menos de 24 horas), quando administrados em doses relativamente altas $(100 \mu \mathrm{g})$ na pele de babuínos, 4 horas antes da administração do soro de indivíduo sensibilizado com o pólen, contendo anticorpos $\operatorname{lgE}$. Os autores sugerem que os anticorpos anafiláticos IgG4 estão envolvidos, de alguma forma, nas reações de hipersensibilidade do tipo imediata.

Os resultados do presente estudo estão de acordo, parcialmente, com os relatos de AWAZUHARA et al., 1997, que demonstraram a presença de quantidade elevada de anticorpos IgG dirigidos contra as frações $2 S$ e $7 S$ da soja, na ausência de anticorpos lgE. Diante disso, é possivel sugerir que há uma grande possibilidade dos pacientes alérgicos, testados neste trabalho, terem induzido a produção de anticorpos lgG4 anafiláticos específicos às proteínas da soja, enquanto que o grupo controle possa ter produzido outro isotipo de anticorpo, específico à soja, porém, não relacionado com reações alérgicas à essa leguminosa.

Considerando a importância da padronização de um ensaio imunoenzimático que detecte proteínas de soja em produtos comercializados, foram produzidos três anticorpos monoclonais dirigidos contra a fração protéica $7 S$ e um anticorpo monoclonal reativo à fração 11S da soja (Figuras 14 e 15).

$\mathrm{Na}$ análise da especificidade dos anticorpos monoclonais, por Imunotransferência, foi observado que o anticorpo monoclonal direcionado à fração 11S da soja (3F2) reagiu, apenas, com a subunidade básica dessa 
proteína, enquanto que os anticorpos monoclonais dirigidos contra a fração 7S, mostraram reatividade com as subunidades $\alpha$, $\alpha^{\prime}$ e $\beta$ (1F9), $\alpha^{\prime}$ e $\beta(1 \mathrm{H} 4)$ e $\beta(2 \mathrm{~A} 8$ ), além de outras proteinas presentes no extrato bruto da soja (Figura 19).

Quando se avaliou o limiar de reatividade desses anticorpos às frações da soja, evidenciou-se uma reação positiva, no teste de ELISA, obtendo-se o título de 8000 para os anticorpos monoclonais $2 \mathrm{~A} 8$ e $1 \mathrm{H} 4,10000$ para o anticorpo $1 \mathrm{~F} 9 \mathrm{e}$ 12000 para o anticorpo monoclonal 3F2 (Figura 16), demonstrando que esses anticorpos monoclonais são muito reativos às proteínas da soja e, portanto, podem ser utilizados em diferentes ensaios biológicos.

Após a eluição dos picos protéicos da coluna de proteína $A$, durante $o$ processo de purificação dos anticorpos monoclonais, o perfil cromatográfico obtido (Figura 18), mostrou-se compatível com a análise de isotipagem por ELISA (Figura 17), na qual se constatou os isotipos de $\lg G$ aos quais pertenciam os anticorpos monoclonais reativos às frações $7 \mathrm{~S}$ e $11 \mathrm{~S}$ da soja. Nesse contexto, a análise por ELISA, demonstrou que os anticorpos monoclonais $1 \mathrm{H} 4,1 \mathrm{~F} 9$ e $2 \mathrm{~A} 8$ pertencem à classe $\lg G$, isotipo $\lg G 2 b$, enquanto que o anticorpo monoclonal $3 F 2$ pertence ao isotipo $\lg G 1$.

Além dessas análises, padronizou-se um ensaio imunoenzimático com o objetivo de investigar a reatividade desses anticorpos monoclonais às proteínas da soja, presentes em produtos comercializados. Os resultados obtidos demonstraram que os anticorpos monoclonais $1 \mathrm{H} 4,1 \mathrm{~F} 9,2 \mathrm{~A} 8$ e $3 \mathrm{~F} 2$, reconheceram as proteínas da soja nos alimentos analisados (Figura 20), entretanto, não reagiram com os alimentos isentos de proteínas da soja (dados 
não mostrados). Esses resultados apontam os anticorpos monoclonais, reativos às frações $7 \mathrm{~S}$ e $11 \mathrm{~S}$ da soja, como uma excelente ferramenta a ser empregada em procedimentos experimentais com diferentes propósitos, inclusive servindo como controle de qualidade para a indústria de alimentos, que visa fornecer ao mercado produtos à base de soja, isentos da fração alergênica. 


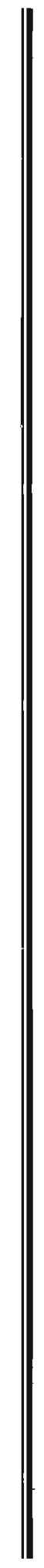

7.0 Conclusões 


\subsection{CONCLUSÕES}

- A purificação das frações protéicas $2 S, 7 S$ e $11 S$ da soja foi satisfatória, uma vez que a análise por eletroforese em gel de poliacrilamida constatou a presença das bandas protéicas, características de cada fração;

- As frações protéicas $7 S$ e $11 S$ da soja foram imunogênicas em camundongos, entretanto, a fração protéica $2 S$ induziu uma resposta IgG de pequena intensidade nesses animais;

- A fração protéica 7S da soja mostrou ser alergênica no teste de anafilaxia cutânea passiva, enquanto, que as frações protéicas $2 S$ e $11 S$ não induziram a produção de anticorpos IgE nesse modelo experimental;

- Não foi possível detectar a presença de anticorpos lgE, dirigidos contra as frações protéicas $2 S, 7 S$ e $11 S$, no soro de pacientes alérgicos à soja, pelo teste de ELISA;

- Os anticorpos monoclonais denominados de 1H4, 2A8, 1F9 (anti 7S) e 3F2 (anti 11S) foram altamente reativos às respectivas frações protéicas da soja;

- Os anticorpos monoclonais dirigidos contra as frações $7 S$ e $11 S$ da soja, podem ser utilizados para a detecção dessas proteínas em produtos comercializados, utilizando-se imunoensaio 


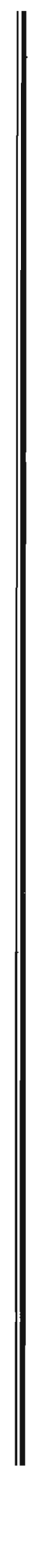




\subsection{RESUMO}

O objetivo deste trabalho foi esclarecer qual das fraçôes protéicas da soja é mais alergênica, avaliando-se sua imunogenicidade e alergenicidade por imunoensaios e teste de anafilaxia cutânea passiva. Além desse propósito, este estudo visou a produção de anticorpos monoclonais para utilizá-lo como ferramenta na padronização de um ensaio imunoenzimático com a finalidade de detectar proteínas da soja, em produtos comercializados. A purificação das frações $2 S$, $7 S$ e $11 \mathrm{~S}$ da soja foi realizada com base em estudos prévios, padronizando-se a metodologia dentro das condições experimentais do laboratório. A constatação da pureza foi realizada por eletroforese em gel de poliacrilamida (gel de empilhamento a $5 \%$ e de separação em gradiente de 7 a $15 \%$ ), onde se verificou as bandas protéicas características de cada fração. Evidenciou-se as subunidades $\alpha(63,17 \mathrm{KDa}) \alpha^{\prime}(58,06 \mathrm{KDa})$ e $\beta(42,09 \mathrm{KDa})$, correspondentes à fração $7 \mathrm{~S}$ da soja e as subunidades ácida $(38,8 \mathrm{KDa})$ e básica $(21,04 \mathrm{KDa})$, correspondentes à fração $11 S$ da soja. A fração $2 S$ da soja mostrou uma banda protéica de $20 \mathrm{KDa}$, nesse ensaio. Os resultados da cinética demonstraram que as frações $7 \mathrm{~S}$ e $11 \mathrm{~S}$ da soja são muito imunogênicas, visto que induziram uma grande produção de anticorpos das classes IgM e IgG, em camundongos BALB/C. Por outro lado, a fração $2 S$ da soja induziu uma pequena produção de anticorpos IgG, principalmente no $30^{\circ}$ dia após a imunização. No teste de anafilaxia cutânea passiva, quando se avaliou a capacidade das frações protéicas da soja de induzirem a produção de anticorpos $\mathrm{lgE}$, em camundongos $\mathrm{BALB} / \mathrm{c}$, verificou-se 
que a fração 75 da soja é alergênica, nesse modelo experimental. Entretanto, as frações 2S e 11S não estimularam o sistema imunológico desses animais a produzir essa classe de anticorpo. Quando se investigou a presença de anticorpos $\lg E$ dirigidos contra as frações protéicas $2 S, 7 S$ e $11 S$ da soja, no soro de pacientes alérgicos, obteve-se resultado negativo com todas as três proteínas estudadas. Entretanto, na análise da presença de lgG, tanto o soro dos pacientes alérgicos como o dos controles mostraram-se reativos às frações $2 S$ e $7 S$ da soja, sugerindo a presença do anticorpo $\operatorname{lgG} 4$ anafilático no soro teste. Os quatro anticorpos monoclonais reativos às frações 75 e $11 S$ da soja, obtidos neste estudo, mostraram-se reativos até as diluições 1/8000 (2A8 e 1H4) e 1/10000 (1F9) para a fração $7 S$ e 1/12000 (3F2) para a fração 11S da soja. A identificação dos determinantes antigênicos reconihecidos pelos anticorpos monoclonais foi realizado por Imunotransferência. Observou-se que os anticorpos monoclonais anti-fração protéica 7S da soja (1H4, 2A8 e 1F9) reconheceram as subunidades $\alpha$, $\alpha^{\prime}$ e $\beta(1 F 9)$, $\alpha^{\prime}$ e $\beta(1 \mathrm{H} 4)$ e $\beta(2 \mathrm{~A} 8)$, além de outras proteínas. Por ouro lado, o anticorpo monoclonal anti-fração protéica $11 \mathrm{~S}$ da soja (3F2) reagiu apenas com a subunidade básica dessa proteína. A padronização do ensaio imunoenzimático com o objetivo de detectar proteínas de soja, em produtos comercializados, mostrou que os anticorpos monoclonais dirigidos contra as frações protéicas 75 e $11 \mathrm{~S}$ reconhecem, apenas, as proteínas da soja. Em conclusão, esses resultados sugerem que as frações protéicas $7 S$ e $11 S$ da soja são imunogênicas em camundongos, enquanto que na espécie humana, essa resposta foi observada 
com as frações $2 S$ e $7 S$ da soja. No teste de anafilaxia cutânea passiva, a fração protéica 7S da soja mostrou a capacidade de induzir anticorpos da classe IgE em camundongos BALB/c, sugerindo que essa fração é alergênica nesse ensaio. Por outro lado, os anticorpos monoclonais reativos às frações $7 \mathrm{~S}$ e $11 \mathrm{~S}$ detectaram as proteínas da soja nos produtos comercializados testados. 


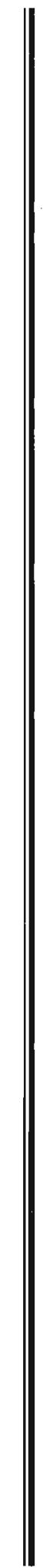

9.0 Abstract 


\subsection{ABSTRACT}

The goal of this study was to elucidate which of the soy protein fractions is more allergenic by using enzyme immunoassays and passive cutaneous anaphylactic activity test. Furthermore, monoclonal antibodies were obtained in order to standardize immunoassays to detect soy protein fractions in commercial soyderived products. Purification of $2 S, 7 S$ and $11 S$ fractions from soy was based on previous studies which were adapted to our experimental conditions. Purity of the isolated fractions was determined by polyacrilamide gel electrophoresis $(7-15 \%)$. The subunits $\alpha(63,17 \mathrm{KDa}) \alpha^{\prime}(58,06 \mathrm{KDa})$ and $\beta(42,09 \mathrm{KDa})$, corresponding to $7 \mathrm{~S}$ fraction as well as the acid $(38,8 \mathrm{KDa})$ and basic $(21,04 \mathrm{Kda})$ subunits of $11 \mathrm{~S}$ fraction were visualized. The $2 \mathrm{~S}$ fraction showed a $20 \mathrm{KDa}$ band only. Data showed that the $7 \mathrm{~S}$ and $11 \mathrm{~S}$ soy fractions are immunogenic as they elicited $\operatorname{lgM}$ and IgG antibodies in $B A L B / C$ mice. In contrast, the $2 S$ fraction was not immunogenic in this specie. The passive cutaneous anaphylactic activity test showed that 7S fraction is allergenic as it elicited $\operatorname{lgE}$ production in BALC mice. However, this test was negative for $2 S$ and $7 S$ fractions. No $\lg E$ reactive against the $2 S, 7 S$ e $11 S$ was found in sera of patients $(n=5)$ presenting previous food allergy symptoms. However, either these patients or controls $(n=5)$ showed IgG reactive against $2 S$ and $7 S$ fractions in their sera. The four monoclonal antibodies obtained in this study were reactive up to $1 / 8000$ (2A8 and $1 \mathrm{H} 4)$ and $1 / 10000$ (1F9) against $7 S$ fraction, and up to $1 / 12000$ (3F2) for 11 S fraction. Immunoblot analysis showed that the monoclonal antibodies anti-7S fraction (1H4, $2 \mathrm{A8}$ e 1F9) 
recognized the $\alpha, \alpha^{\prime}$ and $\beta(1 F 9), \quad \alpha^{\prime}$ and $\beta(1 H 4)$ and $\beta(2 A 8)$ subunits. The monoclonal antibody anti-11S fraction (3F2) reacted with the basic subunit of this fraction only. By using ELISA and the monoclonal antibodies anti-7S and anti-11S it was possible to detect especifically these soy protein fractions in commercial soy-derived products. In conclusion, data suggest that $7 S$ and $11 S$ soy protein fractions are immunogenic in mice while $2 S$ and $7 S$ fraction are immunogenic in humans. The $\mathrm{IgE}$ response to $7 \mathrm{~S}$ fraction in BALB/C mice showed by the passive cutaneous anaphylactic activity test indicates that this soy protein fraction is allergenic in this experimental model. Finally, the monoclonal antibodies anti-7S and anti-11S obtained in this study did not react with other vegetable or animal proteins being suitable to be used in ELISA for detection of these proteins in commercial soy-derived products. 


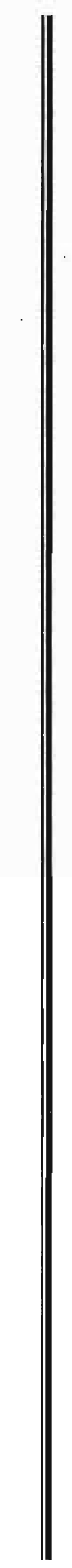

10.0 Referências Bibliográficas 


\subsection{REFERÊNCIAS BIBLIOGRÁFICAS}

AAS, K.; ELSAYED, S.M. Characterization of a major allergen. Effect of enzymic hydrolysis on the allergenic activity. J. Allergy, 44: 333, 1969.

ALLEN, A.L.; KOLLER, L.D.; POLLOCK, G.A. Effect of toxaphene exposure on immune responses in mice. J. Toxicol. Environ. Health, 11: 61, 1982.

ABBAS, A.B.; LICHTMAN, A.H.; POBER, J.S. Immediate Hypersensitivity In: Cellular and Molecular Immunology. WB Saunders Company, Philadelphia, Pennsylvania, pp.424, 2000.

ABBAS, A.K.; MURPHY, K.M.; SHER, A. Functional diversity of helper T lymphocytes. Nature, 383: 787, 1996.

ARRESE, E.L.; SORGENTINI, D.A.; WAGNER, J.R.; AÑÓN, M.C. Electrophoretic, solubility and functional properties of commercial soy protein isolates. J. Agric. Food Chem. 39: 1029, 1991.

AWAZUHARA, $\mathrm{H}_{.}$; KAWAI, H.; MARUCHI, N. Major allergens in soybean and clinical significance of IgG4 antibodies investigated by $\lg E$ and IgG4immunoblotting with será from soybean-sensitive patients. Clin. and Exp. Allergy, 27: 325, 1997.

AWAZUHARA, H.; KAWAI, H.; BABA, M.; MATSUI, T.; KOMIYAMA, A. Antigenicity of the proteins in soy lecithin and soy oil in soybean allergy. Clin. Exp. Allergy, 28 (12): 1559, 1998.

BARDARE, M.; VACCARI, A.; ALLIEVI, E. Influence of dietary manipulation on incidence of atopic disease in infant at risk. Ann. Allergy, 71: 366, 1993.

BISHOP, J.M.; HILL, D.J.; HOSKING, C.S. Natural history of cow's milk allergy: clinical outcome. J. Pediatr., 116: 862, 1990. 
BOCK, S.A. Prospective appraisal of complaints of adverse reactions to foods in children during the first 3 years of life. Pediatrics, 79:683, 1987.

BOCK, S.A.; ATKINS, F.M. Patterns of food hypersensitivity during sixteen years of double-blind, placebp-controlled food challenges. J. Pediatr. 117: 561, 1990.

BROOKS, J.R.; MORR, C.V. Current aspects of soy protein fractionation and nomenclature. J. Am. Oil Chem. Soc., 62: 1347, 1985.

BRUNO, G.; GIAMPIETRO, P.G.; DEL GUERCIO, M.J. ET AL. Soy allergy is not common in atopic children: a multicenter study. Pediatr. Allergy Immunol., 8 : $190,1997$.

BRUNO, G.; MILITA, O.; FERRARA, M.; NISINI, R.; CANTANI, A.; BUSINCO, L. Prevention of atopic diseases in high risk babies (long-term follow-up). Allergy Proc., 14: 181, 1993.

BURKS, A.W; BROOKS, J.R.; SAMPSON, H.A. Allergenicity of major component proteins of soybean determined by enzyme-linked immunosorbent assay (ELISA) and immunoblotting in children with atopic dermatitis and positive soy challenges. J. Allergy Clin. Immunol., 81: 1135, 1988.

BURKS, A.W.; CASTEEL, H.B.; FIEDOREK, S.C.; WILLIAMS, L.W.; CONNAUGHTON, C.; BROOKS, J.R. Enzyme-linked imunosorbent assay and Immunoblotting determination of antibody response to major component proteins of soybeans in patients with soy protein intolerance. J. Pedriatr. Gastroenterol. Nutr., 8:195, 1989.

BURKS, A.W.; CASTEEL, H.B.; FIEDOREK, S.C.; WILLIAMS, L.W.; PLUMPHREY, C.L. Prospective oral food challenge study of two soybean protein isolates in patients with possible milk or soy protein enterocolitis. Pediatr. Allergy Immunol., 5: 40, 1994. 
BURKS, A.W.; WILLIAMS, L.W.; HELM, R.M.; THRESHER, W.; BROOKS, J.R.; SAMPSON, H.A. Identification of soy protein allergens in patients with atopic dermatitis and positive soy challenges; determination of change in allergenicity after heating or enzyme digestion. In: Nutritional and Toxicological Consequences of Food Processing, Friedman, M. Ed., Plenum Press, New York, 295, 1991a.

BURKS, A.W.; WILLIAMS, L.W; CONNAUGHTON, C.; COCKRELL, G.; O'BRIEN, T.J.; HELM, R.M. Identification and characterization of a second major peanut allergen, Ara h 2, with use of the sera of patients with atopic dermatitis and positive peanut challenge. J. Allergy Clin. Immunol., 90: 962, 1992.

BURKS, A.W.; WILLIAMS, L.W; HELM, R.M.; CONNAUGHTON, C.; COCKRELL, G.; O'BRIEN, T.J. Identification of a major peanut allergen, Ara $h 1$, in patients with atopic dermatitis and positive peanut challenges. J. Allergy Clin. Immunol. 88: 712, $1991 \mathrm{~b}$.

BUSINCO, L. Hypoallergenic formulae: what's in the name? Eur. J. Paediatr., 153: $391,1994$.

BUSINCO, L.; CANTANI, A. Prevention of childhood allergy by dietary manipulation. Clin. Exp. Allergy, 20: 9, 1990.

BUSINCO, L.; BRUNO, G.; GIAMPIETRO, P.G.; CANTANI, A. Allergenicity and nutritional adequacy of soy protein formulas. The J. of Pediatr., S21, 1992.

BUSINCO, L.; BRUNO, G.; GIAMPIETRO, P.G; FERRARA, M. Is prevention of food allergy worthwhile. J. Invest. Allergol. Immunol. (Madr), 3: 231, 1993.

BUSINCO, L.; BRUNO, G.; GRANDOLFO, M.G.; NOVELLO, F.; FIORE, L.; AMATO, C. Response to poliovirus immunization and type of feedind in babies of atopic families. Pediatr. Allergy Immunol., 1: 60, 1990. 
CANTANI, A.; BUSINCO, L. Whey protein hydrolysate formula for infants with gastrointestinal intolerance to cow milk and soy protein formula. J. Pediatr. Gastroenterol. Nutr. 13: 315, 1991.

CANTANI, A.; FERRARA, M.; RAGNO, V.; BUSINCO, L. Efficacy and safety of a soy protein formula for feeding babies with atopic dermatitis and cow's milk hypersensitivity. Riv. Eur. Sci. Med. Farmacol. 12: 311, 1990.

CARVALHO, F.A. Diagnóstico laboratorial da alergia alimentar. NewsLab, ed. 26 : $139,1998$.

CATSIMPOLAS, N.; EKENSTAM, C. Isolation of alpha, beta and gamma conglycinins. Arch. Biochem. Biophys., 129: 490, 1969.

CHATCHATEE, P.; JÄRVINEN, KM; BARDINA, L.; VILA, L.; BEYER, K.; SAMPSON, H.A. Identification of $\operatorname{lgE}$ and $\lg \mathrm{G}$ binding epitopes on beta and kappa casein in cow's milk allergic patients. Clin. Exp. Allergy, 31 (8): 1256, 2001

CODINA, R.; OEHLING, Jr A.G.; LOCKEY, R.F. Neoallergens in heated soybean hull. Int. Arch. Allergy Immunol. 117 (2): 120, 1998.

COFFMAN, R.L.; CARTY, J. A T cell activity that enhances polyclonal IgE production and its inhibition by interferon - $\gamma$. J. Immunol., 136: 949, 1986.

COOK, J.A.; MARCONI, E.A.; DILUZIO, N.R. Lead, Cadmium, endotoxin interaction: effect on mortality and hepatic function. Toxicol. Appl. Pharmacol. 28: $292,1974$.

CORRY, D.B.; KHERADMAND, F. Induction and regulation of the IgE response. Nature, 402 (supp), B18, 1999. 
DEAN, J.H.; PADARATHSINGH, M.L.; JERELLS, T.R.; KEYS, L.; NORTHING, J.W.. Assessment of immunobiological effects induced by chemicals, drugs, or food additives. II studies with cyclophosphamide. Drug Chem. Toxicol. 2: $133,1979$.

DEARMAN, R.J.; KIMBER, I. Determination of protein allergenicity: studies in mice. Toxicolo. Lett., $120(1-3):$ 181, 2001.

DE VRIES, J.E. Novel fundamental approaches to intervening in lgE-mediated allergic diseases. J. Invest. Dermatol., 102: 141, 1994.

FERLIN, W.G.; SEVERINSON, E.; STRÜM, L.; HEATH, A.W.; COFFMAN, R.L.; FERRICK, D.A.; HOWARD, M.C. CD40 signaling induces interleukin-4independent IgE switching in vivo. Eur. J. Immunol. 26: 2911, 1996.

FURMONAVICIENE, R.; SHAKIB, F. The molecular basis of allergenicity: comparative analysis of the three dimensional structures of diverse allergens reveals a common structural motif. Mol. Pathol. 54 (3): 155, 2001.

GARCIA, M.C; TORRE, M.; MARINA, M.L.; LABORDA, F. Composition and characterization of soybean and related products. Crit. Rev. in Food Sci. and Nutr. 37 (4): 361, 1997.

GIAMPIETRO, P.G.; RAGNO, V.; DANIELE, S.; CANTANI, A.; FERRARA, M.; BUSINCO, L. Soy hypersensivity in children with food allergy. Annals of Allergy, 69: 143, 1992.

HARIKUL, S.; HARUEHASAVASIN, Y.; VARAVITHYA, W.; CHAICUMPA, W. CoW milk protein allergy during the first year of life: a 12 year experience at the children's hospital, Bangkok. Asian Pac. J. Allergy Immunol., 13: 107, 1995.

HERIAN, A.M.; TAYLOR, S.L.; BUSH, R.K. Identification of soybean allergens by immunoblotting with sera from soy-allergic adults. Int. Arch. Allergy Appl. Immunol. 92:193, 1990. 
HILL, L.; STUART, H. Soybean food preparation for feeding infants with milk idiosyncrasy. JAMA, 93: 985, 1929.

HINTON, D.E.; LIPSKY, M.M.; HEATFIELD, B.M.; TRUMP, B.F. Oposite effects of lead on chemical carcinogenesis in kidney and liver of rats. Bull. Environ. Contam. Toxicol. 23: 464, 1979.

HOU, J.; SCHINDLER, U.; HENZEL, W.J.; HO, T.C.; BRASSEUR, M.; Mc KNIGHT, S.L. An interleukin-4 induced transcription factor: IL-4 Stat. Science, 265: 1701, 1994.

HOUSE, R.V. Cytokine measurement techniques for assessing hypersensitivity. Toxicol. 158: 51, 2001.

HUGUES, M.; BOIVIN, P.; GAUILLARD, F.; NICOLAS, J.; THIRY, J.M.; RICHARDGORGET, F. Two lipoxygenases from germinated barley-heat and kilning stability. J. Food Sci., 59: 885, 1994.

ICIEK, L.A.; DELPHIN, S.A.; STAVNEZER, J. CD40 cross-linking induces Ig epsilon germline transcripts in B cells via activation of NF-kappa B: synergy with IL-4 induction. J. Immunol., 158: 4769, 1997.

ISHII, T.; YAMAGUCHO, M. Nutritive value of soy milk protein and hypocholesterolemic effect of soy milk in growing rats. Eiyogaku Zasshi, 50: 347, 1992.

JAKOBSSON, I.; LINDBERG, R. A prospective study of cow's milk protein intolerance in Swedish infants. Acta Paediatr. Scand., 68: 853, 1979.

JUTO, P.; ENGBERG, S.; WINBERG, J. Treatment of infantile atopic dermatitis with a strict elimination diet. Clin Allergy, 8: 493, 1978.

KAWABE, T.; NAKA, T.; YOSHIDA, K.; TANAKA, T.; FUJIWARA, H.; SUEMATSU, S.; YOSHIDA, N.; KISHIMOTO, T.; KIKUTANI, H. The immune responses in 
CD40-deficient mice impaired immunoglobulin class switching and germinal center formation. Immunity, 1: 167, 1994.

KEETON, J.T. Altering fat composition of red meat and fish products. In: Food, Fats and Health. Council for Agricultural Science and Technology (CAST), Task Force Report no 118: 42, 1991.

KERKVLIET, N.I.; KIMELDORF, D.J. Antitumor activity of a polychlorinated biphenyl mixture Aroctor 1254, in rats inoculate with Walker 256 carcinoma cells. J. Natl. Cancer Inst. 69: 951, 1977.

KERKVLIET, N.I.; BEACHER-STEPPAN, L.; CLAYCOMB, A.T.; CRAIG, A.M.; SHEGGEBY, G.G. Immunotoxicity of technical pentachlorophenol PCP-T; depressed hormonal immune responses to $T$-dependent and $T$-independent antigen stimulation in PCP-T exposed mice. Fund. Appl. Toxicol., 2: 90, 1982.

KIMBER, I.; LUMLEY, C.E.; METCALFE, D.D. Allergenicity of proteins. Human \& Exp. Toxicol., 16: 516, 1997.

KING, T.P.; HOFFMAN, D.; LOWENSTEIN, H.; MARSH, D.G.; PLATTS-MILLS, T.A.; THOMAS, W. Allergen nomenclature. Allergy, 50: 765, 1995.

KOLLER, L.D.; EXON, J.H.; ROAN, J.G. Humoral antibody response in mice after single dose exposure to lead or cadmium. Proc. Soc. Exp. Biol. Med. 151: 339,1976

KOLLER, L.D.; EXON, J.H; MOORE, S.A.; WATANABE, P.G. Evaluation of ELISA for detecting in vivo chemical immunomodulation. J. Toxicol. Environ. Health, 11: 15, 1982.

KOLLER, L.D. A perspective on the progression of immunotoxicology. Toxicol., 160: 105, 2001. 
KUITUNEN, P.; VISAKORPI, J.K.; SAVILAHTI, E.; PELKONEN, P. Malabsorption syndrome with cow's milk intolerance. Clin. findings and course in 54 cases. Arch Dis Child, 50 (5): 351, 1975.

KOHLER L.; MEEUWISSE, G.; MORTENSSON, W. Food intake and growth of infants between six and twenty-six weeks of age on breast milk, cow'smilk formula, or soy formula. Acta Paediatr Scand., 73: 40, 1984.

KOSHIYAMA, I.; IGUCHI, N. Agr. Biol. Chem. 29: 144, 1965.

KOSHIYMA, I.; Cereal Chem. 45: 394, 1968.

LACK, G.; RENZ, H.; SALOGA, J.; BRADLEY, KL; LOADER, J.; LEUNG, D.Y.; LARSEN, G.; GELFAND, E.W. Nebulized but not parenteral IFN-gamma decreases IgE production and normalizes airways function in a murine model of allergen sensitization. J. Immunol., 152 (5): 2546, 1994.

LAWRENCE, D.A.; EASTMAN, A.; WEIGLE, W.O. Murine T-cell preparations: radiosensitivity of helper activity. Cell. Immunol. 36: 97, 1978.

LEHRER, S.B.; HORNER, W.E.; REESE, G. Why are some proteins allergenic? Implications for biotechnology., Crit. Rev. Food Sci Nutr. 36 (6): 553, 1996.

LIENER, I.E.; Implications of antinutritional components in soybean foods. Crit. Rev. Food Sci. Nutr. 34 (1): 31, 1994.

LINEHAN, L.A.; WARREN, W.D.; THOMPSON, P.A.; GRUSBY, M.J.; BERTON, M.T. STAT6 is required for IL-4 induced germline $\lg$ gene transcription and switch recombination. J. Immunol., 161: 302, 1998.

LOCKSLEY, R.M. Th2 cell: help for helminthes. J. Exp. Med. 179: 1405, 1994.

LUSTER, M.I.; FAITH, R.E.; KIMMEL, C.A. Depression of humoral immunity in rats following chronic developmental lead exposure. J. Env. Path. Toxicol., 1: 397, 1978. 
MAY, C.D.; REMIGIO, L.; BOCK, S.A. Usefulness of measurement of antibodies in serum in diagnosis of sensitivity to cow's milk and soy proteins in early childhood. Allergy, 35: 301, 1980.

METCALFE, D.D.; ASTWOOD, J.D.; TOWNSEND, R.; SAMPSON, H.A.; TAYLOR, B.L.; FUCHS, R.L. Assessment of the allergenic potential of foods derived from genetically engineered crop plants, Crit. Rev. Food Sci. Nutr., 36: S165, 1998.

MOORE, J.A.; FAITH, R.E. Immunological response and factors effecting its assessment. Environ. Health Perspect., 18: 125, 1976.

MOROI, T. Correlation of specific IgG4 antibody titers and specific IgE RAST score to egg white, milk and soybean in allergic children. Jpn J. Allergol., 37: 331 , 1988.

MOTA, I.; WONG, D. Homologous and heterologous passive cutaneous anaphylactic activity of mouse antisera during the course of immunization. Life Sci., 8: 813, 1969.

MURRAY, K.; CHRISTIE, D. Dietary protein intolerance in infants with transient methemoglobinemia and diarrhea. J. Pediatr., 122: 90, 1993.

NAIDOO, B.T.; CHUNTERPURSHAD, B.T.; MAYOODEN, A.B.G. The use of a soy isolate based formula in the treatment of infantile diarmea. J. Int. Med. Res., 9: $232,1981$.

NAKAGAWA, T. The role of IgG subclass antibodies in the clinical response to immunotherapy in allergic disease. Clin. Exp. Allergy, 21: 289, 1991.

NAKANISHI, K.; YOSHIMOTO, T.; CHU, C.C.; MATSUMOTO, H.; HASE, K.; NAGAI, N.; TANAKA, T.; MIYASAKA, M.; POUL, W.E.; SHINKA, S. IL-2 inhibits $\mathrm{IL}-4$ dependent $\lg$ and $\lg \mathrm{G} 1$ production in vitro and in vivo. Int. Immunol. 7: 259, 1995. 
NORDLEE, J.A.; TAYLOR, S.L.; JEFFREY, A.; TOWNSEND, B.S.; LAURIE, A.; THOMAS, B.S.; BUSH, R.K. Identification of Brazil-nut allergen in transgenic soybeans. New Engl. J. 334: 688, 1998.

OGAWA, T.; BANDO, N.; TSUJI, H.; OKAJIMA, H.; NISHIKAWA, K.; SASOKA, K. Investigation of the IgE-binding proteins in soybeans by immunobblotting with the sera of soybean-sensitive patients with atopic dermatitis. J. Nutr. Sci. Vitaminol, 37: 555, 1991.

OGAWA, A.; SAMOTO, M.; TAKAHASHI, K. Soybean allergens and hypoallergenic soybean products. J. Nutr. Sci. Vitaminol. (Tokyo) 46 (6): 271, 2000.

PARISH, W.E. The clinic relevance of heat-stable, short-term sensitizing anaphylactic IgG antibodies (IgG S-TS) and of related activities of IgG4 and IgG2. Br. J. Dermatol. 105: 223, 1981.

PARNELL, M.J.; KOLLER, L.D.; EXON, J.H.; ARNZEN, J.M. Trichloroacetic acid effects on rat liver peroxisomes and enzyme-altered foci. Environ. Health Perspect. 69: 73, 1986.

PARRONCHI, P.; MACCHIA, D.; PICCINNI, M.P.; BISWAS, P.; SIMONELLI, C.; MAGGI, E.; RICCI, M.; ANSARI, A.A.; ROMAGNANI, S. Allergen and bacterial antigen-specific T-cell clones estabilished from atopic donors show a different profile of cytokines production. Proc. Natl. Acad. Sci. USA 88: 4538, 1991.

PASCHKE, A.; ZUNKER, K.; WIGOTZKI, M.; STEINHART, H. Determination of the lgE-binding activity of soy lecithin and refined and non-refined soybean oils. J. of Chromatography B, 756: 249, 2001.

PAHUD, J.J.; SCHWARZ, K.; GRANATO, D. Control of hypoallergenicity by animal models. In: Reinhardt, D.; Schmidt, E. eds. Food Allergy. Nestlé Nutrition Series. Vol. 17, New York: Raven Press, pp 199, 1988. 
PENE, J.; ROUSSET, F.; BRI ERE F.; CHRÉTIEN, I.; BONNEFOY, J.Y.; SPITS, H.; YOKOTA, T.; ARAI, N.; BANCHEREAUT, J. IgE production by normal human lymphocytes is induced by interleukin 4 and suppressed by interferon $\alpha, \gamma$ and prostaglandin $E_{2}$. Proc. Natl. Acad. Sci. USA, 85 (18): 6880, 1988.

PIACENTINI, G.L.; BENEDETTI, M.; SPEZIA, E. ET AL Anaphylactic sensitizing power of selected infant formulas. Ann. Allergy, 167: 400, 1991.

POWELL, G.K. Milk and soy-induced enterocolits of infancy. J. Pediatr., 93 (4): 553,1978 .

RAGNO, V.; GIAMPIETRO, P.G.; BRUNO, G.; BUSINCO, L. Allergenicity of milk protein hydrolysate formulae in children with cow's milk allergy. Eur. J. Pediatr., 152: 760, 1993.

RING, J.; BROCKOW, K.; BEHRENDT, H. Adverse reactions to foods, J. Chromatog. B, 756: 3, 2001.

RIPPE, D.F.; BERRY, L.J. Metabolic manifestations of lead acetate sensitization to endotoxin in mice. J. Reticuloendoth. Soc. 13: 527, 1973.

ROBINSON, D.S.; HAMID, Q.; YING, S.; TSICOPOULOS, A.; BARKANS, J.; BENTLEY, A.M.; CORRIGAN, C.; DURHAM, S.R.; KAY, A.B. Predominant Th2-like bronchoalveolar T-lymphocyte population in atopic asthma. N. Engl. J. Med. 326 (5): 298, 1992.

ROMAGNANI, S. Lymphokine production by human $\mathrm{T}$ cells in disease states. Annu. Rev. Immunol., 12: 227, 1994.

SABIN, E.A.; KOPF, M.A.; PEARCE, E.J. Schistosoma mansoni eggs-induced early IL-4 production is dependent upon IL-5 and eosinophilis. J. Exp. Med. 184: 1871, 1996. 
SAMPSON, H.A.; ALBERGO, R. Comparison of results of skin tests RAST and doublé-blind placebo-controled food challenges in children with atopic dermatitis. J. Allergy Clin. Immunol. 74: 26, 1984.

SAMPSON, H.A. Food allergy. Part 1: immunopathogenesis and clinical disorders. J. Allergy Clin. Immunol., 103: 717, 1999.

SAMPSON, H.A. Pathogenesis of eczema. Clin. Exp. Allergy, 20: 459, 1990.

SAMPSON, H.A. The role of food hypersensitivity and mediator release in atopic dermatitis. J. Allergy Clin. Immunol., 81: 635, 1988.

SAMPSON, H.A.; MCCASKILL, C.C. Food hypersensitivity and atopic dermatitis: evaluation of 113 patients. J. Pediatr. 107: 669, 1985.

SAMPSON, H.A. Legumes, eggs and milk. Allergy, 53 (Suppl 46): 38, 1998.

SAVELKOUL, F.H.M.G.; BOER, H.; TAMMINGA, S.; SCHEPERS, A.J.; ELBURG, L. In vitro enzymatic hydrolysis of protein and protein pattem change of soya and faba beans during germination. Plant Foods Hum. Nutr., 42: 275, 1992.

SELYE, H.; TUCHWEVER, B.; BERTOK, L. Effect of lead acetate on the susceptibility of rats to bacterial endotoxins. J. Bact., 91: 884, 1966.

SCHWARTZ, R.H. Costimulation of T lymphocytes the role of CD28, CTLA-4 and B7/BB1 in interleukin-2 production and immunotherapy. Cell, 71: 1065, 1992.

SHIBASAKI, M.; SUZUKI, S.; TAJIMA, S.; NEMOTO, H.; KUROUME, T. Allergenicity of major component proteins of soybean. Int. Arch. Allergy Appl. Immunol., 61: 441, 1980.

SICHERER, S.H. Food allergy: When and how to perform oral food challenges. Pediatr. Allergy and Immunology, 10 (4): 226, 1999.

SICHERER, S.H. Food protein-induced enterocolitis syndrome: clinical perspective. J. Pediatr. Gastroenterol. Nutr., 30 (Suppl): \$45, 2000. 
SICHERER, S.H; S.H.; EIGENMANN, P.A.; SAMPSON, H.A. Clinical features of food protein-induced enterocolitis syndrome. J. Pediatr. 133: 214, 1998.

SILKWORTH, J.B.; LOOSE, L.D. Cell-mediated immunity in mice fed either Aroclor 1016 or hexachlorobenzene. Toxicol. Appl. Pharmacol., 45: 326, 1978.

SNYDER, H.E.; KNOW, T.W. In: Soybean Utilization, pp 31-73, Avi Book, 1987.

STEICHEN, J.J.; TSANG, R.C. Bone mineralization and growth in term infants fed soy-based or cow milk-based formula. J. Pediatr., 110: 687, 1987.

STANWORTH, D.R.; SMITH, A.K. Human IgG subclass with primate skin binding activity. Lancet, 491, 1972.

STREET, J.C.; SHARMA, R.P. Alteration of induced cellular and humoral responses by pesticides and chemicals of environmental concem: quantitative studies of immuno-supression by DDT, Arcolor 1254, carbaryl, carbonfuran and methylparation. Toxicol. Appl. Pharmacol., 32: 587, 1975.

TADA, T.; OKUMURA, K.; PLATTEAU, B.; BECKERS, A.; BAZIN, H. Half-lives of two types of rat homocytotropic antibodies in circulation and in the skin. Int. Arch. Allergu Appl. Immunol. 48: 116, 1975.

TALCOTT, P.A.; EXON, J.H.; KOLLER, L.D. Alteration of natural killer cellmediated cytotoxicity in rats treated with selenium, diethyltirosomine and sthyInitrosourea. Cancer Lett., 23: 313, 1984.

TALCOTT, P.A.; EXON, J.H.; MATHER, G.G.; KOLLER, L.D. The effects of methylnitrosourea (MNU) on natural killer (NK) cell cytotoxicity and cytokine production in rats. Carcinogenesis, 11: 829, 1990.

THANH, V.H.; OKUBO, K.; SHIBASAKI, K. Isolation and characterization of the multiple 7 S globulins of soybean proteins. Plant Physiol., 56: 19, 1975. 
THANH, V.H.; SHIBASAKI, K. Major proteins of soybean seeds: A straightforward fracionation and their characterization. J. Agric. Food Chem. 24: 1117, 1976a.

THIGPEN, J.E.; FAITH, R.E.; MCCONNELL, E.E.; MOORE, J.A. Increased susceptibility to bacterial infection as a sequela to exposure of $2,3,7,8$ Tetrachlorodibenzo-p-dioxin. Infect. Immune, 12: 1319, 1975.

TRUSCOTT, R.B. Endotoxin studies in chicks: effects of lead acetate. Can. J. Comp. Med., 34: 134, 1970.

VAN DER ZEE, J.S.; VAN SWIETEN, P.; AALBERSE, R.C. Inhibition of complement activation by IgG4 antibodies. Clin. Exp. Immunol., 64: 415, 1986.

VAN SICKLE, G.J.; POWELL, G.K.; McDONALD, P.J.; GOLDBLUM, R.M. Milk and soy protein-induced enterocolitis: evidence for lymphocyte sensitization to specific food proteins. Gastroenterol., 88: 1915, 1985.

WARREN, W.D.; ROBERTS, K.L.; LINEHAN, L.A.; BERTON, M.T. Regulation of the germline immunoglobulin $\mathrm{C}$ gamma 1 promoter by CD40 ligand and IL-4: dual role for tandem NF-kappa B binding sites. Mol. Immunol. 36: 31, 1999.

WOLF, W.J.; BABCOCK, G.E.; SMITH, A.K. Purification and stability studies of the 11 s component of soybean proteins. Arch. Biochem. Biophys. 99: 265, 1962.

YAMAUCHI, F.; YAMAGISHI, T.; IWABUUCHI, S. Molecular understanding of heat-induced phenomena of soybean protein. Food Rev. Int., 7: 283, 1991.

YOKOTA, A.; KIKUTANI, H.; TANAKA, T.; SATO, R.; BARSUMIAN, E.L.; SUEMURA, M.; KISHIMOTO, T. Two species of human Fc epsilon receptor II (FC epsilon RII/CD23): tissue-specific and IL-4 specific regulation on gene expression. Cell, 55 (4): 611, 1988.

YOUNG, E.; STONEHAM, M.D.; PETRUCKEVITCH, A.; BARTON, J.; RONA, R. A population study of food intolerance. Lancet, 343: 1127, 1994. 
ZAR, S.; KUMAR, D.; BENSON, M.J. Food hypersensitivity and irritable bowel syndrome. Aliment. Pharmacol. Ther. 15 (4): 439, 2001.

ZEIGER, R.S.; SAMPSON, H.A.; BOCK, A.; BURKS, A.W.; HARDEN, K.; NOONE, S.; MARTIN, D.; LEUNG, S.; WILSON, G. Soy allergy in infants and children with IgE associated cow's milk allergy. J. Pediatric, 134 (5): 614, 1999.

ZOPPI, G.; GASPARI, R.; MANTOVANRILI, F. Diet and antibody response to vaccinations in healthy infants. Lancet, 2: 11, 1983. 


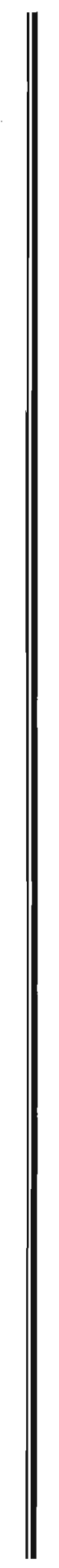

11.0 Anexos 
11.0 ANEXOS

11.1 Tabela de dados clínicos dos pacientes

\begin{tabular}{|c|c|c|c|c|c|c|}
\hline Pacientes" & $\begin{array}{l}\text { Idade } \\
\text { (anos) } \\
\text { sexo }\end{array}$ & $\begin{array}{l}\text { Dados } \\
\text { Clínicos }\end{array}$ & RAST" & Prick test & $\begin{array}{l}\text { Teste de } \\
\text { Provocação } \\
\text { Oral }\end{array}$ & $\begin{array}{c}\text { Conc. sérica } \\
\text { de IgE total } \\
\mathrm{U} / \mathrm{mL}\end{array}$ \\
\hline Teste 1 & $6 / M$ & $\begin{array}{c}\text { Alergia ao leite } \\
\text { de vaca } \\
\text { Alergia à soja }\end{array}$ & $\begin{array}{c}\text { Classe } 4 \text { ao } \\
\text { leite de vaca } \\
\text { e soja }\end{array}$ & - & - & $>4000$ \\
\hline Teste 2 & $2 M$ & $\begin{array}{c}\text { Alergia ao leite } \\
\text { de vaca }\end{array}$ & $\begin{array}{c}\text { Classe } 4 \text { ao } \\
\text { leite de vaca } \\
\text { Classe } 2 \text { à } \\
\text { soja }\end{array}$ & - & - & $>4000$ \\
\hline Teste 3 & $10 M$ & $\begin{array}{c}\text { Alergia ao leite } \\
\text { de vaca }\end{array}$ & - & - & $\begin{array}{l}\text { Positivo ao } \\
\text { leite de vaca }\end{array}$ & 295,8 \\
\hline Teste 4 & $2 / F$ & $\begin{array}{c}\text { Alergia ao leite } \\
\text { de vaca } \\
\text { Alergia à soja }\end{array}$ & - & - & $\begin{array}{c}\text { Positivo ao } \\
\text { leite de vaca } \\
\text { e soja }\end{array}$ & 56,4 \\
\hline Teste 5 & $20 / F$ & $\begin{array}{c}\text { Alergia ao leite } \\
\text { de vaca } \\
\text { Alergia à soja } \\
\text { Alergia às } \\
\text { carnes de } \\
\text { gado, porco e } \\
\text { aves }\end{array}$ & - & $\begin{array}{l}\text { Positivo ao } \\
\text { leite de vaca, } \\
\text { soja e carnes }\end{array}$ & - & 7,4 \\
\hline Controle 1 & $14 / F$ & $\begin{array}{l}\text { Asma } \\
\text { Rinite }\end{array}$ & - & $\begin{array}{c}\text { Zero para } \\
\text { leite de vaca } \\
\text { e soja }\end{array}$ & - & 790,4 \\
\hline Controle 2 & $8 / F$ & $\begin{array}{l}\text { Asma } \\
\text { Rinite }\end{array}$ & - & $\begin{array}{c}\text { Zero para } \\
\text { leite de vaca } \\
\text { e soja }\end{array}$ & - & 783,6 \\
\hline Controle 3 & $14 M$ & $\begin{array}{l}\text { Asma } \\
\text { Rinite }\end{array}$ & - & $\begin{array}{c}\text { Zero para } \\
\text { leite de vaca } \\
\text { e soja }\end{array}$ & - & 954,8 \\
\hline Controle 4 & $11 / F$ & $\begin{array}{l}\text { Asma } \\
\text { Rinite }\end{array}$ & - & $\begin{array}{c}\text { Zero para } \\
\text { leite de vaca } \\
\text { e soja }\end{array}$ & - & 797,4 \\
\hline Controle 5 & $45 / \mathrm{F}$ & Não alérgico & - & - & - & 54,0 \\
\hline
\end{tabular}

* Pacientes alérgicos à soja e controles

\# Critério para alergia alimentar - RAST > classe 3 ou classe 2 com anafilaxia (Instituto da Criança da Faculdade de Medicina da Universidade de São Paulo) 
11.2 Tabela de dados do teste de ELISA, investigando anticorpos IgG dirigidos contra as frações protéicas $2 S, 7 S$ e 11S da soja

\begin{tabular}{|c|c|c|c|}
\hline \multirow{2}{*}{ Pacientes* } & Fração 2S & \multicolumn{3}{|c|}{ Absorbâancia 7S a 405 nm } \\
\cline { 2 - 4 } & \multicolumn{3}{|c|}{ Fração 11S } \\
\hline Branco (média) & 0.088 & 0.110 & 0.066 \\
\hline Teste 1 & 1.447 & 1.458 & 1.612 \\
\hline Teste 2 & 0.558 & 0.597 & 0.410 \\
\hline Teste 3 & 0.632 & 0.520 & 0.058 \\
\hline Teste 4 & 0.322 & 0.500 & 0.021 \\
\hline Teste 5 & 1.051 & 0.897 & 0.688 \\
\hline Controle 1 & 1.093 & 0.871 & 0.462 \\
\hline Controle 2 & 0.750 & 0.816 & 0.186 \\
\hline Controle 3 & 1.484 & 0.894 & 0.611 \\
\hline Controle 4 & 1.247 & 1.032 & 0.370 \\
\hline Controle 5 & 0.851 & 0.761 & 0.106 \\
\hline
\end{tabular}

* Pacientes alérgicos à soja e controles 
11.3 Tabela de dados do teste de ELISA, investigando anticorpos IgE dirigidos contra as fraçōes protéicas 2S, 7S e 11S da soja

\begin{tabular}{|c|c|c|c|}
\hline \multirow{2}{*}{ Pacientes* } & Fração 2S & \multicolumn{2}{|c|}{ Absorbąncia a 405 nm } \\
\cline { 2 - 4 } & \multicolumn{3}{|c|}{ Fração 11S } \\
\hline Branco (média) & 0.131 & 0.231 & 0.121 \\
\hline Teste 1 & 0.155 & 0.185 & 0.147 \\
\hline Teste 2 & 0.127 & 0.187 & 0.116 \\
\hline Teste 3 & 0.124 & 0.182 & 0.111 \\
\hline Teste 4 & 0.146 & 0.170 & 0.129 \\
\hline Teste 5 & 0.134 & 0.115 & 0.130 \\
\hline Controle 1 & 0.120 & 0.199 & 0.211 \\
\hline Controle 2 & 0.133 & 0.107 & 0.125 \\
\hline Controle 3 & 0.122 & 0.189 & 0.121 \\
\hline Controle 4 & 0.127 & 0.185 & 0.118 \\
\hline Controle 5 & 0.126 & 0.156 & 0.120 \\
\hline
\end{tabular}

* Pacientes alérgicos à soja e controles 


\subsection{Soluçóes e reagentes utilizados}

\section{a) Etroforese em gel de poliacrilamida (SDS-PAGE)}

- Solução A (acrilamida $30 \%(\mathrm{p} / \mathrm{v})$, bis-acrilamida 0,8\% (p/v), água deionizada qsp $100 \mathrm{ml})$

- Solução B (tris base $1,5 \mathrm{M} \mathrm{pH} \mathrm{8,8,} \mathrm{SDS} 20 \%(\mathrm{p} / \mathrm{v}$ ), água deionizada qsp 100 $\mathrm{ml})$

- Solução C (tris base $0,5 \mathrm{M} \mathrm{pH} \mathrm{6,8,} \mathrm{SDS} 20 \%$ (p/v), água deionizada qsp 100 $\mathrm{ml)}$

- Tampão de eletroforese (Tris base 25 mM, Glicina $192 \mathrm{mM}$, SDS 0,1\% (p/v), água deionizada qsp $1000 \mathrm{ml}$ )

- SDS $20 \%$ (SDS [p/v], água qp $50 \mathrm{ml}$ )

- Persulfato de amônio 10\% (persulfato de amônio (p/v), água deionizada qsp 5 ml)

- Tampão de amostra (tris base $60 \mathrm{mM} \mathrm{pH} \mathrm{6,8,} \mathrm{glicerol} \mathrm{25 \% ,} \mathrm{SDS} \mathrm{2 \% ,} 2$ mercaptoetanol $14,4 \mathrm{mM}$, azul de bromofenol $0,1 \%$, água deionizada qsp 10 $\mathrm{ml)}$

- Gel de empilhamento $5 \%(0,067 \mathrm{ml}$ da solução A, $1 \mathrm{ml}$ da solução $C, 2,3 \mathrm{ml}$ de água deionizada, $10 \mu$ de temed, $30 \mu$ de persulfato de amônio)

- Gel de separação $7 \%$ (2,3 $\mathrm{ml}$ da solução $A, 2,5 \mathrm{ml}$ da solução $B, 5,2 \mathrm{ml}$ de água deionizada, $10 \mu$ de temed, $50 \mu$ de persulfato de amônio)

- Gel de separação $15 \%$ ( $5 \mathrm{ml}$ da solução A, 2,5 ml da solução B, 2,5 ml de água deionizada, $5 \mu$ de temed, $50 \mu$ de persulfato de amônio) 
- Solução fixadora (40 ml de metanol, $10 \mathrm{ml}$ ácido acético, água deionizada qsp $100 \mathrm{ml}$ )

- Coloração com comassie blue (1 g de comassie blue R-250, $450 \mathrm{ml}$ de metanol, $450 \mathrm{ml}$ de água deionizada, $100 \mathrm{ml}$ de ácido acético)

- Solução descorante (70 ml de ácido acético glacial, água deionizada qsp 1000 $\mathrm{ml)}$

b) Ensaio imunoenzimático (ELISA)

- Solução carbonato-bicarbonato $0,25 \mathrm{M}\left(\mathrm{Na}_{2} \mathrm{CO}_{3}-4,24 \mathrm{~g} ; \mathrm{NaHCO}_{3}-7,14 \mathrm{~g}\right.$, $\mathrm{pH}$ 9,6)

- Solução de PBS 10 vezes concentrado, $\mathrm{pH} 7,2\left(\mathrm{Na}_{2} \mathrm{HPO}_{4} .7 \mathrm{H}_{2} \mathrm{O}-80 \mathrm{mM}\right.$; $\left.\mathrm{KH}_{2} \mathrm{PO}_{4}-14 \mathrm{mM} ; \mathrm{NaCl}-1,36 \mathrm{M} ; \mathrm{KCl}-0,027 \mathrm{M}\right)$

- PBS + Tween 20 0,05\% (500 $\mu$ de Tween 20 em 1 litro de PBS pronto para uso)

- Leite desnatado a 5\% (5 g de leite desnatado qsp $100 \mathrm{ml}$ de tampão PBS)

- Solução de substrato e cromógeno para fosfatase $(1 \mathrm{mg} / \mathrm{ml}$ de paranitrofenilfosfato em tampão contendo glicina $0,1 \mathrm{M}, \mathrm{MgCl} 1 \mathrm{mM}$ e $\mathrm{ZnCl}_{2} 1$ $\mathrm{mM}, \mathrm{pH} 10,4)$

- Solução de substrato e cromógeno para peroxidase $(0,53 \mathrm{mg}$ de 2,2 azino bis (ácido 3 atilbenzotiazoline-6-sulfônico) - ABTS/ml de tampão citrato fosfato 0,1 M, pH 4,2 e 0,25 $\mu$ lde $\mathrm{H}_{2} \mathrm{O}_{2} / \mathrm{ml}$ de tampão)

- Adsorção de IgG (RF absorbent 1/2 com soro diluído 1/21) 


\section{c) Análise por Imunotransferência}

- Tampão de transferência (Tris 25 mM, glicina 0,192 M, metanol 20\%)

- Solução Tris-salina (Tris 0,01 M, NaCl 0,15 M, pH 7,5)

- Leite desnatado a $5 \%$ ( $5 \mathrm{~g}$ de leite desnatado qsp $100 \mathrm{ml}$ de tris salina)

- Solução de substrato e cromógeno para peroxidase [3 $\mathrm{ml}$ da solução estoque ( $30 \mathrm{~g}$ de $4 \alpha$ naftol diluído em $10 \mathrm{ml}$ de metanol), $17 \mathrm{ml}$ de tris salina e $20 \mu \mathrm{lde}$ $\left.\mathrm{H}_{2} \mathrm{O}_{2} \mathrm{~A} 30 \%\right]$

\section{d) Produção de anticorpos monoclonais}

- Meio RPMI+ ( Meio RPMI com L-glutamina $2 \mathrm{mM}$, piruvato de sódio $2 \mathrm{mM}$, aminoácidos essenciais $1 \mathrm{mM}$, gentamicina $0,01 \mathrm{mg} / \mathrm{ml}$, hepes $0,37 \mathrm{mM}$ e $10 \%$ de soro fetal)

- Meio RPMI- (Meio RPMI com L-glutamina $2 \mathrm{mM}$, piruvato de sódio $2 \mathrm{mM}$, aminoácidos essenciais $1 \mathrm{mM}$, gentamicina $0,01 \mathrm{mg} / \mathrm{ml}$, hepes $0,37 \mathrm{mM}$ )

- Polietileno glicol - (PEG) $[0,5 \mathrm{~g}$ de PEG, 0,7 $\mathrm{ml}$ de PBS pH 7,2 e $50 \mu \mathrm{lde}$ DMSO (Dimetil sulfóxido]

- Meio RPMI+ com HAT (histidina, aminopterina e timidina) [3 ml de HAT para $100 \mathrm{ml}$ de RPMI+]

- Meio RPMI+ com HT (histidina e timidina) [2 ml de HAT para $100 \mathrm{ml}$ de RPMl+]

- Solução carbonato-bicarbonato 0,25 M ( $\mathrm{Na}_{2} \mathrm{CO}_{3}-4,24 \mathrm{~g} ; \mathrm{NaHCO}_{3}-7,14 \mathrm{~g}$, $\mathrm{pH} 9,6)$

- Solução de PBS 10 vezes concentrado, $\mathrm{pH} 7,2\left(\mathrm{Na}_{2} \mathrm{HPO}_{4} .7 \mathrm{H}_{2} \mathrm{O}-80 \mathrm{mM}\right.$; $\left.\mathrm{KH}_{2} \mathrm{PO}_{4}-14 \mathrm{mM} ; \mathrm{NaCl}-1,36 \mathrm{M} ; \mathrm{KCl}-0,027 \mathrm{M}\right)$ 
- PBS + Tween $20(0,05 \%)(500 \mu l$ de Tween 20 em 1 litro de PBS pronto para uso)

- Solução de DMSO a 7,5\% (0,15 ml de DMSO + 0,85 ml de RPMl+)

- Tampão borato 0,1 M, pH 8,5 (ácido bórico 0,1 M, tetraborato de sódio 0,1 M, $\mathrm{NaCl} 0,15 \mathrm{M}$. Filtrar em filtro com 0,22 $\mu \mathrm{m})$

- Tampão borato-salina, $\mathrm{pH}$ 8,5 (950 $\mathrm{ml}$ de $\mathrm{NaCl}$ 0,15 M e $50 \mathrm{ml}$ de tampão borato, $0,1 \mathrm{M}, \mathrm{pH} 8,5$ )

- Tampão citrato, pH 5,0 (ácido cítrico 0,15 M, citrato de sódio 0,15 M. Acertar o $\mathrm{pH}$ com ácido cítrico)

- Tampão glicina, pH 2,8 (glicina 0,2 M e NaCl 0,15 M)

e) Extração e purificação da fração 75 da soja

Soluçóes utilizadas na eluição das proteinas de soja pela coluna de Concanavalina A Sepharose 4B

* Solução 1 (1ª eluição)

- $\quad$ Tris $\mathrm{HCl} 0,03 \mathrm{M}, \mathrm{pH} \mathrm{7,4}$

- Ditioeritritol (DTE) 0,001 M

- $\mathrm{NaCl} 0,4 \mathrm{M}$

* Solução 2 (2ª eluição)

- Tris HCl 0,03 M pH 7,4

- Ditioeritritol (DTE) 0,001 M

- $\mathrm{NaCl} 0,4 \mathrm{M}$

- $\quad \alpha$ MethyI D mannoside 0,1 M 